\title{
Türkiye'de Ortaöğretim Çağ Nüfusunun Okul Dışında Kalmasını Etkileyen Bireysel ve Sosyoekonomik Değişkenler*
}

\author{
Selman ALMIȘ ${ }^{* *} \quad$ Kasım KARAKÜTÜK ${ }^{* * *}$
}

- Geliş Tarihi: 14.12.2020 • Kabul Tarihi: 11.02.2021 • Çevrimiçi Yayın Tarihi: 11.02.2021

\section{$\ddot{\mathbf{O} z}$}

Bu araştırmada, Türkiye'de ortaöğretim çağ nüfusunun cinsiyete göre okul dışında kalmasını etkileyen bireysel ve sosyoekonomik değişkenleri belirlemek amaçlanmaktadır. Seçilen değişkenlerin etkisinin tarihsel süreçteki değişimini incelemek için Devlet İstatistik Enstitüsü’nün (DİE) 2003 yılında, Türkiye İstatistik Kurumu (TÜIK)'nun 2011 ve 2016 yıllarında yaptığı Hanehalkı Bütçe Anketlerindeki mikro veri setleri kullanılmıştır. Bağımlı değişken ikili ve kesikli olduğu için veriler Binary lojistik regresyon ile analiz edilmiştir. Araştırmada, modelin uyum iyiliği sözde $\mathrm{R}^{2}$ değeri aracılığıyla incelenmiş, bağımlı ve bağımsız değişkenler arasındaki ilişkinin gücünü ölçmek için Cox-Snell ve Nagelkerke $\mathrm{R}^{2}$ istatistikleri kullanılmıştır. Bağımsız değişkenlerin anlamlı yordayıcılar olduğu ve etki düzeylerinin yıllara göre farklılık gösterdiği belirlenmiştir. Ortaöğretim çağındaki erkeklerin okul dışında kalmasında engel durumu, sağlık güvencesi, anne ve baba eğitim düzeyi değişkenleri her üç yıla ait verilerde etkili yordayıcılar iken, yerleşim birimi 2011 verilerinde, hanehalkı büyüklügü 2016 verilerinde, kişibaşı yıllık gelir ise 2003 ve 2016 yılı verilerinde anlamlı yordayıcılar olarak saptanmıştır. Ortaöğretim çağındaki kızların okul dışında kalmasında engel durumu, yerleşim birimi, anne ve baba eğitim düzeyi, hanehalkı büyüklüğü değişkenleri her üç yıla ait verilerde etkili yordayıcılar iken, sağlık güvencesinin 2003 ve 2011 yılı verilerinde, kişibaşı yıllık gelirin ise 2003 ve 2016 yılı verilerinde anlamlı yordayıcılar olduğu ortaya çıkmıştır.

Anahtar sözcükler: okul dışında kalma, okul terk, eğitim hakk1, eğitime erişim, binary lojistik regresyon

Atıf:

Almış, S. ve Karakütük, K. (2021). Türkiye'de ortaöğretim çağ nüfusunun okul dışında kalmasını etkileyen bireysel ve sosyoekonomik değişkenler. Pamukkale Üniversitesi Eğitim Fakültesi Dergisi,53, 110-149. doi: 10.9779.pauefd.840809

\footnotetext{
* Bu çalışma, birinci yazarın "Ortaöğretim Düzeyindeki Çocukların Okul Dışında Kalma Nedenleri ve Deneyimleri” başlıklı Doktora tezinin bir kısmından üretilmiştir.

** Öğr.Gör.Dr., Sinop Üniversitesi Eğitim Fakültesi, zenselman@gmail.com

*** Prof.Dr., Ankara Üniversitesi Eğitim Bilimleri Fakültesi, kkrktk@gmail.com
} 


\section{Giriş}

Eğitim, bireylerin yaşam koşullarını olumlu etkileyerek başta kültürel, sosyal ve ekonomik sermayelerinin artmasına, alt toplumsal sınıflar için ise yukarı yönde toplumsal hareketlilikte önemli bir role sahiptir. Eğitim, işgücü piyasası ediminden (performansından) sağlık, yaşam boyu öğrenmeye katılım, iş ve yaşam doyumu, suç, sosyal uyum, büyüme, vergi gelirleri ve sosyal yardım ödemelerine kadar değişen bireysel, sosyal ve mali sonuçları etkiler (Brunello ve De Paola, 2013). Eğitim, ekonomik boyutta toplumlar için büyüme, yeni bilgi ve teknolojilerin üretilmesi ile verimlilik ve rekabet gücünün artışına, sosyal destek alacak bireylerin azalmasına ve vergi gelirlerinin artışına; sosyal boyutta ise haklarının bilincinde olma yoluyla eşitsizliklerle savaşım, servet dağılımının iyileştirilmesi, kamusal kararlara etkin katılım, suç oranlarında azalma, sağlık koşullarının iyileşmesi, toplumsal uyum, barış ve çevrenin korunması gibi politik alanların gelişmesinde etkili bir araçtır (Hayes, Nelson, Tabin, Pearson ve Worthy, 2002; Rumberger, 1987). Eğitimin, siyasal ve demokratik toplum bilincini geliştirme, karmaşık sorunların anlaşılmasını sağlama, teknolojik ilerlemeye yardımcı olma ve kültürel yetenekleri keşfetme gibi çok yönlü etkilere sahip olduğu kabul edilmektedir. Eğitim, demokratikleşme, katılımcılık, insan hakları ve sosyal uyum gibi çağdaş toplumsal değerlerin yerleşmesinde ve politik istikrarın oluşturulmasında büyük önem taşımaktadır (European Commission, 2005; Helliwell, 2001; Organisation For Economic Co-Operation and Development (OECD), 2001; Tilak, 2002).

Eğitimin toplum ve bireyler için öneminin anlaşılmasından sonra eğitim, toplumlar için temel bir insan hakkı olarak kabul edilmiştir. Tarihsel süreç içinde eğitim hakkının uluslararası anlaşmalarda ve ulusal yasalarda "temel bir hak" olduğunu belirten maddelere yer verilmiştir. İnsan Hakları Evrensel Bildirgesinin 26. maddesinde ve Çocuk Haklarına Dair Sözleşmenin 28. maddesinde, "herkesin eğitim hakkına sahip olduğu, eğitimin ilk ve temel öğrenim düzeyinde zorunlu ve parasız olduğu belirtilmiştir (Birleşmiş Milletler, 1949; UNICEF, 2004). Anayasanın 42. Maddesi ile 222 sayılı İlköğretim ve Eğitim Kanununa göre "Kimse, eğitim ve öğrenim hakkından yoksun bırakılamaz. İlköğretim, kız ve erkek bütün vatandaşlar için zorunludur ve Devlet okullarında parasızdır (md. 2)” (Türkiye Büyük Millet Meclisi, 1982). Herkesin eğitim hakkına sahip olduğu 1961 Anayasasında ve sonraki tarihlerde eğitim ile ilgili çıkarılan tüm belgelerde yer almasına karşın, eğitim hakkının tüm bireyler tarafından kullanılması, uygulamada yaşama geçirilmemiş ve bugün bile güncelliğini koruyan bir sorun olarak kalmıştır. 
Eğitimle ilgili uluslararası ve ulusal yasal düzenlemelerde eğitimin temel bir hak olduğunun vurgulanması ve zorunlu eğitim süresinin uzatılmasına karşın okul dışında kalmalar, halen uluslararası düzeyde ve Türkiye'de eğitimle ilgili önemli sorunlardan biri olmaya devam etmektedir. UNESCO'nun eğitim alanında geliştirdiği 1990 yılında düzenlenen Herkes İçin Eğitim Konferansı'ndan bu yana dünya çapında eğitime erişimde önemli gelişmeler sağlanmakla birlikte eğitimde cinsiyet eşitliği ve cinsiyete dayalı adil bir toplum elde etmekten uzak kalmaktadır (UNESCO, 2015). Okulu erken birakma sadece Avrupa'da değil, gelişmiş dünyada da büyük bir sorun olarak görülmektedir. Avrupa Birliğinde (AB), 2007 yılında erkeklerin \%16.9'u ve kızların \%12.7'si okulu erken bırakmıştır (Dale, 2010) ve bunun görülme oranını 2020'ye kadar \%10'a düşürmek, AB eğitim stratejisinin temel ölçütlerinden biridir (European Commission, 2009). Ancak 2011 y1lında bu oran \%14.4 olarak gerçekleşmiştir. Bu düşüşün bir milyondan fazla kişinin okula devam etmesi ile eşdeğer olduğu belirtilmiştir (Vassiliou, 2011).

Resmi istatistik veriler incelendiğinde Türkiye'de çeşitli nedenlerle henüz eğitim hakkına erişemeyen önemli çağ nüfusunun olduğu görülmektedir. Türkiye'de ortaöğretim ve yükseköğretimde okullaşmanın düşüklüğü ve cinsiyetler arası eşitsizliklerin kadınlar aleyhine olduğu belirtilmektedir (Rankin ve Aytaç, 2006; Smits ve Hoşgör, 2006; Tansel, 2002; Tomul, 2007). TÜİK'in 2012 Çocuk İşgücü Anketi Sonuçlarına göre, 15-17 yaş grubundaki çocukların \%25.30’u okula devam etmemektedir. Türkiye'nin doğusunda ve kırsal bölgelerinde kadınların eğitime katılımının önemli bir eğitim sorunu olduğu vurgulanmaktadır (Smits ve Hoşgör, 2006). Kalkınma planlarında, ilk ve ortaöğretimde tüm çocukların okula erişiminin sağlanması, sınıf tekrarının ve okul terkinin azaltılması hedeflenmekle birlikte okullaşma oranlarında artışlar olmuş ancak plan hedefleri kısmen gerçekleşmiştir. Türkiye'de ilkokullarda net okullaşma oranı 2013 yılında \%98.86 iken 2014'te \%99.57'ye; ortaokullarda net okullaşma oranı \%93.09'dan \%94.52'ye; ortaöğretimdeki net okullaşma oranı ise \%70.06'dan \%76.65'e yükselmiştir (MEB, 2014).

Türkiye'de hâlâ temel eğitime ve sonradan zorunlu eğitime dâhil olan ortaöğretime hiç başlamayan veya başladıktan sonra erken ayrılan çocuklar bulunmaktadır. Okul dışında kalmak yalnızca eğitim hakkından mahrum olmayı değil aynı zamanda öteki insan haklardan yararlanmayı da etkilemektedir. Birçok araştırmada okul dışında kalmanın, yalnızca okul dışında kalanlara ilişsin ekonomik, psikolojik ve sosyal etkilerine değil aynı zamanda topluma olan maliyetlerine yer verilmiştir. Türkiye'de okul dışında kalma olgusu, çoğunlukla yalnız bir eğitim sorunu olarak kalmış ve eğitim sistemi, toplumdaki kurumsal 
güçlerin (hükümet, piyasa, popüler kültür, ana akım medya vs.) dışında, onlardan bağımsız bir ada olarak ele alınmıştır. Taylı (2008) okul dışında kalmanın; suç oranları, anti sosyal davranışları ve parasal kayıpları arttırdığı için, hem bireysel hem de toplumsal bir sorun olduğunu vurgulamıştır. Okul dışında kalma, eğitime yapılan yatırımların bireysel boyutta değerini kaybetmesine neden olurken; eğitime yönelik giderlerin boşa harcandığ 1 ve büyük bir ulusal kaynak kaybının söz konusu olduğu belirtilmektedir (Kavak ve Ekinci, 1994; Uysal, 2008).

Okul dışında kalmanın sosyoekonomik sonuçları ağır olduğu gibi bireysel sonuçları da oldukça ağırdır. Okul dışında kalan çocukların büyük bir bölümü bir insan hakları sorunu olan çocuk işçiliğiyle, emek sömürüsünün en vahşi biçimiyle yüz yüze kalmaktadır (United Nations International Children's Emergency Fund (UNICEF), 2014). Çocuklar ev içi hizmet üretimini (çocuk ve yaşlı bakımı, temizlik, yemek vb.) giderek daha fazla oranda üstlenmektedir (DİSK Araştırma Enstitüsü, 2013). TÜİ''in 2012 Çocuk İşgücü Anketi Sonuçlarına göre; 15-17 yaş grubunda çocukların \%15.60'1 çalışmakta, çalışan bu çocukların ise \%34.30’u bir okula devam etmektedir. Dünya genelinde kızların \%11.00'i, 15 yaşına gelmeden zorla evlendirilmekte ve bu da onların sağlık, eğitim ve korunma haklarını tehlikeye düşürmektedir (UNICEF, 2014). Türkiye genelinde, kız çocuklarının zorla gelin olma olasılığını azaltmada, kız çocuklarının eğitim düzeyleri en belirleyici etmendir. Kızların eğitim sürelerinin azalması, erken evlenme olasılığını arttırmaktadır. Türkiye’de, hiç okula kaydolmamış ya da ilkokuldan mezun olmamış kadınların erken evlendirilme olasılığı en az ortaöğretimden mezun kadınlardan 10.2 kat daha fazladır. Çocuğun zorla gelin olma olasılığı, ilkokulu bitirenler için 5.9 kat, ortaokulu bitirenler için ise 4.9 kattır (Yüksel-Kaptanoğlu ve Ergöçmen, 2012). Okul dışında kalanlar, okulu bir diploma alarak bitirenlere göre daha az kazanmaktadırlar. Öğretim düzeyleri arasındaki fark arttıkça kazançlar da düşmektedir. Benzer şekilde, okul dışında kalanların yılmış işçiler olarak işsiz kalma olasılıkları daha yüksektir ya da işgücünün dışındadırlar. Onlar, en yüksek eğitim düzeyi lise olanlardan yılda en az iki ay, lise üstü diploması olanlardan ise yılda yaklaşık üç ay daha az çalışırlar (Rouse, 2007). Bridgeland, Dilulio ve Morison'ın (2006) hazırladıkları rapora göre, liseyi terk edenler, mezun olanlara oranla yılda ortalama olarak 9.200 \$ daha az kazanırlarken, üniversiteyi bitirenler ile karşılaştırıldığında yaşam boyunca yaklaşık 1 milyon \$ daha az kazanırlar. Yine 2004 yılındaki işsizlik oranlarında, liseyi terk edenlerin işsizliği üniversite mezunlarına oranla üç katın üzerindedir. Onların bir yıldan diğer yıla yoksullaşması da liseden mezun olanlara göre iki katıdır. 
Eğitim sistemi açısından okulu terk oranları, eğitimin/okulun nitelik göstergeleri arasında yer almaktadır; düşük terk oranları eğitim sisteminin niteliğini olumlarken, yüksek terk oranları eğitimin niteliğine ilişkin olumsuzluk olarak değerlendirilmektedir. Eğitimde verimliliğin nicelik boyutunda, özellikle eğitimin/okulun iç verimliliğinin hesaplanmasında kullanılan kayıp oranı, okulu terk edenlerden ve sınıf tekrarlarından oluşmaktadır. Kayıp (terk) oranı yükseldikçe eğitimin/okulun iç verimliliği düşmektedir.

Okuldan erken ayrılma, zayıf okul deneyimi, yetenek eksikliği, eğitime işgücü piyasasından algılanan getirilerin düşük olması, gelecekteki yardımlarda büyük oranda indirim yapılması, zayıf sosyal çevre ve akran etkisi gibi birçok etkenin sonucudur (Brunello ve De Paola, 2013). Sonuç olarak okul dışında kalan çocuklar bireysel açıdan birçok olumsuzlukla karşılaşabilmektedir. Bunların bazıları: çocukların bilişsel, sosyal, psikolojik ve bedensel gelişimi olumsuz yönde etkilenmekte ve böylece çocukların sağlıklı gelişme, toplumsallaşma ve eğitilme dolayısıyla yaşam hakları ihmal ve ihlal edilme ile yüz yüze kalmaktadırlar. Gelecekte işsiz kalma, daha düşük gelir elde etme, sosyal haklardan haberdar olmama, sosyal haklardan daha az yararlanma sorunlarıyla yüz yüze gelme olasılığ yüksektir.

Çalışma sonuçları incelendiğinde gerek "eğitime katılımı" gerekse "okul terkini”" etkileyen kaynakların benzerlik gösterdiği belirlenmiştir. Genel olarak okul terki bireysel, aile, toplum ve ülke düzeyinde kültürel, yapısal ve kaynak boyutları ile ilgili olduğu söylenebilir. Rosenthal (1998), okul terki ile ilgili yapılmış 37 çalışmanın bulgularını değerlendirerek, okul terki ile ilişkili okul dışı değişkenleri 12 kümede -125 özel değişkentoplamıştır. Bunlar: Sosyoekonomik durum, azınlık grup durumu, cinsiyet, toplum özellikleri, hanehalkı stresi, yetişkin rolleri alma, okulda kalmak için sosyal destek, aile süreçleri, eğitimde öğrenci katılımı, sosyal uyuma karşı özerklik gereksinimi, sosyal sapkınlık ve kişilik özellikleri. Yapılan çalışmalarda eğitime erişimde eşitsizliklerin; makro düzeyde ülkenin sosyoekonomik yapısı ve öncelikleri, mikro düzeyde ise ailesel ve bireysel etmenlerden kaynaklandığı belirtilmektedir (Tomul, 2007). Berktold, Geis ve Kaufman (1998), sekizinci sınıf öğrencilerinin okul terki nedeniyle yaptıkları boylamsal çalışmada okul terklerin \%77 oranında okulla, \%34'ünün aile ile ilgili, \%32'sinin çalışma ile ilgili olduğunu belirtmişlerdir. Gümüş’ün (2014) bulgularına göre, yetişkin eğitimi düzeyi ve kadınların toplumdaki güçlenmesi gibi sosyal bağlam etkenlerinin, ebeveyn eğitimi, hanehalkı zenginliği, hanehalkı büyüklüğü gibi tanınmış hane düzeyindeki etkenlerin çocukların okul katılımı açısından çok önemlidir. 
Okul terkindeki değişimin çoğu (\%72) hanehalkı düzeyindeki faktörlerden kaynaklanmaktadır. Sosyoekonomik kaynaklar (ebeveyn eğitimi, babanın mesleği ve serveti) en önemlisidir. Ailenin sosyal, kültürel ve ekonomik yapısı okul terk ya da okula devamda önemli bir rol oynamaktadır (Huisman ve Smits, 2015). Ailenin yaşadığı yer (kır, kent), ebeveynlerin eğitimi, ebeveynlerin mesleği, hanehalkı büyüklüğü, doğum sırası ve aile geliri gibi ailesel etmenler çocukların eğitim süresinde etkilidir. Özellikle ebeveynlerin eğitim düzeyi ile kişi başı gelirin çocuğun eğitim süresi üzerinde mühim etmenler olduğu ve diğer sosyoekonomik etmenlerle yüksek seviyede ilişkili olduğu vurgulanmaktadır (Blanden ve Gregg, 2004; Crosnoe, Mistry ve Elder Jr, 2002; Machin ve Vignoles, 2004; Smits ve Hoşgör, 2006; Tomul, 2007). Yetişkin eğitimi düzeyi ve kadınların toplumdaki güçlenmesi gibi sosyal bağlam faktörlerinin, ebeveyn eğitimi, hanehalkı zenginliği, ev büyüklüğü gibi tanınmış hane düzeyindeki faktörlerin çocukların okul katılımı açısından çok önemlidir (Gümüş, 2014). Literatürde bireye ait cinsiyet, ırk ve etnik köken, göçmenlik durumu ve eğitim dilinden farklı anadili konuşma gibi demografik değişkenlerin okul terk ile önemli düzeyde ilişkili olduğu belirtilmektedir (Rumberger, 2001).

Türkiye'de okul dışında kalma konusunda yapılan çalışmaların bir kısmı, okulu terk etme riski taşıyan öğrencileri önceden saptamayı ve önlem almayı amaçlamışlardır. (MEB, 2013) yaptıkları çalışmaya göre okul terkinin nedenleri; aileye bağlı nedenler (ailenin sosyoekonomik yapısı, aile baskısı/ilgisizliği), okula karşı duyulan güvenin azalması, arkadaşların ve sosyal çevrenin etkisi, okul başarısızlığı (akademik başarısızlık, sınıf tekrarı, devamsızlık) ve erken evlilikler olarak açıklanmıştır. Tomul (2007), çalışmasında gelir düzeyi yüksek olan ailelerdeki çocukların eğitime katılımının da yüksek olduğu; her iki cinsiyetin eğitime katılımlarının bölge ve gelire göre farklılık gösterdiği; bütün gelir düzeylerinde ve bölgelerde kadınların eğitime katılım oranlarının erkeklerinkinden düşük olduğu; gelirdeki yükselişin eğitime katılıma etkisinin cinsiyete ve bölgelere göre farklılık gösterdiği ortaya çıkmıştır.

Özer, Gençtanırım ve Ergene (2011), disiplin cezası alma, alkol-sigara kullanımı ve antisosyal davranışların okulu terk etme riskini artırdığını, sosyal desteğin, özellikle öğretmen desteğinin okulu terk etme riskini azalttığını belirtmektedirler. Taş, Selvitopu, Bora ve Demirkaya (2013) akranların tutum ve davranışlarının terk riskini etkilediğini; Şimşek (2011) ise, okul dışında kalma olasılığının kişisel özelliklere ek olarak, aile yapısı (çok çocuklu aile), eğitim sistemi, okuldan ve öğretmenden memnuniyet gibi etmenlerin okulu terk olasılığını etkilediğini belirtmektedirler. 
Okul dışında kalma bağlamında özellikle kız çocuklarının okullaşma engelleri üzerinde duran çalışmalar da yürütülmüştür. Bora (2012), ailenin ekonomik durumu, kız çocuklarına biçilmiş toplumsal roller, okullardaki karma eğitim ve giysi uygulamalarının velilerin kız çocuklarını ortaöğretime göndermemelerinde etkili olduğunu belirtmektedir. Adıgüzel (2013), özellikle kızların okul dışında kalmalarının temel nedeninin sosyoekonomik ve kültürel etmenler olduğunu belirtmiştir. Şirin, Özdemir ve Sezgin'in (2009) çalışma sonuçlarına göre; erkekler aile gelirine katkı sunmak, kızlar ise çalışan anneye destek vermek için evdeki kardeşlerin bakımını üstlenme nedenleriyle okul dışında kalmaktadırlar.

Huisman ve Smits'e (2015) göre okul terkte önemli etkenlerden birinin de eğitim kaynakları (okulların ve öğretmenlerin mevcudiyeti) ile ilgilidir. Taylı (2008) öğrencilerin; öğretmenlerle ve arkadaşlarıyla olan ilişkilerinin, okula ve aileye ilişkin nedenlerin, kişisel ve toplumsal nedenlerin okulu bırakmasında önemli rol oynadığını vurgulamaktadır. Uysal (2008), okulu bırakmayı etkileyen çevresel etmenlerin en önemlisinin okul çevresi olduğunu belirtmiştir. Okuldaki aksaklıklar, özellikle okulun niteliği, büyüklüğü, atmosferi ve öğretmenlerin tutumları çocukların eğitim sistemi içinde kalmalarını etkilemektedir. Berktold ve diğerlerinin (1998) yaptıkları boylamsal çalışmada okul terkinde okulla ilgili en belirgin nedenler ise "okulu sevmeme" (\%46.00), "okul başarısızlığı" (\%39.00), "öğretmenlerle iyi ilişkilerin kötü olması" (\%29.00) ve "iş bulup çalışma" (\%27.00) olduğu belirtilmiştir.

Andrei, Teodorescu ve Oancea (2012), 2000-2009 yılları süresince 27 AB ülkesinde kaydedilen veri setlerini kullanarak, okul terkiyle ilişkili olarak yaptıkları çalışmada GSYİH içindeki eğitim harcamalarının payının artmasının eğitimin niteliğinin artmasına ve dolayısıyla okul terk oranlarının azalmasına neden olduğunu; öğretmen başına düşen öğrenci sayısı azaldıkça okul terkinin önemli ölçüde azaldığını; işgücü piyasasındaki işsizlik oranı yükseldikçe okul terk oranlarının da yükseldiğini vurgulamaktadırlar. Ayrıca AB ülkelerindeki okul terkinin belirli bir düzeyini kültürel etmenlerin, kıtaya yapılan göçlerin, ekonomik ve sosyal etmenlerin belirlediği de belirtilmektedir.

Huisman ve Smits (2015), yaptıkları çalışmada okul terkinde bölgenin gelişim düzeyinin de önemli rol oynadığını belirtmektedirler. Kamusal olanakların yerleşim yerlerine eşit oranda dağılmaması, hem ülke coğrafyasında şehirlerin konumuna hem de şehir coğrafyasında konutun bulunduğu yere bağlı olarak eğitim-öğretim hizmetlerinin niteliğinin farklılaşmasına neden olmaktadır (Eskicumalı ve Önce, 2014). Okul dışında 
kalma olgusunda, çocukların yaşadığı yerin (mekânın) nitelikleri yeterince dikkate alınmamıştır. Kent nüfusunun, toplumsal konumlarına (etnik, sınıfsal kökenleri, kültürel ve dinsel aidiyetleri vb.) bağlı olarak belirli kentsel mekânlarda yoğunlaşmaları ve birbirlerinden fiziksel olarak kopmaları ve sınırlı bir kültürel etkileşim içinde bulunmaları, eğitim kurumlarını da sosyo-mekansal bir bölünmeye uğratmaktadır (Ünal, Özsoy, Yıldız, Güngör, Çankaya ve Aylar, 2010). Çelik (2014) ise aynı sınırlılı̆̆ı olan (dezavantajlı) mahallelerde yaşıyor olsalar da okula devam eden öğrencilerin sosyoekonomik ve etnik açıdan okul terklerinden ayrıştıklarını belirtmektedir.

Türkiye, 2010 yılından itibaren UNICEF ile UNESCO İstatistik Enstitüsü’nün yürüttüğü Okul Dışındaki Çocuklar Küresel Girişiminin katılımcısı 25 ülke arasında olmasına karşın, Milli Eğitim Bakanlığı (MEB), 2013 yılına kadar okul dışında kalan çocuklara ilişkin kapsamlı bir araştırma yapmamıştır. MEB, 2013 yılındaki çalışmayı da UNICEF işbirliğiyle yapmıştır (MEB, 2013). Bu yüzden sorun güncelliğini korumaktadır. Özellikle okul dışında kalmanın nedenlerinden olan sosyoekonomik etmenler, birçok araştırmada vurgulanmasına karşın çoğunlukla bu çalışmalarda sosyoekonomik eşitsizliklerin nedenleri ve eğitim sisteminin eşitsizlik yaratan uygulamaları sorun edilmemiş ve bu eşitsizliklerin doğallığ benimsenmiştir.

Tomul'a (2007) göre, eğitim, toplumsal ve iktisadi eşitsizlikleri hafifletme olasılığı içermenin yanında, amaç, yapı ve süreçlerindeki yanlışlıklarla mevcut eşitsizlikleri arttırarak yeniden üretme olasılığını da barındırmaktadır. Eğitime erişimi yansıtan okullaşma oranları, eğitimdeki eşitsizlikleri daha da görünür k1lmaktadır. Türkiye'de hedeflenen düzeyde katılımın sağlanmadığı eğitim kademelerinden biri de ortaöğretimdir. Ortaöğretimde hedeflenen okullaşma oranlarının sağlanamadığı gibi buradaki okul çeşitliliği ve eğitim niteliği de önemli politik tartışmaların merkezinde yer almaktadır. Eğitime erişimde, ortaöğretim, eğitim sistemi içinde önemli bir kademedir. Köse’ye (2006) göre ilköğretimden sonraki aşamada öğrencilerin hangi tür bir ortaöğretime devam edeceği kararı, öğrencilerin sonraki yaşam koşullarını belirlemede önemlidir. Huisman ve Smits, J. (2015), gelişmekte olan ülkelerde ilkokuldan ortaöğretime geçişin, çocukların eğitim kariyerlerinde önemli bir kırılma noktası olduğunu vurgulamaktadır. Öğrenim gören öğrencilerden okulu terk etmeyi düşünenler, bu kararlarını ağırlıkla lise yıllarında uygulamaktadırlar (Battin-Pearson, Newcomb, Abbott, Hill, Catalano ve Hawkins, 2000).

Ulusal ve uluslararası alanyazın incelendiğinde öğrencilerinin okul dışında kalmalarını etkileyen etkenlerin çoklu bağlantılı analizlerle bir bütün olarak belirlenmesinin 
sonuçları iyileştirmeye yönelik müdahale edilebilecek değişkenlerin belirlenmesine, oluşturulacak politika ve uygulamalara veri sağlama açısından önemli olacağı düşünülmektedir. Uluslararası ve ulusal düzeyde eğitime katılım veya okulu terk nedenleri ile ilgili yapılan çalışmalarda; eğitim kademesi, ülkelerde uygulanan sosyal politikalara, ülkelerin gelişmişlik durumuna ve zamana bağlı olarak değişebileceğini ortaya koymuştur. Türkiye'de ortaöğretim düzeyinde okul terklerini etkileyen sosyal-ekonomik nedenlerin belirlenmesinin gelecekte eğitime erişimi artırmak için oluşturulacak makro/mikro politikalara katkı sağlayabileceği düşünülmektedir. Bu nedenle Türkiye'de ortaöğretim çağ nüfusunun okul dışında kalmasını etkileyen bireysel ve sosyoekonomik değişkenlerin belirlenmesinin önemli olacağı düşünülmektedir.

$\mathrm{Bu}$ çalışma Türkiye'de ortaöğretim çağ nüfusunun cinsiyete göre okul dışında kalmasını etkileyen bireysel ve sosyoekonomik değişkenlerin etkisinin tarihsel süreçteki değişimini belirlemeyi amaçlanmaktadır.

\section{Yöntem}

Çalışma seçilmiş yıllara göre Türkiye'de ortaöğretim çağ nüfusunun okul dışında kalmasını etkileyen bireysel ve sosyoekonomik değişkenlerin belirlenmesini amaçladığından araştırma ilişkisel tarama modelindedir.

\section{Veri Kaynakları}

Araştırmanın istatistiksel verileri DİE 2003 Hanehalkı Bütçe Anketi ile TÜİK'in 2011 ve 2016 yıllarında yaptığg Hanehalkı Bütçe Anketlerindeki Fert ve Hane mikro veri setlerinden elde edilmiştir. Hanehalkı bütçe anketleri, hanelerin sosyoekonomik yapıları, yaşam düzeyleri, harcama kalıplarına ilişkin bilgi içeren ve halkın gereksinimlerinin belirlenmesi, kullanılabilir gelirin haneler ya da bireyler arasında nasıl dağıldığının bilinmesi ve uygulanan sosyoekonomik politikaların geçerliğinin test edilmesi amacıyla kullanılan en önemli kaynaklardan biridir (TÜİK, 2009) Bu nedenle araştırmada kullanılan veriler ikincil veri özelliği taşımaktadır (Smith, 2017). Yukarıda belirtilen anketlerdeki verilerden araştırma amaçlarına uygun verileri elde etmek için TÜİK'ten veri isteminde bulunulmuştur. TÜİK, veri istemine olumlu yanıt vermiş, 2003-2013 yıllarına ait ilgili anketleri CD biçiminde postayla, 2016 yılına ait anket verilerini elektronik ortamda erişilebilir olarak araştırmacıya ulaştırmıştır (Ek-1).

2003 Hanehalkı Bütçe Anketi (DİE, 2003) 2002 yılında gelir dağılımı bilgilerini de elde etmeye yönelik olarak hazırlanmıştır. 2003 yılının 12 ayı süresince toplam 25920 
haneden (kentte 1512, kırsalda 648 hane) 107614 kişiye uygulanmıştır. Türkiye geneli, kentsel ve kırsal yerler ayrımında toplumsal ve ekonomik veriler elde edilmiştir. Hanehalklarından bilgiler; görüşme, kayıt ve gözlem yöntemleriyle derlenmiştir.

2011 Hanehalkı Bütçe Anketinin (TÜİK, 2011) kapsamı, Türkiye Cumhuriyeti sınırları içinde bulunan hanelerde yaşayan fertlerdir. Araştırmada kurumsal nüfus kapsamında bulunanlar ile göçer nüfus kapsam dışı tutulmuştur. Anketin örnekleme yapısı; "Türkiye, Kent, Kır" temelinde tahmin verme amacına uygun olarak oluşturulmuştur. 1 Ocak-31 Aralık 2011 tarihleri arasında bir y1l süre ile her ay değişen 1104, yıllık toplam 13248 örnek hanehalkına uygulanmıştır. Anketle Türkiye geneli, kentsel ve kırsal yerler ayrımında sosyal ve ekonomik veriler elde edilmiştir. Hanehalklarından bilgiler; görüşme, kayıt ve gözlem yöntemleriyle derlenmiştir.

2016 Hanehalkı Bütçe Anketinin (TÜİK, 2016) kapsamı, Türkiye Cumhuriyeti sınırları içinde bulunan tüm yerleşim yerlerindeki hanelerde yaşayan fertlerdir. Anket, 1 Ocak-31 Aralık 2016 tarihleri arasında bir yıl süre ile her ay değişen aylık toplam 1296 örnek hanehalkı olmak üzere yıl boyunca toplam 15552 hanehalkına uygulanmıştır. Ancak 12096 hanehalkından toplanan veriler amaca uygun yeterliktedir. 2016 Hanehalkı Bütçe Anketi, her ay ortalama 1296 farklı örnek hanenin dönüşümlü olarak izlenmesi yoluyla yürütülmüştür. Yıl boyunca toplam 15552 hanehalkına anket uygulanmış, anketi geçerli olan hanehalkı sayısı 12096 olmuştur. Hanehalklarından bilgiler; görüşme, kayıt ve gözlem yöntemleriyle derlenmiştir.

Örneklem olarak DİE tarafindan uygulanan 2003 yılı ile TÜİK tarafindan uygulanan 2011 ve 2016 yılı Hanehalkı İşgücü Anketlerindeki mikro verilerden seçilen 13-17 yaş grubundaki çocuklardır. Veri setlerinin yılları belirlenirken 2008 ekonomik krizi öncesi ve sonrasını karşılaştırıp okul dışında kalmayı etkileyen faktörlerin değişim eğilimini görmek amaçlanmıştır. $\mathrm{Bu}$ amaçla en güncel veriler için $2016 \mathrm{y}$ 1lı, kriz sonrasının etkilerini saptamak için 2011 yılı, kriz öncesi durumu ortaya çıkarmak için şimdiye kadar içerdiği değişkenler ve örneklem büyüklüğü bakımından en kapsamlı araştırma olduğu için 2003 yılı verileri seçilmiştir. Çalışmanın evrenini 2003, 2011 ve 2016 yılları Türkiye'de 13-17 yaş grubundaki ortaöğretim çağındaki çocuklar oluşturmaktadır. 2003 ve 2011 Hanehalkı Bütçe Anketi Fert Veri Setinde yaş değişkeni bitirilmiş yaş olarak belirtildiği için 13-17 yaş grubu, 2016 veri setinde ise yaş içinde bulunulan yaşı belirttiği için 14-18 yaş grubu alınmıştır. Bu açıdan bu çalışmadaki ortaöğretim çağı nüfus kavramı, içinde bulunulan 14-18 yaş nüfusunu kapsamaktadır. 


\section{İşlem}

$\mathrm{Bu}$ araştırmanın bağımlı değişkeni, öğrenci/öğrenci değil, bağımsız değişkenleri ise; 13-17 yaş nüfusun yaşadığı Yerleşim Birimi (kır-kent), Sağlık Güvencesi, Engellilik Durumu (var/yok), Baba Eğitim Düzeyi, Anne Eğitim Düzeyi, Kişibaşı Yıllık Gelir ve Hanehalkı Büyüklüğüdür. Bağımlı değişken herhangi bir eğitim kurumuna kayıtlı olup olmadığı verisinden alınmıştır. 2003 ve 2011 Hanehalkı Bütçe Anketi Fert Veri Setine 13-17 yaş aralığındaki nüfusun öğrenci olup olmama durumu dikkate alınarak veriler düzenlenmiştir. Yaş ile ilgili değerler bitirilmiş yaşı belirtmektedir. Yani 13 yaş grubu 13 yaşını bitirip 14 yaşından gün alanları belirtmektedir. 2016 Hanehalkı Bütçe Anketi Fert Veri Setinde 14-18 yaş aralığındaki nüfusun öğrencilik statüsü (öğrenci (1) / öğrenci değil (0) gözetilerek veriler düzenlenmiştir. 2016 yılı yaş verilerinde, içinde bulunduğu yaş esas alınmıştır. Öğrenci olmayanlar herhangi bir eğitim kademesinde kayıtlı olmayanları belirtmektedir. Bu araştırmada okul dışında kalmayı yordayan değişkenleri belirlemek amaçlandığından Binary lojistik regresyon çözümlemesinde "öğrenci” 0”, öğrenci değil ise "1" olarak kodlanmıştır.

13-17 yaş nüfus, anne ve baba 2003, 2011 ve 2016 Hanehalkı Bütçe Anketi fert veri setinde Hanehalkı Reisine Yakınlığı maddesine göre belirlenmiştir. 2003 ve 2011 veri setinde bu madde kodlamasında Hanehalkı Reisi “0”, Eşi “1” ve Oğlu/Kızı "2” şeklinde kodlanmıştır. Ferdin cinsiyeti kısmındaki Erkek “1”, Kız "2” olarak kodlanmıştır. Hanehalkı reisi değişkeninde " 0 ” kodlu olup cinsiyeti erkek olarak belirtilenler "baba”, Hanehalkı reisi değişkeninde "1" kodlu olup cinsiyeti kadın olarak belirtilenler "anne", Hanehalkı reisi değişkeninde “2” kodlu olup 13-17 yaş aralığında olanlar ise oğlu/kızı kabul edilmiştir.

TÜIK 2016 veri setinde bu madde Hanehalkı Sorumlusu “1”, Eşi “2” ve Oğlu/Kızı “3” şeklinde; Ferdin cinsiyeti Erkek “1”, Kadın “2” olarak kodlanmıştır. Hanehalk1 sorumlusu değişkeninde "1" kodlu olup cinsiyeti erkek olarak belirtilenler "baba", hanehalk1 sorumlusu değişkeninde " 2 " kodlu olup cinsiyeti kadın olarak belirtilenler "anne", hanehalk1 sorumlusu değişkeninde "2" kodlu olup 13-17 yaş aralığında olanlar ise oğlu/kızı kabul edilmiştir. Veri setinde "Bülten” kodları aynı olanlar aynı aile bileşimini belirtmektedirler.

Bağımsız değişken olarak 13-17 yaş nüfusun Cinsiyet (erkek/kız), yaşadığı Yerleşim Birimi (kır-kent), Sağlık Güvencesi, Engellilik Durumu (var/yok), Baba Eğitim Düzeyi, Anne Eğitim Düzeyi, Kişibaşı Yıllık Gelir ve Hanehalkı Büyüklüğü değişkenleri alınmıştır.

Cinsiyet erkek (1) ve kız (2) şeklinde kodlanmış, Binary Lojistik Regresyon çözümlemesinde erkek referans değer olarak alınmıştır. 
Yaşadığı Yerleşim birimi Kır-kent ayrımına göre alınmıştır. TÜİK (2003, 2011) nüfusu 20000 ve daha az olan yerleşim yerlerini "Kır" (1) 20001 ve daha fazla olan yerleşim yerlerini ise "Kent" (2), olarak tanımlamıştır. Binary Lojistik Regresyon çözümlemesinde kent referans değer olarak alınmıştır. 2016 Hanehalkı Bütçe Anketi Fert ve Hane Veri Setinde kır/ kent ayrımı yer almamaktadır.

Sağlık güvencesi değişkeni; Sağlık Sigortasının olup olmadığı verisine göre yapılmıştır. Bu değişken “Zorunlu ve İsteğe Bağlı Sigortalı”, "Yeşil Kartlı”, "Herhangi Bir Güvencesi Yok” şeklinde sınıflandırılmıştır. Zorunlu ve İsteğe Bağlı Sigortalı “1”, Yeşil Kart "2" ve Herhangi Bir Güvencesi Yok “3” olarak kodlanmıştır. Binary Lojistik Regresyon çözümlemesinde “Zorunlu ve İsteğe Bağlı Sigortalı" referans değer olarak alınmıştır.

Engellilik durumu (Var/Yok) değişkeni; bu bağımsız değişken 2011 ve 2016 Hanehalkı Bütçe Anketi Fert Veri Setinde "Günlük etkinliğe engel fiziksel ya da bilişsel sorun olup olmadığı” şeklinde yer almaktadır. 2003 Hanehalkı Bütçe Anketi Fert Veri Setine bu değişken ile ilgili herhangi bir madde bulunmamaktadır. Engelinin olması “1”, engelinin olmaması ise "2" olarak kodlanmıştır. Binary Lojistik Regresyon çözümlemesinde “engelinin olmaması" referans değer olarak alınmıştır.

Baba ve anne eğitim düzeyi 2003, 2011 ve 2016 Hanehalkı Bütçe Anketi Fert Veri Setine dayalı olarak Tablo 2'de verildiği gibi yeniden sınıflandırılmış ve kodlanmıştır. Binary Lojistik Regresyon çözümlemesinde "Yükseköğretim mezunu” referans değer olarak alınmıştır.

Anne ve baba eğitim düzeyi değişkeninin 2003, 2011 ve 2016 Hanehalkı Bütçe Anketi Fert Veri Seti'ne dayalı olarak yeniden sınıflandırılıp kodlanmasına ilişkin dönüşümler Tablo 1'de verilmiştir.

Tablo 1 incelendiğinde Hanehalkı Bütçe Anketi hane veri setindeki kod ve tanımları üzerinde birleştirmeler ve yeniden adlandırmalar yapılmıştır. Örneğin veri setindeki “okuryazar değil”" ile "okur-yazar olup bir okul bitirmedi”ye ait olan 1. ve 2. kodlar araştırma veri setinde "1. mezun değil”" olarak birleştirilmiştir.

Hanenin büyüklüğü olarak; hanede yaşayan toplam fert sayısı alınmıştır. Hanenin büyüklüğü 2003, 2011 ve 2016 Hanehalkı Bütçe Anketi Hane Veri Setinde ham veriler gruplanarak yeniden kodlanmıştır. Buna göre hane büyüklüğü 3 ve daha az ise "1", dört kişi “2”, beş kişi “" 3 ”, altı kişi “4”, yedi ve sekiz kişi " 5 ” ve dokuz kişi ve fazlası ise " 6 " olarak 
kodlanmıştır. Binary Lojistik Regresyon çözümlemesinde hane büyüklüğü "3 ve daha az" olan referans değer olarak alınmıştır.

Tablo 1. Baba ve Anne Eğitim Düzeyinin Yeniden Oluşturulan Kategori ve Kodları 2003, 2011, 2016 Hanehalk1 Bütçe Anketi Araştırma Veri Setindeki Kategori ve Hane Veri Setinde Kod ve Tanımı Kodları

1. Okur-yazar değil

2. Okur-yazar olup bir okul bitirmedi

3. İlkokul

4. İlköğretim

5. Ortaokul

6. Orta dengi meslek
1. Mezun Değil (1. Okur-yazar değil+2.

Okur-yazar olup bir okul bitirmedi

\begin{tabular}{ll}
\hline $\begin{array}{l}\text { 7. Lise } \\
\text { 8. Lise dengi meslek }\end{array}$ & $\begin{array}{l}\text { 4. Lise ve dengi okul mezunu (7. Lise+8. } \\
\text { Lise dengi meslek) }\end{array}$ \\
\hline 9.2 yıllık yüksekokul & $\begin{array}{l}\text { 5. Yükseköğretim mezunu }(9.2 \text { yıllık } \\
\text { 10. } 4 \text { yıllık yüksekokul, fakülte }\end{array}$ \\
$\begin{array}{l}\text { 11. Yükssekokul+4 yıllık yüksekokul, fakülte+ } \\
\text { Yüksek lisans, doktora })\end{array}$
\end{tabular}

Gelir değişkeni 2003, 2011 ve 2016 Hanehalkı Bütçe Anketi Hane Veri Setinde "Yıllık Kullanılabilir Hanehalkı Geliri” verisi temel alınarak belirlenmiştir. İlk aşamada Yıllık Kullanılabilir Hanehalkı Geliri Hanehalkı Büyüklüğü değerine bölünerek kişi başı gelir hesaplanmıştır. İkinci aşamada kişi başı gelir büyükten küçüğe doğru sıralanarak nüfusun \%20'lik dilimlerine denk gelen değerler belirlenmiş ve isimlendirilmiştir. Kişi başına kullanılabilir yıllık gelir aralığı ve grup tanımları \%20’lik nüfus dilimlerine göre Tablo 2'de verilmiştir.

Tablo 2. Yüzde Yirmilik Nüfus Dilimlerine Göre Kişi Başına Kullanılabilir Yıllık Gelir Aralığ ve Grup Tanımları

\begin{tabular}{lllll}
\hline Nüfus & Grup & Yıllara Göre Kişi Başına Düşen Gelir Aralığı & \\
Grupları & Tanımı & $\mathbf{2 0 0 3}$ Yılı (TL) & 2011 Yılı (YTL) & 2016 Yılı (YTL) \\
\hline I.\%20 & Alt Gelir & 750984285,7 ve altı & 2122,27 ve altı & 3759 ve altı \\
II.\%20 & Ortaaltı & $750984286-1189774000$ & $2122,28-3449,75$ & $3760-5909$ arası \\
& Gelir & arası & aras1 & \\
III.\%20 & Orta Gelir & $1189774001-1729105363$ & $3449,76-5157,5$ & $5910-8376$ arası
\end{tabular}




\begin{tabular}{|c|c|c|c|c|}
\hline \multirow{2}{*}{$\begin{array}{l}\text { Nüfus } \\
\text { Grupları }\end{array}$} & \multirow{2}{*}{$\begin{array}{l}\text { Grup } \\
\text { Tanımı }\end{array}$} & \multicolumn{2}{|c|}{ Yıllara Göre Kişi Başına Düşen Gelir Aralığı } & \multirow[b]{2}{*}{2016 Yll (YTL) } \\
\hline & & 2003 Yılı (TL) & 2011 Yılı (YTL) & \\
\hline \multirow{3}{*}{ IV.\%20 } & & aras1 & aras1 & \\
\hline & Ortaüstü & $1729105364-$ & $5157,51-7683,36$ & $8377-12438$ aras 1 \\
\hline & Gelir & 2647500000 aras 1 & aras1 & \\
\hline VI.\%20 & Üst Gelir & 2647500001 ve yukarıs1 & 7683,37 ve yukarısı & 12439 ve yukarısı \\
\hline
\end{tabular}

Tablo 2'de görüldüğü gibi, veri setinde Alt Gelir Grubu “1”, Ortaaltı Gelir Grubu “2”, Orta Gelir Grubu “3”, Ortaüstü Gelir Grubu "4" ve Üst Gelir Grubu "5” olarak kodlanmıştır. Binary Lojistik Regresyon çözümlemesinde "Üst Gelir Grubu” referans değer olarak alınmıştır.

\section{Verilerin Analizi}

Okul dışında kalma olasılığını etkileyen değişkenler ve bunların etkilerini belirlemek için Lojistik Regresyon çözümlemesi kullanılmıştır. Lojistik Regresyonda amaç, iki veya daha fazla kategoriden oluşan bir bağımlı değişkendeki değerleri yordamaktır. Bağımsız değişkenler kategorik ve/veya sayısal olabilir. Bağımlı değişken yalnızca iki kategoriden oluştuğundan, lojistik regresyon, bağımsız değişkenlerin değerleri değiştikçe bağımlı değişkenin oluşma olasılığını yordamaktadır (Mertler ve Reinhart, 2017, s. 18). Yordanan bağımlı değişkenin dağılımı hakkında herhangi bir varsayımın (yordayıcı bağımsız değişkenlerin normal dağılması, doğrusallık ve varyans-kovaryans matrislerinin eşitliği gibi) gerekmemesinin yanı sıra yordayıcıların sürekli, kesintili veya ikili karışımı olabilmeleri nedeniyle lojistik regresyon tercih edilmektedir (Tabachnick ve Fidell, 2015, s. 439).

Lojistik regresyon, her ne kadar iki veya daha fazla kategoriden oluşan bir bağımlı değişkendeki değerleri yordamak için kullanılabilse de bu araştırmada bağımlı değişken ikili ve kesikli olduğu için Binary Lojistik Regresyon kullanılmıştır. Binary Lojistik Regresyon katsayısı $(\operatorname{Exp}(B))$ yordayıcı değişkenlerin bağımlı değişken üzerindeki etki durumunu ve düzeyini çözümleme olanağı sunmaktadır (Özdamar, 2004). Bağımsız değişkenler (cinsiyet, kişi başına kullanılabilir yıllık gelir, yerleşim birimi, hanehalkı büyüklüğü, annenin ve babanın eğitim düzeyi, sağlık güvencesi, engel durumu) ise kategorik özelliktedir. Bu özellikleri nedeniyle yordayıcı değişkenlerin yordanan değişken üzerindeki etki durumunu çözümlemek için Binary Lojistik Regresyon uygulanmıştır. 
Lojistik regresyonun tercih edilmesiyle ilişkili bazı önemli zorunluklar vardır. Örneğin yordayıcı değişkenlerin kategorilerinde yer alan birey sayısı ve oranı çok az ise çözümleme yeterince geniş parametre tahminleri ile standart hata üretebilmekte ve modelin güvenilirliği azalmaktadır. Araştırmada her yordayıcı değişkende en aşağı 50 birimlik kategorilerin olması dikkate alınmış (Moineddin, Matheson ve Glazier, 2007), bu amaca ulaşılmadığında, kategori birleştirme işlemi yerine ilgili değişkenin analizden çıkarılması yeğlenmiştir. Lojistik regresyona giren bağımsız değişkenler arasındaki yüksek korelasyon, çoklu bağlantı sorununu ortaya çıkarmaktadır. Bu durumda da bazı değişkenlerin analizden çıkarılması gerekmektedir. Yine gözlemlenen veriler ile modelin öngördüğü değerler arasındaki standardize edilmiş artıklara veya hatalara sahip (Zresid değeri 2.5 'ten büyük) uç değerler analizden çıkarılmıştır.

Model sekiz bağımsız değişken içermektedir (cinsiyet, kişi başına kullanılabilir yıllık gelir, yerleşim birimi, hanehalkı büyüklüğü, annenin ve babanın eğitim düzeyi, sağlık güvencesi ve engel durumu). Araştırmada Lojistik Regresyon iki aşamalı modelle uygulanmıştır. İlk önce bağımsız değişkenlerin bağımlı değişken üzerindeki etkisinin anlamlılık durumunu belirlemek için model belirlenmiştir. Bağımsız değişkenlerin yordamada etkisi $\mathrm{p}<0.05$ anlamlılık düzeyine bakılarak değerlendirilmiştir. Modelin ikinci aşamasında, yordayıcı değişkenlerin alt kategorilerinin yordanan değişken üzerindeki göreli etkisini ifade eden katsayılar $(\operatorname{Exp}(B))$ belirlenmiştir.

Araştırmanın amaçları doğrultusunda sosyoekonomik değişkenlerin hem toplu olarak hem de cinsiyete ve yerleşim birimine göre okul dışında kalmayı etkileme durumlarını belirlerken öncelikle modelin varsayımları karşılayıp karşılamadığı ile ilgili değerler incelenmiş, model uyum değerlerini gösteren öncül analizler araştırmanın amaçları doğrultusunda y1llara göre sırasıyla verilmiştir.

Cinsiyete göre sosyoekonomik değişkenlerin okul dışında kalmasını etkileme durumunu belirlemek için yapılan Binary Lojistik Regresyonun model uyumluluğu ile ilgili analiz sonuçları:

DİE 2003 ve TÜİK 2011, 2016 y1lı verilerine göre cinsiyete göre sosyoekonomik değişkenlerin okul dışında kalmaya etkisine ilişkin model uyum analiz sonuçları aşağıda verilmiştir.

2003 yılı verilerinin model uyum analiz sonuçları: Modelde bağımsız değişkenler arasındaki korelasyon değerleri erkeklerde -0.619 ile +0.369 arasında, kızlarda ise -596 ile 
+0.320 arasında olduğu için modelin Çoklu Doğrusal Bağlantı Sorunu bulunmamaktadır. Model, altı bağımsız değişkeni içermektedir (yerleşim birimi, sosyal güvence, kişi başına kullanılabilir yıllık gelir, hanehalkı büyüklüğü, annenin ve babanın eğitim düzeyi). Tüm yordayıcıları içeren tam model istatistiksel olarak anlamlı bulunmuştur (erkeklerde $\beta=$ 1.022; Wald= 1195.903; $p=0.000 ; \operatorname{Exp}(B)=0.363$; k1zlarda: $\beta=-0.363$; Wald= 200.272; $p=$ 0.000; $\operatorname{Exp}(B)=0.696)$. Model değerleri erkek ve kız ayrımına göre modelin öğrenci olanlarla öğrenci olmayanları birbirinden ayırt edebildiğini göstermektedir. Bir bütün olarak model, ortaöğretim çağındaki erkek nüfusun öğrenci olmayan ile ilgili varyansın \%8.5'i (Cox ve Snell R Kare) ile \%12.4'ü (Nagelkerke R Kare) arasında bir kısmını açıklayabilmekte ve katılımcıların \%74.0’ünü doğru bir biçimde sınıflandırabilmektedir. Ortaöğretim çağındaki kız nüfusun öğrenci olmayan ile ilgili varyansın \%15.0’i (Cox ve Snell R Kare) ile \%21,2'si (Nagelkerke R Kare) arasında bir kısmını açıklayabilmekte ve katılımcıların \%69.1'ini doğru bir biçimde sınıflandırabilmektedir. Yordayıcı değişkenler analize girdiğinde Hosmer ve Lemeshow Testi sonucu anlamlıdır (erkek: $p=0.097$; kız: $p=$ 0.057). Elde edilen anlamlılık düzeyinin 0.05 'ten daha yüksek olması model-veri uyumunun yeterli düzeyde olmasıyla ilgili sorun olmadığını göstermektedir.

2011 yılı verilerin model uyum analiz sonuçları: Modelde bağımsız değişkenler arasındaki korelasyon değerleri erkeklerde -0.267 ile +0.376 arasında, kızlarda ise :-292 ile +0,382 arasında olduğu için modelin Çoklu Doğrusal Bağlantı Sorunu bulunmamaktadır. Model, altı bağımsız değişkeni içermektedir (yerleşim birimi, sosyal güvence, kişi başına kullanılabilir yıllık gelir, hanehalkı büyüklüğü, annenin ve babanın eğitim düzeyi). Tüm yordayıcıları içeren tam model istatistiksel olarak anlamlı bulunmuştur (erkeklerde $\beta=$ 1.488; Wald= 581.681; $\mathrm{p}=0.000 ; \operatorname{Exp}(\mathrm{B})=4.42$; kılarda: $\beta=-1.161 ;$ Wald $=415.581 ; \mathrm{p}=$ 0.000; $\operatorname{Exp}(B)=3.19)$. Model değerleri erkek ve kız ayrımına göre modelin öğrenci olanlarla öğrenci olmayanları birbirinden ayırt edebildiğini göstermektedir. Bir bütün olarak model, ortaöğretim çağındaki erkek nüfusun öğrenci olmayan ile ilgili varyansın \%9.7'si (Cox ve Snell R Kare) ile \%15.8'i (Nagelkerke R Kare) arasında bir kısmını açıklayabilmekte ve katılımcıların \%81.6'sını doğru bir biçimde sınıflandırabilmektedir. Ortaöğretim çağındaki k1z nüfusun öğrenci olmayan ile ilgili varyansın \%19.4'ü (Cox ve Snell R Kare) ile \%29.1'i (Nagelkerke R Kare) arasında bir kısmını açıklayabilmekte ve katılımcıların \%79.4'ini doğru bir biçimde sınıflandırabilmektedir. Yordayıcı değişkenler analize girdiğinde Hosmer ve Lemeshow Testi sonucu anlamlıdır (erkek: $p=0.892 ; \mathrm{k} 1 \mathrm{z}$ : $\mathrm{p}=0.526$ ). Anlamlılık 
düzeyinin yüksek olması model-veri uyumunun yeterli düzeyde olmasıyla ilgili sorun olmadığını göstermektedir.

2016 yılı verilerinin model uyum analiz sonuçları: Modelde bağımsız değişkenler arasındaki korelasyon değerleri erkeklerde -0.82 ile +0.414 arasında, kızlarda ise: -213 ile +0,412 arasında olduğu için modelin Çoklu Doğrusal Bağlantı Sorunu bulunmamaktadır. Model, altı bağımsız değişkeni içermektedir (yerleşim birimi, sosyal güvence, kişi başına kullanılabilir yıllık gelir, hanehalkı büyüklüğü, annenin ve babanın eğitim düzeyi). Tüm yordayıcıları içeren tam model istatistiksel olarak anlamlı bulunmuştur (erkeklerde $\beta=$ 1.509; Wald $=836.972 ; p=0.000 ; \operatorname{Exp}(B)=0.221$; k1zlarda: $\beta=1.337$; Wald $=658.617 ; p=$ $0.000 ; \operatorname{Exp}(B)=0.263)$. Model değerleri erkek ve kız ayrımına göre modelin öğrenci olanlarla öğrenci olmayanları birbirinden ayırt edebildiğini göstermektedir. Bir bütün olarak model, ortaöğretim çağındaki erkek nüfusun öğrenci olmayan ile ilgili varyansın \%4.9'u (Cox ve Snell R Kare) ile \%8.1'i (Nagelkerke R Kare) arasında bir kısmını açıklayabilmekte ve katılımcıların \%82.1'ini doğru bir biçimde sınıflandırabilmektedir. Ortaöğretim çağındaki k1z nüfusun öğrenci olmayan ile ilgili varyansın \%5.8'i (Cox ve Snell R Kare) ile \%9'u (Nagelkerke R Kare) arasında bir kısmını açıklayabilmekte ve katılımcıların \%79.7'sini doğru bir biçimde sınıflandırabilmektedir. Yordayıcı değişkenler analize girdiğinde Hosmer ve Lemeshow Testi sonucu anlamlıdır (erkek: $p=0.184$; kız: $p=0.107$ ). Anlamlılık düzeyinin yüksek olması model-veri uyumunun yeterli düzeyde olmasıyla ilgili sorun olmadığını göstermektedir.

\section{Bulgular}

Y1llara göre (2003, 2011 ve 2016) ortaöğretim çağındaki nüfusun cinsiyete göre öğrenci olma/olmama sayıları ve oranları Tablo 3'te verilmiş ve ayrıca görsel olarak karşılaştırma için Şekil 1'de grafik olarak sunulmuştur.

Tablo 3 incelendiğinde, ortaöğretim çağındaki nüfusun 2003 yılında toplam \%25.2'si, 2011 yılında \%21'i ve 2016 yılında ise \%22.2'si okul dışındadır. Okul dışında kalanların 2003 yılında \%63'ü, 2011 yılında \%54.7'si, 2016 yılında ise \%50.6's1 kızdır. Ortaöğretim çağındaki erkek ve kızların okul dışında kalma oranları Şekil 1'de verilmiştir. 
Tablo 3. Yıllara Göre 13-17 Yaş Nüfusun Cinsiyete Ayrımına Göre Öğrenci Olma Durumlarının Dă̆glımı

\begin{tabular}{|c|c|c|c|c|c|c|c|c|}
\hline \multirow[t]{3}{*}{ Yillar } & \multirow[t]{3}{*}{ Cinsiyet } & \multicolumn{2}{|c|}{ Öğrenci Değil } & \multicolumn{2}{|c|}{ Öğrenci } & \multicolumn{3}{|c|}{ Toplam } \\
\hline & & f & $\%$ & $\mathbf{f}$ & $\%$ & $\mathbf{f}$ & $\%$ & Öğrenci \\
\hline & & & & & & & & olmayan \% \\
\hline \multirow{3}{*}{2003} & Erkek & 1031 & 37.05 & 4443 & 53.89 & 5474 & 49.64 & 18.83 \\
\hline & $\mathrm{K}_{1 \mathrm{Z}}$ & 1752 & 62.95 & 3802 & 46.11 & 5554 & 50.36 & 31.54 \\
\hline & Toplam & 2783 & 25.24 & 8245 & 74.76 & 11028 & 100.00 & 25.24 \\
\hline \multirow{3}{*}{2011} & Erkek & 343 & 45.31 & 1490 & 52.39 & 1833 & 50.90 & 18.71 \\
\hline & $\mathrm{K} 1 \mathrm{z}$ & 414 & 54.69 & 1354 & 47.61 & 1768 & 49.10 & 23.42 \\
\hline & Toplam & 757 & 21.02 & 2844 & 78.98 & 3601 & 100.00 & 21.02 \\
\hline \multirow{3}{*}{2016} & Erkek & 448 & 49.45 & 1695 & 53.40 & 2143 & 52.52 & 20.91 \\
\hline & $\mathrm{K}_{1 \mathrm{z}}$ & 458 & 50.55 & 1479 & 46.60 & 1937 & 49.10 & 23.64 \\
\hline & Toplam & 906 & 22.21 & 3174 & 77.79 & 4080 & 100.00 & 22.21 \\
\hline
\end{tabular}

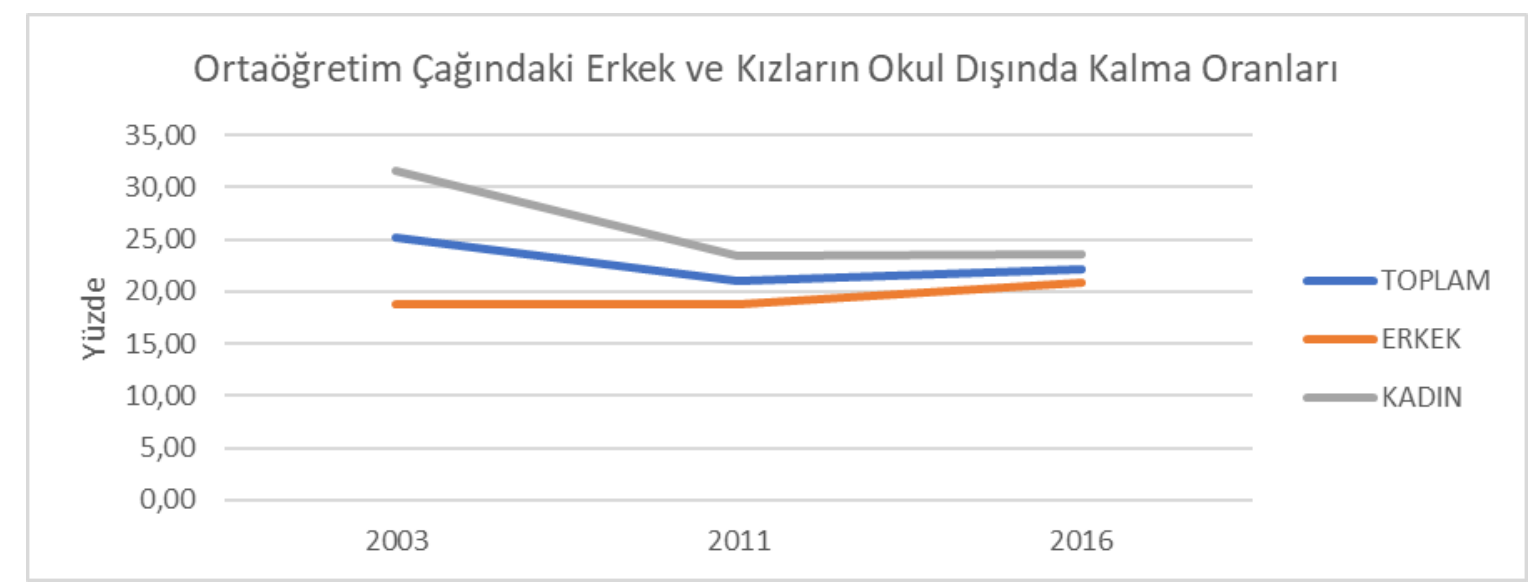

Şekil 1. Yıllara Göre Erkek ve Kızların Okul Dışında Kalma Oranları

Şekil 1 incelendiğinde, özellikle cinsiyetler (kız ve erkekler) arasındaki okul dışında kalma oranları arasındaki farkın azaldığı görülmektedir. Yıl bazında ortaöğretim çağındaki erkek ve kızların okul dışında kalma oranlarının 2011 yılına doğru düştüğü ve 2011 yılından sonra düşük oranda artış gösterdiği anlaşılmaktadır. 
Cinsiyete (kı/erkek) göre sosyoekonomik değişkenlerin okul dişında kalmaya etkisini belirlemek için yapılan Binary Lojistik Regresyon analiz sonuçları Tablo 4'te verilmiştir.

Tablo 4. 2003, 2011 ve 2016 Yılı Veri Analiz Sonuçlarına Göre Sosyo-Ekonomik Değişkenlerin Erkek ve Kızların Okul Dışında Kalmasını Etkileme Durumu

\begin{tabular}{|c|c|c|c|c|c|c|c|c|c|}
\hline \multirow{2}{*}{$\begin{array}{l}\text { Bağımsız } \\
\text { Değişkenler }\end{array}$} & \multirow[t]{2}{*}{ Yil } & \multicolumn{4}{|c|}{ Erkek } & \multicolumn{4}{|c|}{ Kız } \\
\hline & & $\boldsymbol{\beta}$ & Wald & $p$ & $\operatorname{Exp}(B)$ & $\boldsymbol{\beta}$ & Wald & $P$ & $\operatorname{Exp}(B)$ \\
\hline \multirow[t]{3}{*}{ Yerleşim Birimi } & 2003 & 0.23 & 24.47 & 0.00 & 1.26 & 0.29 & 50.07 & 0.00 & 1.33 \\
\hline & 2011 & 0.10 & 0.48 & 0.49 & 1.10 & 0.42 & 9.83 & 0.00 & 1.52 \\
\hline & 2003 & 0.50 & 37.91 & 0.00 & 1.65 & 0.53 & 54.12 & 0.00 & 1.71 \\
\hline \multirow[t]{3}{*}{ Sağlık Güvencesi } & 2011 & 0.36 & 13.21 & 0.00 & 1.44 & 0.34 & 12.28 & 0.00 & 1.41 \\
\hline & 2016 & 0.04 & 5.19 & 0.02 & 1.03 & 0.02 & 1.18 & 0.28 & 1.02 \\
\hline & 2003 & 0.47 & 68.33 & 0.00 & 1.60 & 0.31 & 43.83 & 0.00 & 1.37 \\
\hline \multirow{3}{*}{$\begin{array}{l}\text { Anne Eğitim } \\
\text { Düzeyi }\end{array}$} & 2011 & 0.42 & 13.93 & 0.00 & 1.52 & 0.44 & 14.44 & 0.00 & 1.54 \\
\hline & 2016 & 0.03 & 11.61 & 0.00 & 1.03 & 0.02 & 5.15 & 0.02 & 1.02 \\
\hline & 2003 & 0.24 & 10.89 & 0.00 & 1.27 & 0.66 & 104.66 & 0.00 & 1.93 \\
\hline \multirow{2}{*}{$\begin{array}{l}\text { Baba Eğitim } \\
\text { Düzeyi }\end{array}$} & 2011 & 0.47 & 29.05 & 0.00 & 1.59 & 0.44 & 23.06 & 0.00 & 1.56 \\
\hline & 2016 & 0.01 & 6.98 & 0.01 & 1.01 & 0.01 & 4.59 & 0.03 & 1.01 \\
\hline \multirow{4}{*}{$\begin{array}{l}\text { Hanehalkı } \\
\text { Büyüklüğü }\end{array}$} & 2003 & 0.03 & 0.61 & 0.43 & 1.03 & 0.06 & 3.87 & 0.05 & 1.07 \\
\hline & 2011 & 0.07 & 1.93 & 0.16 & 1.08 & 0.31 & 37.18 & 0.00 & 1.36 \\
\hline & 2016 & 0.09 & 15.25 & 0.00 & 1.10 & 0.10 & 21.05 & 0.00 & 1.11 \\
\hline & 2003 & 0.07 & 4.34 & 0.04 & 1.07 & 0.17 & 36.40 & 0.00 & 1.18 \\
\hline \multirow{2}{*}{$\begin{array}{l}\text { Gelir (Kişi Başı } \\
\text { Yıllık) }\end{array}$} & 2011 & 0.05 & 0.62 & 0.43 & 1.05 & 0.03 & 0.22 & 0.64 & 1.03 \\
\hline & 2016 & 0.11 & 5.48 & 0.02 & 1.11 & 0.19 & 17.19 & 0.00 & 1.20 \\
\hline Engellilik & 2011 & 1.31 & 7.90 & 0.01 & 3.70 & 0.94 & 3.83 & 0.05 & 2.56 \\
\hline Durumu & 2016 & 1.77 & 36.12 & 0.00 & 5.88 & 1.72 & 21.44 & 0.00 & 5.56 \\
\hline
\end{tabular}




\begin{tabular}{lccccccccc}
\hline \multirow{2}{*}{$\begin{array}{l}\text { Bağımsız } \\
\text { Değişkenler }\end{array}$} & Yıl & \multicolumn{4}{c}{ Erkek } & \multicolumn{5}{c}{ Kız } \\
\cline { 3 - 10 } & & $\boldsymbol{\beta}$ & Wald & $\boldsymbol{p}$ & $\boldsymbol{E x p}(\boldsymbol{B})$ & $\boldsymbol{\beta}$ & Wald & $\boldsymbol{P}$ & $\boldsymbol{E x p}(\boldsymbol{B})$ \\
\hline \multirow{3}{*}{ Sabit } & 2003 & 0.54 & 5.29 & 0.02 & 1.72 & 2.20 & 105.16 & 0.00 & 9.01 \\
& 2011 & 2.13 & 4.23 & 0.04 & 8.43 & 1.49 & 2.07 & 0.15 & 4.43 \\
& 2016 & 2.41 & 13.55 & 0.00 & 11.11 & 2.35 & 8.69 & 0.00 & 10.45 \\
\hline
\end{tabular}

2003 ve 2011 yılı veri analiz sonuçları incelendiğinde; kırda yaşayan ortaöğretim çağındaki erkek ve kızların, kentte yaşayan erkek ve kızlara göre okul dışında kalma olasılıkları daha fazladır. Tablo 4 incelendiğinde, 2003 yılı veri analiz sonuçlarına göre ortaöğretim çağındaki erkek nüfusun okul dışında kalma olasılığını yordamada yerleşim birimi $(\beta=0.23 ; \operatorname{Exp}(B)=1.26)$ anlamlı $(p<0.05)$ bir yordayıcı iken, 2011 veri analiz sonuçlarına göre anlamlı bir yordayıcı değildir $(p=0.49>0.05)$. 2003 verilerine göre modeldeki diğer bağımsız değişkenler kontrol altında tutulduğunda, kentte yaşayan erkeklere göre kırsalda yaşayan erkeklerin okul dışında kalma olasılı̆̆ 1.26 kat daha fazladır. Başka bir deyimle kentte yaşayan ortaöğretim çağındaki erkeklerden 1 kişi okul dışında kalmasına karşılık, kırda yaşayan ortaöğretim çağındaki erkeklerden 1.26 kişinin okul dışında kalması olasıdır. 2011 verilerinde ise kentte ve kırda yaşayan erkeklerin okul dışında kalma olasılıkları arasında anlamlı bir farklılık yoktur. Yerleşim birimi, 2003 yılı $(\beta=0.29 ; \operatorname{Exp}(B)=1.33)$ ve 2011 y1lı $(\beta=0.42 ; \operatorname{Exp}(B)=1.52)$ verilerine göre ortaöğretim çağındaki kız nüfusun okul dışında kalma olasılığını yordamada anlamlı bir değişkendir $(p<0.05)$. Modeldeki diğer bağımsız değişkenler kontrol altında tutulduğunda, kentlerdeki kız çocuklarına göre kırsalda yaşayan kızların okul dışında kalma olasılığı 2003 yılı için 1.33 kat, 2011 yılı için 1.52 kat daha fazladır. 2011 yılında yerleşim biriminin ortaöğretim çağındaki kızların okul dışında kalmasında etkililiği artmıştır. Yerleşim yeri erkeklerden çok kızların okul dışında kalmasında etkili bir değişkendir.

Cinsiyet ayrımına göre sağlık güvencesinin okul dışında kalmayı yordama durumuna ilişkin 2003, 2011 ve 2016 yılı veri analiz sonuçları incelendiğinde; sağlık güvencesi olmayan ortaöğretim çağındaki erkeklerin, sağlık güvencesi olan erkeklere göre okul dışında kalma olasılıkları daha fazladır. Tablo 4 incelendiğinde, 2003 yılı $(\beta=0.50 ; \operatorname{Exp}(B)=1.65)$, 2011 y1lı $(\beta=0.36 ; \operatorname{Exp}(B)=1.44)$ ve 2016 y1lı $(\beta=0.04 ; \operatorname{Exp}(B)=1.03)$ verilerine göre sağlık güvencesinin (zorunlu ve isteğe bağlı sigortalı, yeşil kartl1, sağl1k güvencesi yok) ortaöğretim çağındaki erkek nüfusun okul dışında kalmasını yordamada anlamlı $(p \leq 0.05)$ bir 
değişken olduğu görülmüştür. Ortaöğretim çağındaki sağlı güvencesi olmayan erkeklerin, yeşil kartlı erkeklere göre okul dışında kalma olasılığı 2003 yılı için 1.65 kat, 2011 yılı için 1.44 kat ve 2016 yılı için 1.03 kat daha fazladır. Yine ortaöğretim çağındaki yeşil kartlı bir erkeğin, zorunlu ve isteğe bağlı sigortalı olan erkeklere göre okul dışında kalma olasılığ1 2003 y1lı için 1.65 kat, 2011 y1lı için 1.44 kat ve 2016 yılı için 1.03 kat daha fazladır.

Sağlık güvencesi, ortaöğretim çağındaki kızların okul dışında kalmasını yordamada 2016 yılı verilerine göre anlamlı değil iken, 2003 ve 2011 yılı verilerine göre anlamlı bir yordayıcıdır. Bu yıllara göre, ortaöğretim çağındaki sağlık güvencesi olmayan kızların, sağlık güvencesi olan kızlara göre okul dışında kalma olasılıkları daha fazladır. Tablo 4'te, 2003 y1lı $(\beta=0.53 ; \operatorname{Exp}(B)=1.71), 2011$ y1lı $(\beta=0.34 ; \operatorname{Exp}(B)=1.41)$ ve 2016 y1l1 $(\beta=0.02 ;$ $\operatorname{Exp}(B)=1.02)$ verilerine göre sağlık güvencesinin ortaöğretim çağındaki kız nüfusun okul dışında kalmasını yordamada anlamlı $(p \leq 0.05)$ bir değişken olduğu görülmüştür. Sağlık güvencesi olmayan ortaöğretim çağındaki kız çocuklarının, yeşil kartlı kızlara göre okul dışında kalma olasılığı 2003 yılı için 1.71 kat, 2011 y1lı için 1.41 kat ve 2016 y1lı için 1.02 kat daha fazladır. Sağlık güvencesi durumundaki (Zorunlu ve isteğe bağlı sigortalı, yeşil kartlı, herhangi bir güvencesi yok) azalma, okul dışında kalma olasılığını arttırmaktadır. Sağlık güvencesi olmayan ortaöğretim çağındaki erkek ve kızların, yeşil kartlı hemcinslerine göre okul dışında kalma olasılıkları daha yüksektir. Benzer şekilde, yeşil kartlı erkek ve kızların okul dışında kalma olasılıkları zorunlu ve isteğe bağlı sigortalı olan hemcinslerine göre daha fazladır. Sağlık güvencesinin ortaöğretim çağındaki kız ve erkeklerin okul dışında kalmasında etkili bir değişken olduğu ancak 2003 verileri dışında özellikle erkeklerin okul dışında kalmasında daha fazla etkili olduğu görülmektedir.

Cinsiyet ayrımına göre anne eğitim düzeyinin okul dışında kalmayı yordama durumuna ilişkin 2003, 2011 ve 2016 y1lı veri analiz sonuçları incelendiğinde; anne eğitim düzeyi düşük ortaöğretim çağındaki erkek ve kızların, anne eğitim düzeyi yüksek olan hemcinslerine göre okul dişında kalma olasılıkları daha fazladır. Tablo 4 incelendiğinde, 2003 y1lı $(\beta=0.47 ; \operatorname{Exp}(B)=1.60), 2011$ y1lı $(\beta=0.42 ; \operatorname{Exp}(B)=1.52)$ ve 2016 y1lı $(\beta=0.03 ;$ $\operatorname{Exp}(B)=1.03)$ verilerine göre anne eğitim düzeyinin her üç yıl için de ortaöğretim çağındaki erkek nüfusun okul dışında kalmasını yordamada anlamlı $(p \leq 0.05)$ bir değişken olduğu görülmüştür. Anne eğitim düzeyindeki (yükseköğretim mezunu, lise ve dengi okul mezunu, ilköğretim mezunu, ilkokul mezunu, mezun değil) bir birimlik azalış, ortaöğretim çağındaki erkeklerin okul dışında kalma olasılığını 2003 yılı için 1.60 kat, 2011 yılı için 1.52 kat ve 2016 yılı için 1.03 kat arttırmaktadır. Yani ortaöğretim çağındaki nüfusta, annesi ilkokul 
mezunu erkeklerin, annesi ilköğretim mezunu olan erkeklere göre okul dışında kalma olasılığı 2003 y1lı için 1.60 kat, 2011 yılı için 1.52 kat ve 2016 yılı için 1.03 kat daha fazladır. Tablo 4 incelendiğinde, 2003 yılı $(\beta=0.31 ; \operatorname{Exp}(B)=1.37), 2011$ y1lı $(\beta=0.44$; $\operatorname{Exp}(B)=1.54)$ ve 2016 yılı $(\beta=0.02 ; \operatorname{Exp}(B)=1.02)$ verilerine göre anne eğitim düzeyi ortaöğretim çağındaki kız nüfusun okul dışında kalmasını yordamada anlamlı $(p \leq 0.05)$ bir değişkendir. Anne eğitim düzeyindeki bir birimlik azalış, ortaöğretim çağındaki kız çocuklarının okul dışında kalma olasılığını 2003 yılı için 1.37 kat, 2011 yılı için 1.54 kat ve 2016 y1lı için 1.02 kat arttırmaktadır. Yani ortaöğretim çağındaki nüfusta, annesi mezun olmayan kız çocuklarının, annesi ilkokul mezunu olan kızlara göre okul dışında kalma olasılığ1 2003 yılı için 1.37 kat, 2011 yılı için 1.54 kat ve 2016 yılı için 1.02 kat daha fazladır. Anne eğitim düzeyi, 2003 yılı dışında, kızlardan daha çok erkeklerin okul dışında kalmasında etkili bir değişkendir.

Cinsiyet ayrımına göre baba eğitim düzeyinin okul dışında kalmayı yordama durumuna ilişkin 2003, 2011 ve 2016 y1lı veri analiz sonuçları incelendiğinde; baba eğitim düzeyi düşük ortaöğretim çağındaki erkek ve kızların, baba eğitim düzeyi yüksek olan hemcinslerine göre okul dişında kalma olasılıkları daha fazladır. Tablo 4'e bakıldığında, 2003 y1lı $(\beta=0.24 ; \operatorname{Exp}(B)=1.27), 2011$ y1lı $(\beta=0.47 ; \operatorname{Exp}(B)=1.59)$ ve 2016 y1l1 $(\beta=0.01 ;$ $\operatorname{Exp}(B)=1.01)$ verilerine göre baba eğitim düzeyinin ortaöğretim çağındaki erkek nüfusun okul dışında kalmasını yordamada anlamlı $(p \leq 0.05)$ bir değişken olduğu görülmüştür. Baba eğitim düzeyindeki bir birimlik azalış, ortaöğretim çağındaki erkeklerin okul dışında kalma olasılığını 2003 y1lı için 1.27 kat, 2011 y1lı için 1.59 kat ve 2016 yılı için 1.01 kat arttırmaktadır. Yani ortaöğretim çağındaki nüfusta, babası lise ve dengi okul mezunu olan erkeklerin, babası yükseköğretim mezunu olan erkeklere göre okul dışında kalma olasılığı 2003 y1lı için 1.27 kat, 2011 y1lı için 1.59 kat ve 2016 y1lı için 1.01 kat daha fazladır. Tablo 4 incelendiğinde, 2003 yılı $(\beta=0.66 ; \operatorname{Exp}(B)=1.93), 2011$ y1lı $(\beta=0.44 ; \operatorname{Exp}(B)=1.56)$ ve 2016 y1lı $(\beta=0.01 ; \operatorname{Exp}(B)=1.01)$ verilerine göre baba eğitim düzeyinin ortaöğretim çağındaki kız nüfusun okul dışında kalmasını yordamada da anlamlı $(p \leq 0.05)$ bir değişken olduğu görülmektedir. Baba eğitim düzeyindeki bir birimlik azalış, ortaöğretim çağındaki kız çocuklarının okul dışında kalma olasılığını 2003 yılı için 1.93 kat, 2011 yılı için 1.56 kat ve 2016 yılı için 1.01 kat arttırmaktadır. Yani ortaöğretim çağındaki nüfusta, babası mezun olmayan kızların, babası ilkokul mezunu olan kızlara göre okul dışında kalma olasılığı 2003 y1lı için 1.93 kat, 2011 yılı için 1.56 kat ve 2016 yılı için 1.01 kat daha fazladır. Baba eğitim düzeyi yüksek olan ortaöğretim çağındaki erkekler ve kızların, baba eğitim düzeyi düşük 
hemcinslerine oranla okul dışında kalma olasılıkları daha düşüktür. Baba eğitim düzeyi arttıkça okul dışında kalma olasılığı azalmaktadır. Baba eğitim düzeyi, 2003 yılında erkeklerden daha çok kızların okul dışında kalmasında etkili bir değişkendir.

Cinsiyet ayrımına göre hanehalkı büyüklügünün okul dışında kalmayı yordama durumuna ilişkin 2003, 2011 ve 2016 y1lı veri analiz sonuçları incelendiğinde; hanehalk1 büyüklüğü düşük olan ortaöğretim çağındaki erkek ve kızların, hanehalkı büyüklüğü yüksek olan hemcinslerine göre okul dışında kalma olasılıkları daha fazladır. Tablo 4'te, hanehalkı büyüklüğünün ortaöğretim çağındaki erkek nüfusun okul dışında kalmasını yordamada 2003 ve 2011 y1lı verilerine göre anlamlı olmadığ $1(p=0.43>0.05)$, ancak 2016 y1lı $(\beta=0.09$; $\operatorname{Exp}(B)=1.10)$ verilerine göre anlamlı $(p \leq 0.05)$ olduğu görülmektedir. Hanehalk1 büyüklüğündeki (üç ve daha az “1”, dört kişi “2”, beş kişi “"3”, altı kişi “4”, yedi ve sekiz kişi “5” ve dokuz kişi ve fazlası “6”) bir birimlik artış, ortaöğretim çağındaki erkeklerin okul dışında kalma olasılığını 2003 ve 2011 yılı için etkilemez iken, 2016 yılı için 1.10 kat arttırmaktadır. Yani 2016 yılı için ortaöğretim çağındaki nüfusta, beş kişilik bir hanedeki erkeklerin, dört kişilik bir hanedeki erkeklere göre okul dışında kalma olasılığı 1.10 kat daha fazladır. Tablo 4 incelendiğinde, 2003 y1lı $(\beta=0.06 ; \operatorname{Exp}(B)=1.07), 2011$ y1lı $(\beta=0.31$; $\operatorname{Exp}(B)=1.36)$ ve 2016 yılı $(\beta=0.10 ; \operatorname{Exp}(B)=1.11)$ verilerine göre hanehalkı büyüklüğünün ortaöğretim çağındaki kız nüfusun okul dışında kalmasını yordamada anlamlı $(p \leq 0.05)$ bir değişken olduğu görülmektedir. Hanehalkı büyüklüğündeki bir birimlik artış, ortaöğretim çağındaki kız çocuklarının okul dışında kalma olasılığını 2003 yılı için 1.07 kat, 2011 yılı için 1.36 kat ve 2016 yılı için 1.11 kat arttırmaktadır. Hanedeki fert sayısı özellikle kız çocuklarının okul dışında kalma olasılığını etkilemektedir.

Cinsiyet ayrımına göre kişibaşı yıllık gelirin okul dışında kalmayı yordama durumuna ilişkin 2003 ve 2016 yılı veri analiz sonuçları incelendiğinde; kişibaşı yıllık geliri düşük olan ortaöğretim çağındaki erkek ve kızların, kişibaşı yıllık geliri yüksek olan hemcinslerine göre okul dışında kalma olasılıkları daha fazladır. Kişibaşı yıllık gelir, 2011 yılı için erkek ve kızların okul dışında kalma olasılığını etkilememektedir. Tablo 4 incelendiğinde, 2003 y1lı $(\beta=0.07 ; \operatorname{Exp}(B)=1.07 ; p=0.04<0.05)$ ile 2016 y1lı $(\beta=0.11$; $\operatorname{Exp}(B)=1.11 ; \mathrm{p}=0.02<0.05)$ verilerine göre kişibaşı yıllık gelir ortaöğretim çağındaki erkek nüfusun okul dışında kalmasını yordamada anlamlı bir değişken iken 2011 yılı $(\beta=0.01$; $\operatorname{Exp}(B)=1.01)$ verilerine göre anlamlı bir değişken olmadığı $(\mathrm{p}=0.43>0.05)$ görülmektedir. Kişibaşı yıllık gelirdeki bir birimlik azalış, ortaöğretim çağındaki erkeklerin okul dışında kalma olasılığını 2003 yılı için 1.07 kat ve 2016 y1lı için 1.11 kat arttırmaktadır. Yani 
ortaöğretim çağındaki nüfusta, kişibaşı yıllık geliri artan erkeklerin, okul dışında kalma olasılıkları düşmektedir. Tablo 4 incelendiğinde, 2003 yılı $(\beta=0.17 ; \quad \operatorname{Exp}(B)=1.18$; $p=0.00<0.05)$ ile 2016 y1lı $(\beta=0.19 ; \operatorname{Exp}(B)=1.20 ; \mathrm{p}=0.00<0.05)$ verilerine göre kişibaş1 yıllık gelirin, ortaöğretim çağındaki kız nüfusun okul dışında kalmasını yordamada anlamlı olduğu, 2011 yılı verilerine göre ise anlamlı olmadığı $(\mathrm{p}=0.64>0.05)$ görülmektedir. Kişibaşı yıllık gelirdeki bir birimlik azalış, ortaöğretim çağındaki kızların okul dişında kalma olasılığını 2003 yılı için 1.18 kat, 2016 yılı için 1.20 kat arttırmaktadır. Yani ortaöğretim çağındaki nüfusta, kişibaşı yıllık geliri artan kızların, okul dışında kalma olasılıkları düşmektedir. Kişibaşı yıllık gelir azaldıkça okul dışında kalma olasılığı artmaktadır. Kişibaşı yıllık gelir erkeklerden çok kızların okul dışında kalmasında etkili bir değişkendir. 2003 yılından 2016 yılına doğru, kişibaşı yıllık gelirin okul dışında kalma olasılığı üzerindeki etkisi artmıştır.

Cinsiyet ayrımına göre engelli olma durumunun okul dışında kalmayı yordamasına ilişkin 2011 ve 2016 yılı veri analiz sonuçları incelendiğinde; engeli olmayan ortaöğretim çağındaki erkek ve kızların, engeli olan hemcinslerine göre okul dışında kalma olasılıkları daha azdır. Tablo 4 incelendiğinde, 2011 yılı $(\beta=1.31 ; \operatorname{Exp}(B)=3.70)$ ve 2016 y1lı $(\beta=1.77$; $\operatorname{Exp}(B)=5.88)$ verilerine göre ortaöğretim çağındaki engelli erkeklerin okul dışında kalmasını yordamada anlamlı $(p \leq 0.05)$ bir değişken olduğu görülmüştür. Ortaöğretim çağındaki engelli erkeklerin, engeli olmayan erkeklere göre okul dışında kalma olasılığı 2011 yılı için 3.70 kat ve 2016 yılı için 5.88 kat daha fazladır. Erkeklerde engelli olma durumu okul dışında kalma olasılığı da artmaktadır. Tablo 4 incelendiğinde, 2011 yılı $(\beta=0.94 ; \operatorname{Exp}(B)=2.56)$ ile 2016 yılı $(\beta=1.72 ; \operatorname{Exp}(B)=5.56)$ verilerine göre engelli olma durumunun ortaöğretim çağındaki kızların okul dışında kalmasını yordamada anlamlı $(p \leq 0.05)$ bir değişken olduğu görülmüştür. Ortaöğretim çağındaki engelli kızların, engeli olmayan kızlara göre okul dışında kalma olasılığı 2011 yılı için 2.56 kat ve 2016 yılı için 5.56 kat daha fazladır. Kız çocuklarında engel durumu arttıkça okul dışında kalma olasılığı da artmaktadır. Ortaöğretim çağındaki engeli olan erkek ve kızların, engeli olmayan hemcinslerine oranla okul dışında kalma olasılıkları daha yüksektir. 2011 ve 2016 yılı verileri karşılaştırıldığında, ortaöğretim çağ nüfusunda, engeli olanların okul dışında kalma olasılıklarının azalmaktan çok iki katından fazla arttığı ve engelli erkeklerin engelli kızlara göre okul dışında kalma olasılıklarının daha da fazla arttığı anlaşılmaktadır. 


\section{Tartışma ve Sonuç}

Verilerin çözümlemesinden okul dışında kalmada etkili bireysel değişkenlerin başında engelli olma ve cinsiyet gelmektedir. 2003, 2011 ve 2016 yılı verilerinin tümünde k1z çocuklarının okul dışında kalma oranları erkeklerden daha fazladır. Kırsalda yaşayan, sosyal güvencesi olmayan, anne ve baba eğitim düzeyi düşük olan, yoksul ve kalabalık ailelerdeki engelli kızların okul dışında kalma olasılı̆̆ı en fazladır.

Analizlerde, engelli olma durumunun okul dışında kalmada en yüksek yordayıcı olduğu anlaşılmıştır. Engeli olanların engeli olmayanlara oranla okul dışında kalma olasılıkları, 2011 ve 2016 verilerinde sirasıyla, 2.74 ve 5.56 kat daha fazladır. Bu durumun, Birleşmiş Milletler Engelli Hakları Sözleşmesinde vurgulanan birçok alanda, engellilere yönelik her türlü ayrımcılığın etkili olduğu düşünülmektedir. Gelişmiş ülke örneklerinde engelli çocuklar şartlar elverdiğinde okulda kaynaştırmalı eğitime alınmakta, uzmanların tespit ettiği çocuklara ise özel eğitim hizmetleri ücretsiz sunulmaktadır. Türkiye'de engelli çocuklar için özellikle ilköğretim okullarının fiziksel olanaklar ve öğretmen sayısı açısından yeterli olmaması, özel eğitim hizmetinin diğer ülkelere göre daha az sayıda kişiye ulaşması ve bu hizmetlerin ücretli olması, engeli olan çocukların okul dışında kalmalarına neden olabilmektedir (Genç ve Orhan, 2015). Ayrıca bu durum Çağlar'ın (2009) belirttiği gibi, engelli çocuğundan bir gelecek beklentisi olmayan, onlardan akademik bir başarı, ekonomik bir yarar beklemeyen ailelerin, zorunlu olmadıkça çocuklarını okula göndermeme eğiliminde olmalarından ve engelli çocukların ulaşım, beslenme vb. harcamalarının fazlalığından kaynaklanıyor olabilir. Yine okul dışında kalma riski taşıyan çocukların saptandığ çalışmalarda engelli olanlar ön plana çıkmaktadır (Hillman, 2014).

Alanyazın incelendiğinde kız çocuklarının erken yaşta yetişkin rollerine girmesi (anneye ev işlerinde yardım etme, kardeşlerine bakma) (Adıgüzel, 2013; Hoşgörür ve Polat, 2015; Küçüker, 2018; Tunç, 2009; UNICEF, 2017); kız çocuklarının erken ergenliğe girme gerekçesiyle evliliğe zorlanması (Adıgüzel, 2013; Dilli, 2006; Tunç, 2009); kızların okuma ve yazmayı öğrenmesinin yeterli görülerek kız çocuklarına evlenince kocaları bakar düşüncesi (Dilli, 2006; Özdemir, Erkan, Karip, Sezgin ve Şirin, 2010; Tunç, 2009); ailelerin erkek çocukları kızlara göre önde tutan geleneksel önyargıları (Bakış, Levent, İnsel ve Polat, 2009; Özdemir ve diğerleri, 2010; Tunç, 2009); ebeveynlerin akraba ve aile büyüklerince kınanmaları ve ayıplanmaları (Adıgüzel, 2013; Tunç, 2009); kızların geleneksel değerleri ve etik ilkeleri ihlal edeceği endişesi (Tunç, 2009); tutucu ailelerin karma eğitimi sorun etmesi (Bora, 2012; Tunç, 2009) gibi nedenlerle kendi istekleri dışında okul dışında kaldıkları 
vurgulanmaktadır. $\mathrm{Bu}$ nedenler araştırmanın bulgularını desteklemektedir. Toplumsal cinsiyet algılarının yerleşim yerine göre farklılık gösterdiği, kırsalda yaşayan kız ve erkeklerin kentteki akranlarına göre daha fazla olumsuz etkilendikleri anlaşılmıştır. Bu durum kırsalda yaşayan ailelerin eğitim düzeylerinin düşüklüğü, büyük çoğunluğunun tarım ve hayvancılık ile geçimlerini sağlaması ve dini anlamda daha tutucu düşünce yapısına sahip olduklarını düşündürmektedir. Kara ve Gürhan'a (2013) göre, eşitsizliğin yeniden üretildiği din kurumu da toplumsal cinsiyet eşitsizliğini doğallaştırmada "tanrısal bir olanak" olarak işlev görmektedir.

Kır ve kentte yaşayan ortaöğretim çağındaki nüfusun okul dışında kalma olasılıkları arasında anlamlı farklılık olduğu, özellikle kırdaki çocukların kentteki çocuklardan daha fazla okul dışında kaldıkları bulunmuştur. Yerleşim yerleri arasındaki bu farklılık, Kocakurt'un (2016) bulgularına göre, Türkiye'de tüm eğitim düzeylerinde, özellikle lise düzeyinde okul, öğretmen ve derslik sayısının en az olduğu yerlerin kırsal alanlar olması, kırsalda doğum oranının yüksek, sosyoekonomik gelişmişlik düzeyinin düşük ve kırsaldakilerin yoksulluk sınırında bulunmaları, kırsaldaki nüfusun geçim kaynağının tarım ve hayvancılığa bağlı olması dolayısıyla çocukların ev içinde ve/veya dışında çalıştırılmaları, kırsaldaki yetişkin nüfusun eğitim düzeyinin düşük olması bunun en önemli nedenleri arasında gösterilebilir. Ayrıca Soydan'ın (2015) belirttiği gibi, taşrada çalışan öğretmenler için uygun eğitsel ve yaşamsal olanaklar oluşturmanın zorluğuna bağlı olarak nitelikli öğretmenleri bu bölgelerde tutmakta yaşanan sorunlar, taşrada nitelikli bir eğitim sisteminin oluşturulamamasının en öne çıkan nedenleri arasındadır. Ancak bu araştırmanın sonuçları, Gümüş’ün (2014) çeşitli bireysel ve toplum düzeyindeki değişskenler kontrol altına alındıktan sonra kır-kent ayrımının önemli ölçüde çocukların okula katılımını etkilemediği bulgusunu desteklememektedir. Gümüş (2014), kır ve kentteki çocukların okula katılımı açısından farklılıkların yalnızca bulundukları yerden kaynaklanmadığını, daha çok hane ve toplum düzeyindeki eşitsizliklerden kaynaklanmış olabileceğini vurgulamıştır.

Hanehalkı büyüklüğü ve aile yapısı, hanedeki bireylerin gelir ve diğer kaynaklardan yararlanma oranı üzerinde belirleyici bir etkiye sahiptir. Araştırmanın verilerine göre, hanehalkı büyüklüğü arttıkça okul dışında kalma olasılığı da artmaktadır. Sosyoekonomik koşulları elverişsiz olan ebeveynlerin çocuk sayısının fazlalığı, çocukların eğitsel gereksinimlerini finanse etmede sorun yaşanmakta ve çocuklarıyla birebir ilgilenememektedirler (Soydan, 2015). Araştırmanın bulguları önceki araştırmaların bulgularını desteklemektedir (Beatty, Neisser, Trent ve Heubert, 2001; Cemalcılar, Gökşen 
ve Çelik, 2012; Gökşen, Cemalcılar ve Gürlesel, 2006; Gümüş, 2014; MEB, 2013; Özdemir ve diğerleri, 2010; Şimşek, 2011). Fakat bulgular Mike, Nakajjo ve Isoke'in (2016), daha büyük hanelerdeki çocukların okulu bırakma olasılıklarının daha küçük hanelerde yaşayan çocuklardan daha az olduğu ve ilişkilerin istatistiksel olarak anlamlı olduğu şeklindeki bulgularıyla uyumlu değildir. $\mathrm{Bu}$ farkın daha büyük ailelere verilen devlet desteğinden kaynaklandığı düşünülmektedir. Bir çocuğun eve gelir getiren kendisinden büyük kardeşlerinin olması da okul dışında kalma olasılığını azaltabilmektedir. Hanehalkı büyüklüğü arttıkça, çocukların kitap okuyup ders çalışabilmeleri için gerekli olan sessiz, sıcak ve rahatsız edilmeyeceği bir çalışma ortamı oluşturma olanağı azalmaktadır. Hanehalkı büyüklüğü arttıkça bireylerin ortalama tüketim harcamaları azalmakta ve en yoksul aileler öncelikle eğitim harcamalarında kesinti yapmaktadırlar.

Anne ve babanın eğitim düzeyi okul dışında kalmayı yordamada etkili değişkenlerdir. Anne ve baba eğitim düzeyi arttıkça okul dışında kalma olasılığı azalmaktadır. Araştırmanın bulguları önceki araştırmaların bulgularını desteklemektedir (Bakış ve diğerleri, 2009; Bora, 2012; Gökşen ve diğerleri, 2006; Gümüş, 2014; Hoşgörür ve Polat, 2015; Özbaş, 2012; Pehlivan, 2006). Eğitimli ebeveynlerin, çocuklarıyla geçirdikleri zamanın eğitimsiz emsallerine göre daha fazla olmasıyla çocuklarının akademik gelişimlerini izleyebilmeleri, denetleyebilmeleri ve çocuklarına akademik çalışmalarında daha etkili yardım edebilmeleri daha olasıdır. Eğitim düzeyi yüksek olan ebeveynler çocuklarının başarımını yapıcı olarak etkileyecek şekilde, evlerinde zengin okuma kaynakları ve ortamları oluşturma çabası içindedirler. Ek olarak çocuklarından beklentileri de daha yüksektir (Gülleroğlu, Demir ve Demirtaşl1, 2014). Çocuklarından eğitim beklentileri yüksek olan ebeveynler, çocuklarına ders dişı etkinliklere katılmaları yönünde ilham vermekte, öğretmenlerle daha çok iletişim kurmakta, öğretmenlerle kurulan iyi ilişkiler çocukların güdülenme olasılığını arttırmakta ve öğretmenler de öğrenciler ile ilgili sorunların üstesinden gelmede ebeveynler ile işbirliğini kolaylaştırmaktadır (Cui, 2014). Eğitimli ebeveynler, çocuklarının eğitimlerinin olası getirilerinin daha fazla farkındadır ve çocuklarının yüksek gelir getiren etkinliklerde bulunmaları için gereken bilgi ve sosyal ağlara erişme olasılıkları da daha yüksektir. Ayrıca Özel ve Zelyurt'un (2016) ifadesiyle, yüksek ebeveyn eğitimi, ebeveynlerin çocuklarını daha iyi tanımalarını kolaylaştırmakta, çocuklarıyla olan ilişkilerini daha sağlıklı ve etkili duruma dönüştürerek yapıcı yönde etkilemektedir. Schneider, Marschall, Teske ve Roch'a (1998) göre, daha az eğitimli ebeveynler, öğrenci başarımını değerlendirmenin daha soyut ve öznel yollarından (örneğin, 
öğrenci portföylerinden) daha çok, ölçünlendirilmiş testlerdeki yüksek puanlara yansıyan, akademik başarıma önem veriler. Çünkü onlar için testlerdeki güçlü başarım, iyi kolejlere ve iyi işlere erişimle ilişkilendirilmektedir. Daha az eğitimli ebeveynler, sınıfta daha fazla disiplin isteme eğilimindedirler.

Sağlık güvencesi (zorunlu ve isteğe bağlı sigortalı, yeşil kartlı, herhangi bir güvencesi yok), okul dışında kalmayı yordamada etkili bir değişkendir. Sağlık güvencesi azaldıkça okul dışında kalma olasılığı artmaktadır. Zorunlu ve isteğe bağlı sigortalı birine göre, yeşil kartlı olanlar ve herhangi bir güvencesi olmayanlar; yeşil kartlı birine göre de herhangi bir güvencesi olmayanlar daha fazla okul dışında kalmaktadır. Ailenin sosyal güvencesine ilişkin bilgi, ailenin aylık geliri ile ebeveynlerin kayıtlı/ kayıt dışı işlerde çalışıp çalışmadıklarına dair ipuçları sunmaktadır. Örneğin yeşil kart, herhangi bir sosyal güvencesi olmayan, sigortadan mahrum olan ve aylık geliri düşük olan ailelere verilmekte ve bu aileleri tedavi ve sağlık giderleri devlet tarafından karşılanmaktadır. Ancak ebeveynleri çalış(a)mayan ya da asgari ücretten düşük ücretli olarak kayıt dışı çalışan ailelerde ise ne yeşil kart ne de bir sağlık sigortası vardır ve bu ailedeki bireylerin tedavi ve sağlık giderleri devlet tarafından finanse edilmemektedir. Sağlık güvencesi, ailelerin yaşam koşullarına ilişkin önemli bir değişken olarak öne çıkmaktadır.

Kişibaşı yıllık gelirin okul dışında kalmayı yordama durumu yıllara göre farklılık göstermektedir. Cinsiyet ayrımına göre kişibaşı yıllık gelir değişkeni, ortaöğretim çağındaki erkek ve kız nüfusun okul dışında kalmasını yordamada 2003 ile 2016 yılı verilerine göre anlamlı bir değişken iken 2011 yılı verilerine göre anlamlı bir değişken değildir. Kişibaşı yıllık geliri yüksek olan ortaöğretim çağındaki erkek ve kızların, kişibaşı yıllık geliri düşük hemcinslerine oranla okul dışında kalma olasılıkları daha düşüktür. Kişibaşı yıllık gelir azaldıkça okul dışında kalma olasılığı artmaktadır. Gelirdeki yükseliş daha çok kadınların eğitime devamında etkilidir. Bulgular Tomul'un (2008) çalışmasındaki -gelir artışının 18-23 yaş kadınların eğitime devamında en fazla etkili olduğu- bulgularla desteklenmektedir. Aylık kişi başına düşen hanehalkı geliri ile okula kayıt arasında olumlu bir ilişki vardır. $\mathrm{Bu}$ ilişki olumlu olmakla birlikte cinsiyetlere göre farklılık göstermektedir. Gelir ile okula kayıt arasındaki bu ilişki, Tayland'taki genç erkeklerde doğrusal iken genç kızlarda ters U şeklinde olabilmektedir (Tharmmapornphilas, 2013). Gelir düşüklüğü, yoksulluğun ekonomik boyutunu belirtmektedir. Aşırı yoksulluk, okul katılımını düşüren bir etmendir, çünkü yaşamlarının bir noktasında açlıkla uğraşan çocukların okula gitme olasılıkları daha düşüktür (Cardoso ve Verner, 2006). Çocukların okul dışında kalmalarının başlıca nedeni 
yeterli para gücünün yokluğudur. Temel engelleyici etmen, öğrenimini sürdüren çocuğun getireceği gelir kaybı nedeniyle hane gelirinin düşmesidir (Dünya Bankası, 2005). Yükseköğrenim beklentisi olmayan düşük gelirli gençler, ortaöğretime devam etmek için katlanılması gereken maliyeti, bu eğitimin sağlayacağı iş bulma ve maaş kazanımının üzerinde değerlendirmekte ve kayıt dışı sektörlerde de olsa herhangi bir iş olanağ1 bulduklarında okul dışında kalabilmektedirler (Eğitim Reformu Girişimi, 2009). Ailenin ekonomik durumunun yetersizliği nedeniyle ebeveynlerin yanı sıra çocukların da işgücü piyasasına girerek para kazanmak ve aile ekonomisine katkıda bulunmak veya ev işlerindeki sorumluluklarının artması çocukların erken yaşta okul dışında kalmasına neden olmaktadır (Bakış ve diğerleri, 2009; Karadağ ve Balkar, 2015; Özdemir ve diğerleri, 2010). Gelir, okuldan kaynaklanan okul dışında kalmalarda da etkili olmaktadır. Varsıl ailelerin, çocuklarını nitelikli okullara kaydetme/aktarma olanağı varken, yoksulların böyle bir olanağı yoktur (Yolcu, 2011). Zorunlu eğitim süresinin 12 yıla çıkarılmasının yanı sıra varsıl aileler gibi yoksul ailelerin de çocuklarının eğitimini önemsemeleri okul dışında kalmayı yordamada kişibaşı y1llık gelirin etkisini düşürmüş olabilir.

Cinsiyet ayrımına göre sosyoekonomik değişkenlerin (yerleşim birimi, sağlık güvencesi, engelli olma durumu, anne ve baba eğitim düzeyi, hanehalkı büyüklüğü ve kişibaşı yıllık gelir) okul dışında kalma durumuna ilişkin çözümlemelerde anlamlı yordayıcılar olduğu, bu değişkenlerden engelli olma durumunun yordayıcı etkisi yükselirken, diğer değişkenlerin anlamlı yordayıcılar olmakla birlikte etki oranlarının yıllar itibariyle azaldığı ortaya çıkmıştır. Bu durum, zorunlu eğitim süresinin arttırılması ile ortaöğretim düzeyinde bir örgün eğitim kurumuna kayıtlı olmayanların, devamsızların ya da iki kez sınıf tekrarına düşen öğrencilerin e-okul sistemde otomatik olarak açık lise öğrencisi olarak kabul edilmesinden kaynaklandığı düşünülmektedir.

\section{Öneriler}

Araştırmada elde edilen sonuçlara dayanarak aşağıdaki politika önerileri sunulabilir.

1. Engelli çocukların farklılıklarını dikkate alacak eğitsel uygulamaların arttırılmalı, engelli çocukların ebeveynleri, engellilere yönelik kamusal desteklerden haberdar edilmeli ve çocuklarının güçlendirilmesi için yönlendirilmelidirler.

2. Var olan ekonomik sistemle yüzleşmek toplumumuzun hedefi durumuna gelmelidir. Devlet, eğitime erişimde sosyo ekonomik özelliklerin etkisini ortadan kaldıracak önlemler almalidir. 
3. Ebeveynlerin sosyal güvencelerine bakılmaksızın (güvencesiz, yeşil kartlı, zorunlu ve isteğe bağlı sigortalı), herkesin, özellikle çocukların eşit sağlık güvencesine sahip olması sağlanmalıdır.

4. Devletin ve sivil toplum kuruluşlarının burs uygulamaları ve okullaşma kampanyaları, kısmi de olsa birçok çocuğun eğitimini sürdürmesine katkı sunmaktadır. Bu yüzden yoksul ailelere, çocuğun eğitim gereksinimini karşılamaya yönelik parasal yardımlar yapılmalı ve özellikle kız çocuklarını okula göndermeyen tutucu aileleri ikna etmek için projeler geliştirilmelidir.

5. Ebeveyn eğitim düzeyinin çocukların eğitim süresi üzerindeki etkisi düşünüldüğünde tüm ülkede yetişkin okuryazarlığını arttıracak çalışmalara yer verilmeli, aile ile okul arasındaki ilişkilerin niceliği ile niteliğinin artmasına çaba gösterilmelidir.

6. Politikacılar, dini referanslara da gönderme yaparak, "her aile en az üç çocuk sahibi olmalı" ve "ailelere çocuk başına mali yardım verileceği” şeklinde söylemlerle aileleri daha fazla çocuk yapmaya özendirmemelidirler.

7. Eğitimin bir insan hakkı olması dolayısıyla, gereksinim olan yerlere gerekli okul binaları yapılmalı ve okullar arasındaki nitelik farkları kaldırılmalıdır. Haklar, maliyet yarar analizlerine feda edilmemelidir. Özellikle kırsal alanlarda ortaöğretim düzeyindeki okulların sayısı arttırılmalıdir.

8. TÜİK verilerinde bazı değişkenlerin ölçünlendirilmemesi (örneğin yerleşim birimikır ve kent), bu değişkenlere yönelik karşılaştırmaları engellemektedir. Bu yüzden TÜİK her y1l gerçekleştirdiği anketlerde temel değişkenleri ölçünlemelidir.

9. Farklı budun, inanç ve cinsel kimliklerin yaşam koşullarıyla okul dışında kalma durumlarını karşılaştırmak için TÜİK verilerinde bu değişkenlere de yer vermelidir.

10. Milli Eğitim Bakanlığı başarısızlık, devamsızlık, okuldan uzaklaştırma ve okul dışında kalmaya yönelik farklı cinsiyet, yaş, cinsel kimlik, budun, dinsel inanç, okul türü, yerleşim yeri vb. değişkenlerin yer aldığı bir veri havuzu oluşturmalıdır.

\section{Araştırma Önerileri}

$\mathrm{Bu}$ araştırmada elde edilen sonuçlardan yola çıkılarak geliştirilen ve yapılacak araştırmalara ve uygulamalara katkı sunabilecek uygulama önerileri aşağıda sıralanmaktadır.

1. Gelecek araştırmalar TÜIK'in Gelir ve Yaşam Koşulları Anketlerindeki verilere dayalı olarak gerçekleştirilebilir. 
2. $\mathrm{Bu}$ araştırma ortaöğretim düzeyindeki okul dışında kalmış çocuklarla yapılmıştır. Gelecek araştırmalar farklı eğitim düzeyindeki çocuklarla/gençlerle yapılabilir.

3. Kamuoyunda 4+4+4 diye bilinen değişiklik ile 2012-2013 öğretim yılından itibaren 12 yıllık zorunlu kademeli eğitime geçildi (İlköğretim ve eğitim kanunu ile bazı kanunlarda değişiklik yapılmasına dair kanun, 2012). Eğitim sisteminde yapılan bu kökten değişikliğin okul terklerine olan etkisi araştırılabilir.

4. Okul dışında kalma olgusu bakımından farklı ekonomik sistemlerle yönetilen ülkeler karşılaştırılabilir.

5. Kamu okulları ile özel okullardaki devamsızlık, sınıf tekrarı ve okul dışında kalma durumları karşılaştırılarak ele alınabilir.

6. Eğitim politikalarının ve okul ikliminin başarısızlık, devamsızlık, sınıf tekrarı ve okul dışında kalma oranlarını nasıl etkilediği üzerine daha çok araştırma yapılmalıdır.

7. Ülkemiz farklı ülkelerden göç almakta ve ülkemizdeki sığınmacı sayısı artmaktadır. Sığınmacıların topluma uyumunu ve eğitime devamını sağlayacak politikalara yol gösterici olmak için sığınmacıların ve sığınmacı çocuklarının toplumsal ve eğitimsel sorunlarını kapsayan alan araştırmalar planlanabilir.

Teşekkür: Hanehalkı Bütçe Anketi mikro verilerini sağlayan Devlet İstatistik Enstitüsü ile Türkiye İstatistik Kurumu çalışanlarına teşekkür ederiz.

Etik Kurul İzin Bilgisi:: Bu çalışma Ankara Üniversitesi Eğitim Bilimleri Enstitüsünün 4 Ekim 2019 tarihinde kabul ettiği, Kasım Karakütük danışmanlığında yürütülen, Selman Almış'ın doktora tezine dayanmaktadır. Bu araştırma Sinop Üniversitesi İnsan Araştırmaları Etik Kurulu'nun 12/07/2019 tarihli ve 2019-36 sayılı kararı ile alınan izinle yürütülmüştür. Araştırma amaçlarına uygun verileri elde etmek için TÜİK’ten veri isteminde bulunulmuştur. TÜİK, veri istemine olumlu yanıt vermiş, 2003-2013 yıllarına ait ilgili anketleri CD biçiminde postayla, 2016 y1lına ait anket verilerini 30.07.2018 tarihli ve 27964695-622.03-E.17240 sayılı kararla elektronik ortamda erişilebilir olarak araştırmacıya ulaştırmıştır.

Yazar Çıkar Çatışması Bilgisi: Yazarlar çıkar çatışması olmadığını beyan etmektedir.

Yazar Katkısı: Yazarlar çalışmaya eşit oranda katkı sağlamıştır 


\section{Kaynakça}

Adıgüzel, A. (2013). Kız çocuklarının okullulaşma engelleri ve çözüm önerileri (Şanlıurfa Örneği). EKEV Akademi Dergisi, 56(Yaz), 325-344.

Andrei, T., Teodorescu, D., \& Oancea, B. (2012). Quantitative Methods Used to Identify the Causes of School Dropout in EU Countries. Procedia - Social and Behavioral Sciences, 31, 188-192.

Bakış, O., Levent, H., İnsel, A. ve Polat, S. (2009). Türkiye'de eğitime erişimin belirleyicileri. İstanbul: Sabancı Üniversitesi Yayınları.

Battin-Pearson, S., Newcomb, M. D., Abbott, R. D., Hill, K. G., Catalano, R. F., \& Hawkins, J. D. (2000). Predictors of early high school dropout: a test of five theories. Journal of Educational Psychology, 92(3), 568-582. https://doi.org/10.1037/00220663.92 .3 .568

Beatty, A., Neisser, U., Trent, W. T., \& Heubert, J. P. (2001). Understanding dropouts: statistics, strategies, and high-stakes testing (A. Beatty, U. Neisser, W. T. Trent, \& J. P. Heubert, eds.). Washington, D.C.: National Research Council.

Berktold, J., Geis, S., \& Kaufman, P. (1998). Subsequent educational attainment of high school dropouts. Department of Education Office of Educational.. [Available online at: https://eric.ed.gov/?id=ED419900] Retrieved on May 2, 2017.

Birleşmiş Milletler (1949). Birleşmiş Milletler Evrensel Beyannamesi, [Çevrim içi: https://www.tbmm.gov.tr/komisyon/insanhaklari/pdf01/203-208.pdf], Erişim tarihi: 18.09.2016.

Blanden, J., \& Gregg, P. (2004). Family income and educational attainment: a review of approaches and evidence for Britain. Oxford Review of Economic Policy, 20(2), 245263. https://doi.org/10.1093/oxrep/grh014

Bora, V. (2012). Klz çocuklarının zorunlu eğitim sonrası ortaöğretime devam etmeme nedenleri. Yayınlanmamış Yüksek Lisans Tezi, Mehmet Akif Ersoy Üniversitesi, Burdur, Türkiye.

Bridgeland, J. M., Dilulio, J. J., \& Morison, K. B. (2006). The silent epidemic: Perspectives of high school dropouts. In Civic Enterprises. [Available online at: http://eric.ed.gov/?id=ED513444] Retrieved on January 26, 2016. 
Brunello, G. \& De Paola, M. (2013). The costs of early school leaving in Europe. IZA Journal of Labor Policy, 3(1), 1-31. [Available online at: http://www.izajolp.com/content/3/1/22], Retrieved on January 2, 2021.

Cardoso, A. R. ve Verner, D. (2006). School drop-out and push-out factors in Brazil: The role of early parenthood, child labor, and poverty (No: 2515). Bonn. [Available online at: https://papers.ssrn.com/sol3/papers.cfm?abstract id=975849], Retrieved on October 25, 2018.

Cemalcılar, Z., Gökşen, F. ve Çelik, Ç. (2012). İlkögrretimde okulu terke neden olan demografik, sosyal ve çevresel faktörlerin belirlenmesi çalışması. TÜBİTAK SOBAG Projesi. (Proje No : 108K222).

Crosnoe, R., Mistry, R. S., \& Elder Jr, G. H. (2002). Economic disadvantage, family dynamics, and adolescent enrollment in higher education. Journal of Marriage and Family, 64(3), 690-702. https://doi.org/10.1111/j.1741-3737.2002.00690.x

Cui, M. (2014). Exploring explanatory individual related factors of high school dropout. Unpublished master's thesis. University at Buffalo, New York, United States.

Çağlar, S. (2009). Uluslararası hukuk ve Türk hukuk sisteminde engellilerin eğitim hakkı ve devlet yükümlülükleri. Yayınlanmamış Doktora Tezi. Marmara Üniversitesi, İstanbul, Türkiye.

Çelik, Ç. (2014). Okul terk'i politikleştirmek. Eleştirel Pedagoji Dergisi, 6(34), 12-17.

Dale, R. (2010). Early school leaving. lessons from research for policy makers (NESSE Report). [Available online at: http://www.nesse.fr/nesse/activities/reports/activities/reports/early-school-leavingreport], Retrieved on December 29, 2020.

Devlet İstatistik Enstitüsü (DİE) (2003). Hanehalkı bütçe anketi fert veri seti. Ankara: Devlet İstatistik Enstitüsü.

Dilli, C. (2006). Zorunlu ĕgitim çağında bulunan kız çocuklarının okula gitmeme nedenleri (Şırnak ili örneği). Yayınlanmamış Yüksek Lisans Tezi, Fırat Üniversitesi, Elazı̆̆, Türkiye.

DİSK Araştırma Enstitüsü (2013). Çocuk işçiliği Raporu 2013 (Rapor No. 8). İstanbul: Türkiye Devrimci İşçi Sendikaları Konfederasyonu Araştırma Enstitüsü 
Dünya Bankası. (2005). Gençler için firsatları genişletmek ve yetkinlikler oluşturmak: Orta ögretim için yeni bir gündem. Washington, D.C.

Eğitim Reformu Girişimi. (2009). Eğitim İzleme Raporu 2009. İstanbul.

Eskicumalı, A. ve Önce, B. (2014). İlköğretim okullarında adrese dayalı kayıt sistemi ve eğitimde firsat eşitliği. İçinde N. S. Baykal, A. Ural ve Z. Alica (Eds.), Eleştirel Ĕ̆itim Seçkisi (pp. 289-303). Ankara: Pegem Akademi.

European Commission. (2005). Private household spending on education \& training. [Available online at: http://www.pedz.uni-mannheim.de/daten/edzb/gdbk/05/private_household_spend.pdf], Retrieved on April 29, 2019.

European Commission. (2009). Early school leaving [Available online at: https://ec.europa.eu/education/policies/school/early-school-leaving_en], Retrieved on December 30, 2020.

Genç, K. G. ve Orhan, S. (2015). Engellilere yönelik ülkemizdeki özel eğitim hizmet uygulamaları ve örnek ülke karşılaştırması. Sosyal Politika Çalışmaları Dergisi, 15(35/2), 115- 146.

Gökşen, F., Cemalcılar, Z. ve Gürlesel, C. F. (2006). Türkiye'de ilköğretim okullarında okulu terk ve izlenmesi ile önlenmesine yönelik politikalar. İstanbul: AÇEV

Gülleroğlu, H. D., Demir, S. B. ve Demirtaşl1, N. (2014). Türk öğrencilerinin PISA 20032006-2009 dönemlerindeki okuma becerilerini yordayan sosyoekonomik ve kültürel değişkenlerin araştırılması. Ankara Üniversitesi Eğitim Bilimleri Fakültesi Dergisi, 47(2), 201-222.

Gümüş, S. (2014). The effects of community factors on school participation in Turkey: A multilevel analysis. International Review of Education, 60(1), 79-98.

Hayes, R. L., Nelson, J.-L., Tabin, M., Pearson, G., \& Worthy, C. (2002). Using schoolwide data to advocate for student success. Professional School Counseling, 6(2), 8694.

Helliwell, J. F. (2001). The contribution of human and social capital to sustained economic growth. [Available online at: http://www.oecd.org/innovation/research/1825902.pdf] Retrieved on October 27, 2015. 
Hillman, D. B. (2014). Using an early warning system to identify potential high school dropouts. Unpublished doctoral dissertation, University of Northern Colorado, Colorado, United States.

Hoşgörür, V. ve Polat, M. (2015). Ortaokul öğrencilerinin okula devamsızlık nedenleri (Söke ilçesi örneği). Muğla Sıtkı Koçman Üniversitesi Ĕ̆itim Fakültesi Dergisi, 1(2), $25-42$.

Huisman, J., \& Smits, J. (2015). Keeping children in school: Effects of household and context characteristics on school dropout in 363 districts of 30 developing countries. Sage Open, 5(4), 1-16. https://doi.org/10.1177/2158244015609666

İlköğretim ve eğitim kanunu ile bazı kanunlarda değişiklik yapılmasına dair kanun $(2012,11$ Nisan). Resmi Gazete (Sayı: 28261). [Erişim adresi: https://www.resmigazete.gov.tr/eskiler/2012/04/20120411-8.htm]

Kara, Z. ve Gürhan, N. (2013). Eşit/sizliğin tarafı olmak: Mardin'de toplumsal cinsiyet alg1s1. Bilim ve Toplum, 3(5), 65-92.

Karadağ, N. ve Balkar, B. (2015). Toplumsal kalkınmanın bir aracı olarak eğitim. Trakya Üniversitesi Sosyal Bilimler Dergisi, 17(1), 225-239.

Kavak, Y. ve Ekinci, C. E. (1994). Eğitimin Finansmanı Sorunu ve Maliyetlerin Azaltılmasına İlişkin Alternatif Stratejiler. Hacettepe Üniversitesi Ĕ̈itim Fakültesi Dergisi, 10, 65-72.

Kocakurt, S. Ö. (2016). Türkiye'de kırsal alanda okullaşma ve yetişkin nüfusun eğitim durumuna ilişkin bir analiz. Yayınlanmamış Yüksek Lisans Tezi, Ankara Üniversitesi, Ankara, Türkiye.

Köse, M. R. (2006). Aile sosyoekonomik ve demografik özellikleri ile okul ve özel dershanenin liselere giriş sınavına katılan öğrencilerin akademik başarıları üzerindeki etkileri. Eğitim Bilim Toplum Dergisi, 5(17), 46-77.

Küçüker, E. (2018). Kırsal kesimde yaşayan kız çocukların örgün ortaöğretimi terk etme nedenleri. Eğitim ve Bilim, 43(195), 97-117. [Çevrim içi: https://doi.org/10.15390/EB.2018.7537], Erişim Tarihi: 30.3.2019.

Machin, S., \& Vignoles, A. (2004). Educational inequality: the widening socio-economic gap. Fiscal Studies, 25(2), 107-128. 
S.Almış ve K. Karakütük/ Pamukkale Üniversitesi Eğitim Fakültesi Dergisi, 53, 110-149, 2021

MEB (2013), Ortaöğretimde sinıf tekrarı, okul terk sebepleri ve örgün eğitim dışında kalan çocuklar politika önerileri raporu. [Çevrim içi: https://www.meb.gov.tr/earged/unicef/S\%C4\%B1n\%C4\%B1f\%20Tekrar\%C4\%B1, \%200kul\%20Terki\%20Politika\%20Raporu.pdf], Erişim Tarihi: 21.09.2017.

MEB (2014). Milli Eğitim İstatistikleri Örgün Eğitim 2013/’14. Ankara: Milli Eğitim Bakanlı̆̆ı (MEB).

Mertler, C. A. \& Reinhart, R. V. (2017). Advanced and multivariate statistical methods: Practical application and interpretation. New York: Taylor \& Francis.

Mike, I. O., Nakajjo, A., \& Isoke, D. (2016). Socioeconomic determinants of primary school drop out: the logistic model analysis. African Journal of Economic Review, 4(1), 217-241.

Moineddin, R., Matheson, F. I., \& Glazier, R. H. (2007). A simulation study of sample size for multilevel logistic regression models. BMC Medical Research Methodology, 7(1), $34-44$.

Organisation For Economic Co-Operation and Development (OECD). (2001). The wellbeing of nations: the role of human and social capital. [Available online at: http://www.oecd.org/edu/innovation-education/1870573.pdf], Retrieved on December 10, 2016.

Özbaş, M. (2012). Kız çocuklarının ortaöğretimde okullaşma oranlarına etki eden nedenlere ilişkin algıları. International Journal of New Trends in Arts, Sports \& Science Education, 1(4), 60-71. [Available online at: http://www.iojpe.org/ojs/index.php/IJTASE/article/view/156], Retrieved on April 23, 2015.

Özdamar, K. (2004). Paket programlar ve istatistiksel veri analizleri. Eskişehir: Kaan Kitabevi.

Özdemir, S., Erkan, S., Karip, E., Sezgin, F. ve Şirin, H. (2010). Illköğretim okulu ögrencilerinin okulu terk etme nedenleri ve çözüm önerileri. TÜBİTAK Projesi, (107K453).

Özel, E. ve Zelyurt, H. (2016). Anne baba eğitiminin aile çocuk ilişkilerine etkisi. Sosyal Politika Çalışmaları Dergisi, 16(36), 9-34. 
Özer, A., Gençtanırım, D. ve Ergene, T. (2011). Türk lise öğrencilerine okul terkinin yordanması: Aracı ve etkileşim değişkenleri ile bir model testi. Eğitim ve Bilim, $36(161), 302-317$.

Pehlivan, Z. (2006). Resmi genel liselerde öğrenci devamsızlı̆̆l ve buna dönük okul yönetimi politikaları (Ankara İli Örneği). Yayınlanmamış Yüksek Lisans Tezi, Ankara Üniversitesi, Ankara.

Rankin, B. H., \& Aytaç, I. A. (2006). Gender inequality in schooling: the case of Turkey. Sociology of Education, 79(1), 25-43. https://doi.org/10.1177/003804070607900102

Rosenthal, B. S. (1998). Non-school correlates of dropout: an integrative review of the literature. Children and Youth Services Review, 20(5), 413-433. [Available online at: https://doi.org/10.1016/S0190-7409(98)00015-2], Retrieved on April 2, 2016.

Rouse, C. E. (2007). Consequences for the labor market. In C. R. Belfield \& H. M. Levin (Eds.), The Price We Pay (pp. 99-124). Washington, D.C.: Brookings Institution Press.

Rumberger, R. W. (1987). High school dropouts: a review of issues and evidence. Review of Educational Research, 57(2), 101-121. [Available online at: https://doi.org/10.3102/00346543057002101], Retrieved on May 22, 2018

Rumberger, R. W. (2001). Why students drop out of school and what can be done. Dropouts in America: How severe is the problem? What do we know about intervention and prevention? 1-45. [Available online at: https://doi.org/10.1016/0047-2352(73)900160], Retrieved on July 18, 2017.

Schneider, M., Marschall, M., Teske, P., \& Roch, C. (1998). School choice and culture wars in the classroom: What different parents seek from education. Social Science Quarterly, 79(3), 489-501.

Smith, E. (2017). İkincil Veri. In J. Arthur, M. Waring, R. Coe ve L. V. Hedges (Eds.), \& I. Tekin (Trans.), Eğitimde Araştırma Yöntemleri ve Metodolojileri (pp. 205-213). Ankara: Anı Yayıncilık.

Smits, J., \& Hoşgör, A. G. (2006). Effects of family background characteristics on educational participation in Turkey. International Journal of Educational Development, 26(5), 545-560. https://doi.org/10.1016/j.ijedudev.2006.02.002 
Soydan, T. (2015). Being a teacher in the East of Turkey. Journal for Critical Education Policy Studies, 13(1), 173-209.

Şimşek, H. (2011). Lise öğrencilerinde okulu bırakma eğilimi ve nedenleri. Ĕgitim Bilimleri Araştırmaları Dergisi, 1(2), 27-47.

Şirin, H., Özdemir, S. ve Sezgin, F. (2009). Okulu terk eden çocukların ve velilerin okul terkine ilişkin görüşleri: Nitel bir inceleme. XVIII. Ulusal Eğitim Bilimleri Kurultayı, $1-3$.

Tabachnick, B. G. ve Fidell, L. S. (2015). Çok değişkenli istatistiklerin kullanımı (M. Baloğlu, Çev.). Ankara: Nobel Akademik Yayıncılık.

Tansel, A. (2002). Determinants of school attainment of boys and girls in Turkey: Individual, household and community factors. Economics of Education Review, 21(5), 455-470. [Available online at: https://doi.org/10.1016/S0272-7757(01)000280], Retrieved on March 1, 2017

Taş, A., Selvitopu, A., Bora, V. ve Demirkaya, Y. (2013). Meslek Lisesi öğrencilerinin okul terk nedenleri. Kuram ve Uygulamada Ĕ̆itim Bilimleri, 13(3), 1561-1565.

Taylı, A. (2008). Eğitim sisteminde önemli bir sorun: Okulu birakma. Türk Psikolojik Danışma ve Rehberlik Dergisi, 3(30), 89-101.

Tharmmapornphilas, R. (2013). Impact of household factors on youth's school decisions in Thailand. Economics of Education Review, 37(0), 258-272. doi:http://dx.doi.org/10.1016/j.econedurev.2013.09.007

Tilak, J. B. (2002). Determinants of household expenditure on education in rural India (Working Paper Series No. 88). New Delhi: National Council of Applied Economic Research.

Tomul, E. (2007). Türkiye'de eğitime katılım üzerinde gelirin etkisi. Pamukkale Üniversitesi Eğitim Fakültesi Dergisi, 2(22), 122-131. [Çevrim içi: http://dergipark.ulakbim.gov.tr/pauefd/article/download/5000056207/5000053416], Erişim tarihi: 14.12.2017.

Tomul, E. (2008). The relative effects of family socio-economic characteristics on participation in education in Turkey. Eurasian Journal of Educational Research, $8(30), 153-168$. 
Türkiye Büyük Millet Meclisi (1982). Türkiye Cumhuriyeti Anayasast, [Çevrim içi: https://www.tbmm.gov.tr/develop/owa/tc_anayasasi.maddeler?p3=42], $\quad$ Erişim Tarihi: 24.05.2016

Türkiye İstatistik Kurumu (TÜİK). (2009). Hanehalkı bütçe araştırması, tüketim harcamaları 2009. [Çevrim içi: http://www.tuik.gov.tr/IcerikGetir.do?istab_id=33], Erişim tarihi: 14.12.2017.

TÜİK. (2011). Hanehalkı bütçe anketi fert veri seti. Ankara: Türkiye İstatistik Kurumu. TÜİK. (2016). Hanehalkı bütçe anketi fert veri seti. Ankara: Türkiye İstatistik Kurumu.

Tunç, A. I. (2009). Kız çocuklarının okula gitmeme nedenleri (Van ili örneği). Yüzüncü Yıl Üniversitesi Ĕ̈itim Fakültesi Dergisi, VI(1), 237-269.

UNESCO (2015). Gender and EFA 2000-2015: Gender summary. [Available online at: https://unesdoc.unesco.org/ark:/48223/pf0000234809], Retrieved on May 2, 2017.

United Nations International Children's Emergency Fund (UNICEF) (2004). Çocuk haklarına dair sözleşme. [Çevrim içi: https://www.unicefturk.org/public/uploads/files/UNICEF_CocukHaklarinaDairSozle sme.pdf], Erişim tarihi: 12.10.2016.

UNICEF. (2014). The state of the World's children 2014 -Every child counts. [Çevrim içi: www.unicef.org/sowc2014/numbers], Retrieved on November 10, 2017.

UNICEF. (2017). Türkiye'de çocukların durumu analizi 2011. [Çevrim içi: http://abdigm.meb.gov.tr/projeler/ois/egitim/032.pdf], Erişim tarihi: 29.04.2019.

Uysal, A. (2008). Okulu bırakma sorunu üzerine tartışmalar: çevresel faktörler. Milli Ĕgitim, (178), 139-149.

Ünal, L. I., Özsoy, S., Yıldız, A., Güngör, S., Çankaya, D. ve Aylar, E. (2010). Ĕgitimde Toplumsal Ayrışma. Ankara: Ankara Üniversitesi Basımevi.

Vassiliou, A. (2011). Opening statement on education benchmark report. [Available online at: http://europa.eu/rapid/press-release_SPEECH-11-288_en.pdf], Retrieved on December 7, 2018.

Yolcu, H. (2011). Hanehalkının eğitim harcamalarını etkileyen etmenler: Kuramsal bir çalışma. Mehmet Akif Ersoy Üniversitesi Sosyal Bilimler Enstitüsü Dergisi, 3(5), 12- 
S.Almış ve K. Karakütük/ Pamukkale Üniversitesi Eğitim Fakültesi Dergisi, 53, 110-149, 2021

35. Çevrim içi: https://dergipark.org.tr/en/download/article-file/181764], Erişim tarihi: 02.01.2021.

Yüksel-Kaptanoğlu, İ. ve Ergöçmen, B. (2012). Çocuk gelin olmaya giden yol. Sosyoloji Araştırmaları Dergisi, 15(2), 129-161. 


\title{
Individual and Socio-economic Variables that Affecting the
} Secondary School Age Population to Stay Out of School in Turkey*

\author{
Selman ALMIŞ** Kasım KARAKÜTÜK ${ }^{* * *}$
}

• Received: 14.12.2020 • Accepted: 11.02.2021 • Online First: 11.02.2021

\begin{abstract}
This study aims to determine the individual and socio-economic variables that affect the secondary school-age population to stay out of school by gender in Turkey. Microdata sets of the household budget surveys conducted by the State Statistical Institute (SIS) in 2003 and by the Turkish Statistical Agency [TUIK] in 2011 and 2016 years are used to study of the change in the historical process of the effect of the selected variables. Since the dependent variable is binary and discrete, Binary Logistic Regression Model is used to analyze the data. In the study, the goodness of fit of the model was examined through the so-called $\mathrm{R}^{2}$ value. Cox-Snell and Nagelkerke $\mathrm{R}^{2}$ statistics were used to measure the relationship between the dependent and independent variables. It turned out that independent variables are significant predictors, and their effect levels differ by year. While the variables of disability status, health assurance, and education level of parents are effective predictors for secondary school age boys to stay out of school in the data for every three years; it turned out that settlement unit in 2011 data, household size in 2016 data and annual income per capita in 2003 and 2016 data are the effective predictors. On the other hand, as the variables of disability status, settlement unit, education level of parents, and household size are significant predictors to secondary school age girls to stay out of school in the data for every three years; it turned out that health assurance in 2003 and 2011 data, annual income per capita in 2003 and 2016 data are the effective predictors.
\end{abstract}

Key Words: Staying out of school, drop out of school, right to education, access to education, binary logistic regression

\section{Cited:}

Almış, S., \& Karakütük, K. (2021). Individual and socio-economic variables that are affecting the secondary school-age population to stay out of school in Turkey. Pamukkale University Journal of Education, 53, 110-149 doi:10.9779.pauefd.840809

\footnotetext{
* This study is based on the doctoral dissertation of the first author, prepared under the supervision of the second author.

*** Dr., Sinop University, https://orcid.org/0000-0002-1731-4204, zenselman@gmail.com, selmana@sinop.edu.tr

*** Prof. Dr., Ankara University, https://orcid.org/0000-0003-3136-1979, kkrktk@gmail.com
} 


\section{Introduction}

Education positively affects individuals' living conditions, especially by increasing their cultural, social, and economic capital, and has an important role in upward mobility in lower social classes. Education affects individual, social and financial outcomes ranging from labor market performance to health, participation in lifelong learning, job, life satisfaction, crime, social cohesion, growth, tax revenues, and social support payments (Brunello \& De Paola, 2013). Education is an effective tool that provides economic growth for societies; increase in productivity and competitiveness through the production of new knowledge and Technologies; decrease in individuals who will receive social support and increase in tax revenues in the economic dimension while combating inequalities in the society, improving the distribution of wealth, effective participation in public decisions, reduction in crime rates and development of political areas such as health conditions, social cohesion, peace and protection of the environment in the social dimension (Hayes, Nelson, Tabin, Pearson \& Worthy, 2002; Rumberger, 1987). It is recognized that education has multifaceted effects such as enhancing awareness of political and democratic society, understanding complex problems, helping technological progress, and discovering cultural talents. Education is of great importance in establishing contemporary social values such as democratization, participation, human rights, cohesion, and establishing political stability (EuropeanCommission, 2005; Helliwell, 2001; Organisation ForEconomic Co-Operation and Development (OECD), 2001; Tilak, 2002).

Education has been recognized as a basic human right for societies after the importance of education for society and individuals is understood. In the historical process, articles stating that the right to education is a "fundamental right "have been included in international agreements and national laws. In article 26 of the Universal Declaration of Human Rights and Article 28 of the Convention on The Rights of the Child, it is stated that "everyone has the right to education; Education is compulsory and free at primary and basic education level (United Nations, 1949; UNICEF, 2004). According to the 42nd article of the Constitution and the Law on Primary Education and Education No: 222, "None can be deprived of the right to education and training. Primary Education is compulsory for all male and female citizens and is free of charge in state schools (Article 2) "(Grand National Assembly of Turkey, 1982). Although it is included in the 1961 Constitution, in which everyone has the right to education. In all documents issued on education in the following 
dates, all individuals' right to education could not be implemented in practice and remains a current issue even today.

Despite the emphasis on education as a fundamental right in international and national legal regulations on education and the extension of the compulsory education progress, exclusion from school remains one of the major issues related to education in Turkey and at the international level. It is still far from achieving gender equality in education and just society based on gender. However, significant improvements have been made in access to education worldwide since the Education for All-Conference, held in 1990, which UNESCO developed in education (UNESCO, 2015). Early school leaving is seen as a major problem in Europe and the developed world. In the European Union (EU) in $2007,16.9 \%$ of the boys and $12.7 \%$ of the girls left school early (Dale, 2010), and reducing the incidence of this to $10 \%$ by 2020 is one of the basic criteria of the EU education strategy (European Commission, 2009). However, this rate was realized as 14.4\% in 2011. It is stated that this decrease is equivalent to more than a million people attending school (Vassiliou, 2011).

When the official statistics are analyzed, a significant age population has not reached the right to education for various reasons. Secondary education and higher education in Turkey have low schooling, and gender inequalities are against women (Rankin \& Aytaç, 2006; Smits \& Hoşgör, 2006; Tansel, 2002; Tomul, 2007). According to TUIK'S 2012 Child Labor Survey results, $25.30 \%$ of children in the 15-17 age group do not attend school. It is emphasized that women's participation in education is an important education problem in Turkey's east and rural areas (Smits \& Hoşgör, 2006). Although the development plans aim to ensure the access of all children to school in primary and secondary education; and reduce the grade repetition and dropout, there was an increase in the schooling rates, but the plan targets were partially realized. In Turkey, the net schooling rate in primary schools, $98.86 \%$ in 2013 , increased to $99.57 \%$ in 2014 . Likewise, in secondary schools, the net schooling rate, which was $93.09 \%$ in 2013 , increased to $94.52 \%$ in 2014 , and in secondary education, the net schooling rate increased from $70.06 \%$ to $76.65 \%$ (MEB, 2014).

In Turkey, there are still children who include in basic education and compulsory education late. The ones who never start secondary education or leave early after starting secondary education. Being out of school affects the right to education and the enjoyment of other human rights. Many studies have included the economic, psychological, and social 
effects of being out of school on those who remain out of school and its costs to society. The case of being out of school in Turkey has mostly just remained an educational problem. The education system is treated as an independent island outside of society's corporate forces (government, market, popular culture, mainstream media. etc.). Taylı (2008) emphasized that being out of school is both an individual and social problem, as it increases crime rates, anti-social behavior, and monetary losses. While being out of school causes investments in education to lose value in the individual dimension, expenditures for education are wasted, and there is a huge loss of national resources (Kavak \& Ekinci, 1994; Uysal, 2008).

The socio-economic consequences of being out-of-school are severe; likewise, the individual consequences are also quite severe. The vast majority of children who are out of school face child labor, a human rights problem, that is, the most brutal form of labor exploitation. (United Nations International Children's Emergency Fund (UNICEF), 2014). Children are increasingly undertaking domestic services (child and elderly care, cleaning, cooking, etc.) (DİSK Research Institute, 2013). According to TUIK's 2012 Child Labor Survey Results: $15.60 \%$ of the children in the $15-17$ age group work, and $34.30 \%$ of these working children attend a school. Worldwide $11 \%$ of girls are forced into marriage before the age of 15, endangering their health, education, and protection rights (UNICEF, 2014). In reducing the likelihood of girls being forced brides throughout Turkey, girls' education levels are the most decisive factor.

Reduced education times for girls increase the likelihood of getting married early. In Turkey, women who have never enrolled in school or graduated from primary school are 10.2 times more likely to be married early than women who have at least graduated from secondary school. The probability of a child being a forced bride is 5.9 times for those who finish primary school and 4.9 times for those who finish secondary school (YükselKaptanoğlu \& Ergöçmen, 2012). Those who are out of school earn less than those who finish school with a diploma. As the difference between education levels increases, earnings decrease.

Similarly, out of school are more likely to be unemployed or remain out of the labor force as frustrated workers. They work about two months less per year than those with high school degrees as their highest education level and work about three months less per year than those with a post-high school degree (Rouse. 2007). According to a report conducted by Bridgeland, Dilulio, and Morison (2006), high school dropouts earn an average of 9200 
dollars less per year than graduates while earning about 1 million dollars less during their lifetime to university graduates. Again in the unemployment rate in 2004, high school dropouts' unemployment rate is more than three times higher than that of university graduates. Their impoverishment from one year to the next is twice as much as those who graduated from high school.

In terms of the education system, dropout rates are among the quality indicators of the education/school; low dropout rates affirm the quality of the education system, while high dropout rates are considered negative regarding education quality. The rate of loss, regarding the quantity dimension of productivity in education, which is especially used in calculating the internal efficiency of education/school, consists of school dropouts and grade repetitions. As the loss (dropout) rate increases, the internal efficiency of education/school falls.

Early school leaving results from many factors such as poor school experience, lack of ability, low perceived returns to education from the labor market, large reductions in future benefits, poor social environment, and peer influence (Brunello \& De Paola, 2013). As a result, children who are out of school may face many negativities individually. Some of them are: children's cognitive, social, psychological, and physical development is negatively affected, and therefore children face neglect and violation of their right to life such as education, healthy development, and socialization. In the future, they are more likely to face unemployment, lower-income, not being aware of social rights, and hence less benefiting from social rights.

When the study results were examined, it was determined that the sources affecting both "participation in education" and "school dropout" were similar. In general, it can be said that school dropout is related to cultural, structural, and resource dimensions at the individual, family, community, and country level. Rosenthal collected the out-of-school variables associated with dropout as -125 specific variables in 12 sets by evaluating the findings of 37 studies on dropout (1998). These are socio-economic status, minority group status, gender, social characteristics, household stress, taking adult roles, social support for staying in school, family processes, student participation in education, the need for autonomy against social cohesion, social deviance, and personality traits. Studies have shown that inequalities in access to education are caused by the country's socio-economic structure and priorities at the macro level and familial and individual factors at the micro- 
level (Tomul, 2007). Berktold, Geis, and Kaufman, in their longitudinal study (1998) on eighth-grade students' dropout, stated that $77 \%$ of school dropouts were related to school, $34 \%$ to the family; and $32 \%$ to the job. According to Gümüş's findings (2014), social context effects such as adult education level and women's empowerment in society and well-known household factors such as parental education, household wealth, and household size are very important in terms of children's school participation.

Most of the change in dropout $(72 \%)$ is due to household level factors. Socioeconomic resources (parental education, father's occupation, and wealth) are the most important factors. The family's social, cultural, and economic structure plays an important role in dropping out or attending school (Huisman \& Smits, 2015). Familial factors such as where the family lives (rural/ urban), parents' education, parents' occupation, household size, birth order, and family income are effective in children's education period. It is emphasized that especially the education level of parents and the income per capita are important factors on the education period of the child and are highly correlated with other socio-economic factors (Blanden \& Gregg, 2004; Crosnoe, Mistry \& Elder Jr, 2002; Machin \& Vignoles, 2004; Smits \& Hoşgör 2006; Tomul, 2007). Social context factors such as the level of adult education and women's empowerment in society and well-known householdlevel factors such as parental education, household wealth, and household size are very important for children's school participation (Gümüş 2014). The literature states that demographic variables such as gender, race and ethnic origin, immigration status, and speaking a mother tongue different from the language of education are significantly associated with school dropout (Rumberger, 2001).

Some of the studies conducted in Turkey on staying out of school aimed to identify students at risk of leaving school in advance and take precautions accordingly (MEB, 2013). According to their study, the reasons for school dropout were explained as family-related reasons (socio-economic structure of the family, family pressure/indifference), decreased trust in the school, the effect of friends and social environment, school failure (academic failure, grade repetition, absenteeism) and early marriages. In Tomul's study (2007), it has been found that children in families with high-income levels have high participation in education; the participation of both sexes in education differs according to region and income; women's participation in education at all income levels and regions is lower than Men's; and the effect of the increase in income on participation in education differs by gender and regions. 
Özer, Gençtanırım, and Ergene (2011) stated that taking disciplinary punishment, alcohol, smoking and anti-social behavior increases the risk of dropping out of school; on the other hand, they state that social support, especially teacher support, reduces the risk of dropping out of school. Taş, Selvitopu, Bora, and Demirkaya (2013) noted that the attitudes and behaviors of peers affect the dropout risk; while Şimşek (2011) stated that, in addition to personal characteristics, factors such as family structure (multi-child family), education system, satisfaction with school and teacher affect the likelihood of dropping out.

In the context of exclusion from school studies, that especially focus on barriers related to girls' schooling, were conducted. Bora (2012) states that the family's economic situation, social roles assigned to girls, coeducation, and clothing practices in schools are effective in preventing parents from sending girls to secondary education. Adigüzel (2013) stated that the main reason why girls are excluded from school is socio-economic and cultural factors. According to the study results of Şirin, Özdemir, and Sezgin (2009), boys are excluded from school for reasons of contributing to family income, and girls are excluded from school for reasons of taking care of siblings at home to support working mothers

According to Husman and Smits (2015), one of the important factors in school dropout is related to educational resources (availability of schools and teachers). Tayl (2008) emphasizes that students' relationships with teachers and friends, reasons for school and family, personal and social reasons play an important role in dropping out of school. Uysal (2008) stated that the most important environmental factor affecting school dropout is the school environment. School disruptions, especially the school's quality, size, atmosphere, and teachers' attitudes affect children's staying in the educational system. In the longitudinal study conducted by Berktold et al. (1998), it was stated that the most obvious reasons for school dropout were "dislike school (46\%), "school failure (39\%), "bad relations with teachers (29\%)" and "finding a job and working (27\%)".

Andrei, Teodorescu, and Oance (2012) conducted a study on school dropout using data sets recorded in 27 EU countries during 2000-2009. In this study, they noted the following details: The increase in the share of education expenditures in GSYİH causes the quality of education to increase, and thus it decreases dropout rates; as the number of students per teacher decrease, dropout decreases significantly; and lastly the higher the unemployment rate in the labor market the higher the school dropout rates. In this study, it is 
also stated a certain level of school dropout in EU countries is determined by cultural factors, migration to the continent, economic and social factors.

Huisman and Smits (2015) state in their study that the development level of the region also plays an important role in dropping out of school. The fact that public facilities are not distributed equally to the settlements causes the quality of education and training services to differ depending on the location of the cities in the country geography and the location of the housing in the city geography (Eskicumalı \& Önce, 2014). In the phenomenon of being out of school, the characteristics of the place where children live have not been taken into account adequately. The concentration of the urban population in certain urban places depending on their social position (ethnic, class, origins, cultural and religious affiliations, etc.) and their physical separation from each other and therefore a limited cultural interaction causes a socio-spatial division of educational institutions (Ünal, Özsoy, Yıldız, Güngör, Çankaya \& Aylar, 2010). On the other hand, Çelik (2014) states that even though they live in the same disadvantaged neighborhoods, students who attend school differ from school dropouts in socio-economic and economic terms.

Although Turkey has been among the 25 countries participating in the Global Initiative for Children Out of School, UNICEF and UNESCO Institute of Statistics conducts that since 2010, the Ministry of Education (MEB) has not conducted a comprehensive study of children who were out of school until 2013. MEB also carried out this study in 2013 in cooperation with UNICEF (MEB 2013). Therefore, the problem is still up to date. Although socio-economic factors, which are especially the reasons for being out of school, have been emphasized in many studies, the causes of socio-economic disparities and the practices of the education system that create inequality have not been problematic in these studies. What's more, the naturalness of these inequalities has been adopted.

According to Tomul (2007), education includes the possibility of alleviating social and economic inequalities and increasing the possibility of reproducing existing inequalities with inaccuracies in its purpose, structure, and processes. Schooling rates, which reflect access to education, make inequalities in education more visible. Secondary education is one of Turkey's educational levels where the targeted level of participation is not achieved. As the targeted schooling rates in secondary schools are not achieved, the school diversity and educational quality are also at the center of important political debates. Secondary education is an important stage in the education system in terms of access to education. According to 
Köse (2006), the decision on which type of secondary education students will attend in the next stage after primary education is important in determining students' future living conditions. Huisman and Smits (2015) emphasize that the transition from primary school to secondary education is an important breaking point in children's educational careers in developing countries. Students considering leaving school mostly implement these decisions during their high school years (Battin-Pearson, Newcomb, Abbott, Hill, Catalano \& Hawkins, 2000).

When the national and international literature is examined, it is thought that determining the factors affecting students' exclusion from school as a whole by multilinked analyzes will be important in terms of determining the variables that can be intervened to improve results and providing data for policies and practices to be formed. Studies of the reasons for participation or leaving school at the international and national level have shown that education level may change depending on the social policies applied in countries, the development of countries, and time. It is believed that determining the social and economic reasons affecting school dropouts at the secondary level in Turkey can contribute to macro/micro policies created to increase education access in the future. For this reason, it is thought that it will be important to determine the individual and socio-economic variables that affect the exclusion of the secondary education age population from school in Turkey.

This study aims to determine the change in the historical process of individual and socio-economic variables affecting the exclusion of secondary education age population from school by gender in Turkey.

\section{Method}

The study aims to determine individual and socio-economical variables that affect the exclusion of the secondary age population from school in Turkey according to selected years. The research is in the relational scanning model.

\section{Data Sources}

The study's statistical data were obtained from the DİE 2003 Household Budget Survey and the individual and household microdata sets in TUIK'S 2011 and 2016 Household Budget Surveys. Household Budget Surveys include information on socio-economic structures, levels of life, and spending patterns of households, and these surveys are one of the most important sources used to determine the needs of the public, to know how the available 
income is distributed among households or individuals and to test the validity of the applied socio-economic policies (TUIK, 2009). For this reason, the data used in the research is secondary data (Smith, 2017). In order to obtain data suitable for research purposes from the data in the surveys mentioned above, data was requested from TUIK. TUIK responded positively to the data request and delivered the relevant surveys for 2003-2013 by mail in the CD form. The survey data for 2016 has been made available as accessible in an electronic environment to the researcher (Appendix-1).

The 2003 Household Budget Survey (DİE, 2003) was prepared to provide income distribution information in 2002. During the 12 months of 2003, it was applied to 107614 people from 25920 households (1512 in the city and 648 in a rural area). Using a survey, Social and economic data have been obtained to separate urban and rural places throughout Turkey. Information from households was compiled using interview, recording, and observation methods.

The scope of the 2011 Household Budget Survey (TUIK, 2011) is individuals living in households located within the borders of the Republic of Turkey. In the study, people included in the corporate population and the nomadic people were excluded. The survey's sampling structure was created to estimate based on "Turkey, City, Rural." The survey was applied to 13248 households for one year by taking 1104 sample households, which changed every month between January 1 and December 31. Using the survey, Social and economic data have been obtained to separate urban and rural places throughout Turkey. Information from households was compiled using interview, recording, and observation methods.

The scope of the 2016 Household Budget Survey (TUIK, 2016) is individuals living in households located within the Republic of Turkey's borders. This survey was applied to 15552 households for one year by taking 1296 sample households that changed every month between January 1 and December 31. However, the data collected from 12096 households was adequate for the purpose. The 2016 Household Budget Survey was conducted by alternately monitoring an average of 1296 different sample households each month. A total of 15552 households was surveyed throughout the year, and the number of households whose survey was valid was 12096. Information from households was compiled using interview, recording, and observation methods.

In the 13-17 years, age group selected from micro-data in the household labor force surveys conducted by DİE in 2003 and TUIK in 2011 and 2016 were used as sampling. In 
determining the years of datasets, it is aimed to see the trend of change of factors affecting exclusion from school by comparing before and after the 2008 economic crisis. For this purpose, the year 2016 was selected for the most up-to-date data; the year 2011 was selected to determine the effects of the post-crisis, and the year 2003 data was chosen as it is the most comprehensive study in terms of variables. Sampling size contained so far to reveal the precrisis situation. The study's scope is the children of the secondary education age in the age group of 13-17 years old in Turkey in 2003, 2011, and 2016. In the 2003 and 2011 Household Budget Survey, the age variable in the individual data set was covered by the 1317 years age group because it was specified as the finished age; in the 2016 data's set, the age variable was covered by the 14-18 years age group because it indicated the current age. From this point of view, the concept of the secondary education age population in this study covers the current population of 14-18 years old.

\section{Process}

The dependent variable of this study is not the student /the student variable. The independent variables are the settlement unit (rural/urban) where the population of 13-17 years age lives, Health Assurance, Disability Status (yes/ no), Father's education level, Mother's education level, Annual income per capita, and Household Size. The dependent variable is taken from the data on whether an individual is enrolled in any educational institution. In the 2003 and 2011 Household Budget Survey, the individual data set was edited to take into account whether the population in the 13-17 years age range is a student or not. Age-related values indicate finished age. In other words, the 13 years-old group indicates getting days from the age of 14 by finishing 13 years of age. In the individual data set of the 2016 Household Budget Survey, the data was arranged by considering the student status (student (1) /not student (0)) of the population in the 14-18 years age range. Non-students denote those who are not enrolled in any level of education. In Binary Logistics Regression analysis, the student is encoded as " 0 , "Likewise, non-student is encoded as " 1 "as this study is intended to determine the variables that predict staying out of school.

In the individual data set of 2003, 2011, and 2016 Household Budget Survey, 13-17 years age population, mother and father were determined according to the article proximity to the household head. In this article coding in the 2003 and 2011 data sets, the head of the household is encoded as " 0 "; the wife as " 1 "; and son/daughter as " 2 ". In the individual's gender part, the male (boy) is encoded as "1," and the girl is encoded as " 2 ". In the head of 
the household variable, those encoded as " 0 " and specified as male are considered to be "father"; in the head of the household variable, those encoded as " 1 " and specified as female /woman are considered to be "mother" and in the head of the household variable those encoded as "2" and specified as in the range of 13-17 years age are accepted as son/daughter.

In TUIK's 2016 data set, this item is stated by coding the household manager as "1"; the wife as " 2 "; and son/daughter as " 3 ". In the gender section, the male is encoded as " 1 ," and the woman is encoded as " 2 ". In the household manager variable, those with a " 1 " code and whose gender is specified as male are accepted as "father"; in the household manager variable, those with a " 2 "code and whose gender is specified as a woman are accepted as "mother", and in the household manager variable those coded with a " 2 " and specified as "in the 13-17 years age" are accepted as son/daughter. Those with "the same bulletin" codes in the data set indicate the same family structure.

The gender of the population of 13-17 years age (male/female), residential area/settlement unit (rural /urban) of the 13-17 years age population, Health Assurance, Disability Status (yes/no), Father's education level, Mother's education level, Annual income per capita and Household Size were taken as independent variables.

The gender was coded as male "1" and girl as "2"; and in Binary Logistics Analysis, the male was taken as the reference value.

The settlement where she/he lives were taken according to the rural-urban distinction. TUIK $(2003,2011)$ defined the settlements with a population of 20000 or less as Rural " 1 "and the settlements with a population of 20001 and more as "cities" (2). The city is taken as a reference value in Binary Logistics Analysis. In the individual and household data set of the 2016 Household Budget Survey, there is no rural/urban distinction.

Health Assurance variable was made according to the data of whether there is health insurance or not. This variable is classified as "compulsory and optional insured," "with green card," and "no assurance." The compulsory and optional insured is encoded as " 1 "; Green Card variable is encoded as " 2 ," and no assurance is encoded as " 3 ". In Binary logistics Analysis "compulsory and optional insured" variable was taken as the reference value.

Disability Status (yes/no) variable is included in the 2011 and 2016 Household Budget Survey's data set as "whether there is a physical or cognitive problem that prevents 
daily activity." There is no item related to this variable in the 2003 Household Budget Survey's data set. Having a disability was encoded as "1" and "not having a disability" was encoded as “2”. In Binary Logistics Analysis "not having disability” variable was taken as the reference value.

Father and mother education levels were reclassified and coded as given in Table 2 based on the individual data set of the Household Budget Surveys in 2003, 2011, and 2016. In Binary Logistics Analysis "higher education graduate" variable was taken as the reference value.

The transformations regarding the reclassification and coding of the mother and father education level variable based on the individual data set of the Household Budget Surveys in 2003, 2011, and 2016 are given in Table 1.

Table 1: The reconstructed categories and codes of father and mother education level

Code and Definition in the Household Data Set Categories and Codes in the Research of 2003, 2011, and 2016 Household Budget Data Set

Survey

\begin{tabular}{ll}
\hline $\begin{array}{l}\text { 1. illiterate } \\
\text { 2. was literate but did not graduate from }\end{array}$ & $\begin{array}{l}\text { 1. not graduated (1. Illiterate }+2 . \text { Was } \\
\text { literate but did not graduate from a } \\
\text { school) }\end{array}$ \\
\hline 3. primary school & $\begin{array}{l}\text { 2. primary school graduate (3. Primary } \\
\text { school) }\end{array}$ \\
\hline 4. primary education & $\begin{array}{l}\text { 3. primary school graduate (4. primary } \\
\text { 5. secondary school }\end{array}$ \\
6. middle equivalent profession & equivalent profession) \\
\hline 7. high school & $\begin{array}{l}\text { 4. high school or equivalent school } \\
\text { 8. high school equivalent profession } \\
\text { graduate (7. High school +8. High school } \\
\text { equivalent profession }\end{array}$ \\
\hline 9. junior college & $\begin{array}{l}\text { 5. higher education graduate }(9 . \text { Junior } \\
\text { 10. four-year college, faculty } \\
\text { 11. master, doctorate }\end{array}$ \\
\hline
\end{tabular}

When Table 1 is examined, it is seen that combinations and renames are made on the codes and definitions in the household data set of the Household Budget Survey. In other words, Table 1 combines and renames the codes and definitions in the household data set of 
the Household Budget Survey. For example, the 1st and 2 nd codes belonging to "illiterate "and "literate but did not graduate from a school "variables in the data set were combined as "Code 1 -not graduated "in the Research Data Set.

As the size of the household, the total number of people living in the household was taken. The household's size was recorded by grouping the raw data in the household data set of 2003, 2011, and 2016 Household Budget Survey. Accordingly, if the household size is 3 or less as "1"; four persons as "2"; five persons as "3"; six persons as "4"; seven and eight persons as "5" and nine or more persons were encoded as "6". In Binary Logistics Analysis household size "3 or less" variable was taken as the reference value.

The income variable was determined based on "annual available household income" data in the household data set of 2003, 2011, and 2016 Household Budget Surveys. In the first stage, income per capita was calculated by dividing the household size value's annual available household income. In the second stage, income per capita was ranked in descending order, and the values corresponding to $20 \%$ of the population were determined and named. Annual available income per capita range and group definitions were given in Table 2 according to $20 \%$ population segments.

Table 1. Annual Available Income Per Capita Range and Group Definitions According To $20 \%$ Populations Segments

\begin{tabular}{|c|c|c|c|c|}
\hline Population & Group & Income Per Capita & Range By Years & \\
\hline Groups & Definition & 2003 Years (TL) & 2011 Years (YTL) & 2016 Years (YTL) \\
\hline I.\%20 & $\begin{array}{l}\text { Lower- } \\
\text { income }\end{array}$ & $\begin{array}{l}750984285,7 \text { and } \\
\text { below }\end{array}$ & 2122,27 and below & 3759 and below \\
\hline II. $\% 20$ & $\begin{array}{l}\text { Lower } \\
\text { middle } \\
\text { income }\end{array}$ & $\begin{array}{l}\text { 750984286- } \\
1189774000 \\
\text { between }\end{array}$ & $\begin{array}{l}2122,28-3449,75 \\
\text { between }\end{array}$ & 3760-5909 between \\
\hline III.\%20 & $\begin{array}{l}\text { Middle } \\
\text { income }\end{array}$ & $\begin{array}{l}1189774001- \\
1729105363 \\
\text { between }\end{array}$ & $\begin{array}{l}3449,76-5157,5 \\
\text { between }\end{array}$ & $5910-8376$ between \\
\hline IV.\%20 & $\begin{array}{l}\text { Upper- } \\
\text { middle } \\
\text { income }\end{array}$ & $\begin{array}{l}1729105364- \\
2647500000 \\
\text { between }\end{array}$ & $\begin{array}{l}\text { 5157,51-7683,36 } \\
\text { between }\end{array}$ & $8377-12438$ between \\
\hline VI.\%20 & Upper & 2647500001 & 7683,37 and above & 12439 and above \\
\hline
\end{tabular}




\begin{tabular}{lllll}
\hline $\begin{array}{l}\text { Population } \\
\text { Groups }\end{array}$ & Group & Income Per Capita Range By Years \\
& Definition & 2003 Years (TL) & 2011 Years (YTL) & 2016 Years (YTL) \\
\hline & income & above & \\
\hline
\end{tabular}

As seen in Table 2, the lower-income group as "1"; the lower-middle-income group as "2"; the middle-income group as " 3 "; the upper-middle-income group as " 4 " and the upper-income group were encoded as " 5 " in the data set. In Binary Logistics Analysis, the "upper-income group" was taken as the reference value.

\section{Analysis of the Data}

Logistics regression analysis was used to determine the variables affecting the probability of being excluded from school and their effects. Logistics regression aims to predict the values in a dependent variable consisting of two or more categories. Independent variables can be categorical and numeric. Since the dependent variable consists of only two categories, logistics regression predicts the dependent variable's probability occurring as the values of the independent variable change (Mertler \& Reinhart, 2017, p. 18). Logistics regression is preferred because it does not require any assumptions about the distribution of the predicted dependent variable (such as the normal distribution of independent predictor variables, linearity, and equality of variance-covariance matrices) and being continuous, discontinuous, or binary mixing of predictors (Tabachnick \& Fidell, 2015, p. 439).

Although logistics regression can predict the values in a dependent variable consisting of two or more categories, Binary Logistics Regression was used in this study because it is binary and discrete. Binary Logistics Regression coefficient $(\operatorname{Exp}(B))$ offers the opportunity to analyze the effect of predictor variables on the dependent variable (Özdamar, 2004). Independent variables (Gender, Annual Available Income Per Capita, Settlement Unit, Household Size, Education Level of mother and father, Health Assurance, Disability Status) are categorical. Because of these features, Binary Logistics Regression was applied to analyze the predictive variables' effect on the predicted variable.

There are some important imperatives for choosing logistics regression. For example, suppose the number and ratio of individuals in the categories of predictor variables are too low. In that case, the analysis can produce standard errors with sufficiently large parameter estimates, and the reliability of the model is reduced. The study took into account that each predictor variable had categories of at least 50 units (Moineddin, Matheson \& Glazier, 2007). When this goal was not achieved, it was preferred to exclude the relevant variable 
from the analysis instead of the category combination. The high correlation between the independent variables under logistics regression reveals the multiple connection problem. In this case, some variables should be removed from the analysis. Again, extreme values with standardized residuals or errors (Zresid value greater than 2.5) between the observed data and the model's predicted values were removed from the analysis.

The model includes eight independent variables (Gender, Annual Available Income Per Capita, Settlement Unit, Household Size, Education Level of mother and father, Health Assurance, Disability Status). Logistics regression was applied with a two-stage model in the study. First, the model was determined to determine the significance of independent variables' effect on the dependent variable. The predictive effect of the independent variables was evaluated by looking at $\mathrm{p}<0.05$ significance level. In the second stage of the model, the coefficients (Exp (B)) expressing the relative effect of the predictor variables' subcategories on the predicted variable were determined.

In line with the study's aims, while determining the effect of socio-economic variables to stay out of school both collectively and by gender and location, firstly, the values related to whether the model met the assumptions or not were examined. Preliminary analyzes showing model fit values were given in order by years for the purposes of the research.

The results of the analysis of the model fit of the Binary Logistics Regression performed to determine whether socio-economic variables by gender affect the exclusion from school:

According to the data of DİE 2003 and TUIK 2011 and 2016, the results of the model fit analysis regarding the effect of socio-economic variables by gender on exclusion from school are given below.

Model Fit Analysis Results of 2003 Data: In the model, the correlation values between independent variables are between -0.619 and +0.369 in boys and -596 and +0.320 in girls. So the model does not have a multiple linear connection problem. The model includes six independent variables (Settlement Unit, Social Security, Annual Available Income Per Capita, Household Size, Education Level of father and mother). The complete model including all the predictors was found to be statistically significant (for boys: $\beta=$ 1.022; Wald $=1195.903 ; p=0.000 ; \operatorname{Exp}(B)=0.363$; for girls: $\beta=-0.363$; Wald $=200.272 ; p=$ $0.000 ; \operatorname{Exp}(B)=0.696)$. Model values show that the model can distinguish between students 
and non-students according to the distinction between boys and girls. As a whole, the model can explain a part between $8.5 \%\left(\right.$ Cox and Snell $\mathrm{R}^{2}$ ) and $12.4 \%\left(\right.$ Nagelkerke $\mathrm{R}^{2}$ ) of the variance related to the non-student of the male population of secondary school age and can accurately classify $74.0 \%$ of the participants. It can explain a part between $15.0 \%$ (Cox and Snell $\mathrm{R}^{2}$ ) and $21.2 \%$ (Nagelkerke $\mathrm{R}^{2}$ ) of the variance related to the non-student of the female population of secondary school age. It can accurately classify $69.1 \%$ of the participants. The Hosmer and Lemeshow test results are significant (male: $p=0.097$; girl: $p=0.057$ ) when predictive variables are included in the analysis. The fact that the significance level obtained is higher than 0.05 indicates that there is no problem with the adequate model-data fit.

Model Fit Analysis Results of 2011 Data: In the model, the correlation values between independent variables are between -0.267 and +0.376 in boys and -292 and +0.382 in girls. So the model does not have a multiple linear connection problem. The model includes six independent variables (Settlement Unit, Social Security, Annual Available Income Per Capita, Household Size, Education Level of father and mother). The complete model including all the predictors was found to be statistically significant (for boys: $\beta=$ 1.488; Wald = 581.681; $\mathrm{p}=0.000 ; \operatorname{Exp}(\mathrm{B})=4.42$; for girls: $\beta=-1.161 ; \mathrm{Wald}=415.581 ; \mathrm{p}=$ 0.000; $\operatorname{Exp}(\mathrm{B})=3.19)$. Model values show that the model can distinguish between students and non-students according to the distinction between boys and girls. As a whole, the model can explain a part between $9.7 \%\left(\right.$ Cox and Snell $\mathrm{R}^{2}$ ) and $15.8 \%$ (Nagelkerke $\mathrm{R}^{2}$ ) of the variance related to the non-student of the male population of secondary school age and can accurately classify $81.6 \%$ of the participants. It can explain a part between $19.4 \%$ (Cox and Snell $\mathrm{R}^{2}$ ) and $29.1 \%$ (Nagelkerke $\mathrm{R}^{2}$ ) of the non-student female secondary school-age population variance. It can accurately classify $79.4 \%$ of the participants. The Hosmer and Lemeshow test results are significant when predictive variables are included in the analysis (male: $\mathrm{p}=0.892$; girl: $\mathrm{p}=0.526$ ). The fact that the significance level is high indicates that there is no problem with the adequate model-data fit.

Model Fit Analysis Results of 2016 Data: In the model, the correlation values between independent variables are between -0.82 and +0.414 in boys and -213 and +0.412 in girls. So the model does not have a multiple linear connection problem. The model includes six independent variables (Settlement Unit, Social Security, Annual Available Income Per Capita, Household Size, Education Level of father and mother). The complete model including all the predictors was found to be statistically significant (for boys $\beta=$ 1.509; Wald $=836.972 ; p=0.000 ; \operatorname{Exp}(B)=0.221$; for girls: $\beta=1.337$; Wald $=658.617 ; p=$ 
$0.000 \operatorname{Exp}(B)=0.263)$. Model values show that the model can distinguish between students and non-students according to the distinction between boys and girls. As a whole, the model can explain a part between $4.9 \%\left(\mathrm{Cox}\right.$ and Snell $\mathrm{R}^{2}$ ) and $8.1 \%\left(\right.$ Nagelkerke $\mathrm{R}^{2}$ ) of the variance related to the non-student of the male population of secondary school age and can accurately classify $82.1 \%$ of the participants. It can explain a part between $5.8 \%$ (Cox and Snell $\mathrm{R}^{2}$ ) and $9 \%$ (Nagelkerke $\mathrm{R}^{2}$ ) of the non-student female secondary school-age population variance. It can accurately classify $79.7 \%$ of the participants. The Hosmer and Lemeshow test results are significant when predictive variables are included in the analysis (male: $\mathrm{p}=0.184$; girl: $\mathrm{p}=0.107$ ). The fact that the significance level is high indicates that there is no problem with the adequate model-data fit.

\section{Conclusions}

The numbers and rates of being a student /not being a student of the population of secondary school age according to gender by years $(2003,2011$, and 2016) are given in Table 3 and Figure 3 for visual comparison.

When Table 3 is examined, it is seen that $25.2 \%$ of the secondary school-age population in $2003,21 \%$ in 2011 , and $22.2 \%$ in 2016 were out of school. It is also seen that $63 \%$ of those who were out of school in $2003,54.7 \%$ in 2011, and 50.6\% in 2016 were girls. Out-of-school rates of boys and girls at secondary school age are given in Figure 1.

Table 2. The distribution of the student status of the population aged 13-17 years by gender by years.

Years Gender Not student Student Total




\begin{tabular}{|c|c|c|c|c|c|c|c|c|}
\hline & & $\mathbf{f}$ & $\%$ & f & $\%$ & f & $\%$ & Not being student $\%$ \\
\hline \multirow{3}{*}{2003} & Male & 1031 & 37.05 & 4443 & 53.89 & 5474 & 49.64 & 18.83 \\
\hline & Girl & 1752 & 62.95 & 3802 & 46.11 & 5554 & 50.36 & 31.54 \\
\hline & Total & 2783 & 25.24 & 8245 & 74.76 & 11028 & 100.00 & 25.24 \\
\hline \multirow{3}{*}{2011} & Male & 343 & 45.31 & 1490 & 52.39 & 1833 & 50.90 & 18.71 \\
\hline & Girl & 414 & 54.69 & 1354 & 47.61 & 1768 & 49.10 & 23.42 \\
\hline & Total & 757 & 21.02 & 2844 & 78.98 & 3601 & 100.00 & 21.02 \\
\hline \multirow{3}{*}{2016} & Male & 448 & 49.45 & 1695 & 53.40 & 2143 & 52.52 & 20.91 \\
\hline & Girl & 458 & 50.55 & 1479 & 46.60 & 1937 & 49.10 & 23.64 \\
\hline & Total & 906 & 22.21 & 3174 & 77.79 & 4080 & 100.00 & 22.21 \\
\hline
\end{tabular}

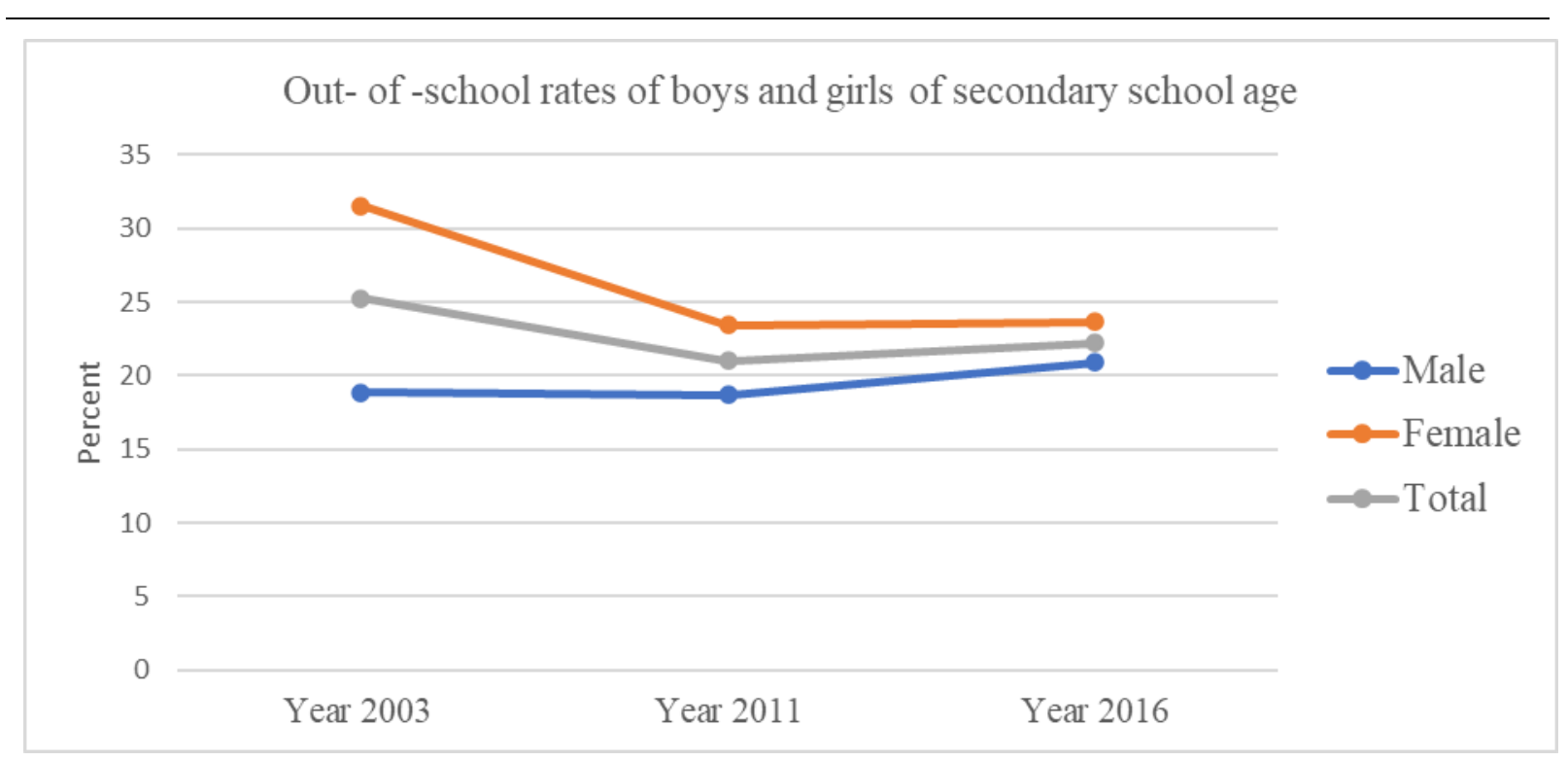

Figure 1: Out-of-School rates of boys and girls by years

When Figure 1 is analyzed, it is seen that the difference between the out-of-school rates between the genders (boys and girls) especially decreases. It is also seen that the rate of exclusion of boys and girls at secondary school age decreased towards 2011 and showed a slight increase after 2011. 
The results of Binary Logistics Regression Analysis were made to determine the effect of socio-economic variables on staying out of school according to gender (girl/ boy) are given in Table 4.

Table 4: According to the data of analysis results of 2003, 2011, and 2016, the effect of socio-economic variables on the exclusion of boys and girls from schools.

\begin{tabular}{|c|c|c|c|c|c|c|c|c|c|}
\hline \multirow{2}{*}{$\begin{array}{l}\text { Independent } \\
\text { variables }\end{array}$} & \multirow{2}{*}{ Year } & \multicolumn{4}{|l|}{ Male } & \multicolumn{4}{|l|}{ Girl } \\
\hline & & $\boldsymbol{\beta}$ & Wald & $p$ & $\operatorname{Exp}(B)$ & $\boldsymbol{\beta}$ & Wald & $P$ & $\operatorname{Exp}(B)$ \\
\hline \multirow{3}{*}{ Settlement Unit } & 2003 & 0.23 & 24.47 & $0.00 *$ & 1.26 & 0.29 & 50.07 & $0.00 *$ & 1.33 \\
\hline & & & & & & & & & \\
\hline & 2011 & 0.10 & 0.48 & 0.49 & 1.10 & 0.42 & 9.83 & $0.00 *$ & 1.52 \\
\hline \multirow{3}{*}{$\begin{array}{l}\text { Health } \\
\text { Assurance }\end{array}$} & 2003 & 0.50 & 37.91 & $0.00 *$ & 1.65 & 0.53 & 54.12 & $0.00 *$ & 1.71 \\
\hline & 2011 & 0.36 & 13.21 & $0.00 *$ & 1.44 & 0.34 & 12.28 & $0.00 *$ & 1.41 \\
\hline & 2016 & 0.04 & 5.19 & $0.02 *$ & 1.03 & 0.02 & 1.18 & 0.28 & 1.02 \\
\hline Education & 2003 & 0.47 & 68.33 & $0.00 *$ & 1.60 & 0.31 & 43.83 & $0.00 *$ & 1.37 \\
\hline \multirow{2}{*}{$\begin{array}{l}\text { Level of } \\
\text { Mother }\end{array}$} & 2011 & 0.42 & 13.93 & $0.00 *$ & 1.52 & 0.44 & 14.44 & $0.00 *$ & 1.54 \\
\hline & 2016 & 0.03 & 11.61 & $0.00 *$ & 1.03 & 0.02 & 5.15 & $0.02 *$ & 1.02 \\
\hline \multirow{3}{*}{$\begin{array}{l}\text { Education } \\
\text { Level of Father }\end{array}$} & 2003 & 0.24 & 10.89 & $0.00 *$ & 1.27 & 0.66 & 104.66 & $0.00 *$ & 1.93 \\
\hline & 2011 & 0.47 & 29.05 & $0.00 *$ & 1.59 & 0.44 & 23.06 & $0.00 *$ & 1.56 \\
\hline & 2016 & 0.01 & 6.98 & $0.01 *$ & 1.01 & 0.01 & 4.59 & $0.03 *$ & 1.01 \\
\hline \multirow{3}{*}{ Household Size } & 2003 & 0.03 & 0.61 & 0.43 & 1.03 & 0.06 & 3.87 & $0.05^{*}$ & 1.07 \\
\hline & 2011 & 0.07 & 1.93 & 0.16 & 1.08 & 0.31 & 37.18 & $0.00 *$ & 1.36 \\
\hline & 2016 & 0.09 & 15.25 & $0.00 *$ & 1.10 & 0.10 & 21.05 & $0.00 *$ & 1.11 \\
\hline Income (Annual & 2003 & 0.07 & 4.34 & $0.04 *$ & 1.07 & 0.17 & 36.40 & $0.00 *$ & 1.18 \\
\hline
\end{tabular}




\begin{tabular}{|c|c|c|c|c|c|c|c|c|c|}
\hline \multirow{2}{*}{$\begin{array}{l}\text { Independent } \\
\text { variables }\end{array}$} & \multirow{2}{*}{ Year } & \multicolumn{4}{|c|}{ Male } & \multicolumn{4}{|l|}{ Girl } \\
\hline & & $\beta$ & Wald & $p$ & $\operatorname{Exp}(B)$ & $\beta$ & Wald & $P$ & $\operatorname{Exp}(B)$ \\
\hline \multirow{2}{*}{$\begin{array}{l}\text { Income Per } \\
\text { Capita) }\end{array}$} & 2011 & 0.05 & 0.62 & 0.43 & 1.05 & 0.03 & 0.22 & 0.64 & 1.03 \\
\hline & 2016 & 0.11 & 5.48 & $0.02 *$ & 1.11 & 0.19 & 17.19 & $0.00 *$ & 1.20 \\
\hline Disability & 2011 & 1.31 & 7.90 & $0.01 *$ & 3.70 & 0.94 & 3.83 & $0.05^{*}$ & 2.56 \\
\hline \multirow[t]{2}{*}{ Status } & 2016 & 1.77 & 36.12 & $0.00 *$ & 5.88 & 1.72 & 21.44 & $0.00 *$ & 5.56 \\
\hline & 2003 & 0.54 & 5.29 & 0.02 & 1.72 & 2.20 & 105.16 & 0.00 & 9.01 \\
\hline \multirow[t]{2}{*}{ Constant } & 2011 & 2.13 & 4.23 & 0.04 & 8.43 & 1.49 & 2.07 & 0.15 & 4.43 \\
\hline & 2016 & 2.41 & 13.55 & 0.00 & 11.11 & 2.35 & 8.69 & 0.00 & 10.45 \\
\hline
\end{tabular}

$* \mathrm{p} \leq 0.05$

When the data analysis results of 2003 and 2011 are analyzed, boys and girls of secondary school age living in rural areas are more likely to be out of school than boys and girls living in urban areas. When Table 4 is analyzed, it is seen that while the settlement unit $(\beta=0.23 ; \operatorname{Exp}(B)=1.26))$ is a significant predictor $(p<0.05)$ in predicting the probability of being out of school for the secondary school age male population according to the data analysis results of 2003, it is not a significant predictor ( $p=0.49>0.05$ ) according to the 2011 data analysis results. According to 2003 data, when other independent variables in the model are kept under control, rural males are 1.26 times more likely to be out of school than urban males. In other words, $1.26 \%$ of the person of secondary school age males living in rural areas may be out of school, whereas one person of secondary school age males living in the city is out of school. In the 2011 data, there is no significant difference between the probability of being out of school for males living in urban and rural areas. In 2011 data, there is no significant difference between urban and rural males' probability of being out of school. The settlement unit is a significant variable $(p<0.05)$ in predicting the probability of being out of school for the female population of secondary school age according to 2003 $(\beta=0.29 ; \operatorname{Exp}(B)=1.33)$ and $2011(\beta=0.42 ; \operatorname{Exp}(B)=1.52)$ data. When other independent variables in the model are kept under control, rural girls are 1.33 times more likely to be out 
of school than urban girls for 2003 and 1.52 times more likely to be out of school for 2011 . In 2011, the settlement unit's effectiveness increased in keeping girls of secondary school age out of school. Place of residence is an effective variable to keep girls out of school rather than boys.

When the data analysis results of 2003, 2011, and 2016 regarding health assurance status in predicting to stay out of school according to gender discrimination are analyzed, secondary school age males without health assurance are more likely to be out of school than males with health assurance. When Table 4 is analyzed, it is seen that according to $2003(\beta=0.50 ; \operatorname{Exp}(B)=1.65) ; 2011(\beta=0.36 ; \operatorname{Exp}(B)=1.44)$ and $2016(\beta=0.04 ; \operatorname{Exp}(B)=$ 1.03) data, Health assurance (compulsory and optional insured; green card; no health assurance) is a significant variable $(p \leq 0.05)$ in predicting the exclusion of male population at secondary school age. The probability of being out of school for males of secondary school age without health assurance compared to males with a green card is 1.65 times for 2003; it is 1.44 times more for 2011 and 1.03 times for 2016. The probability of a male with a Green Card of secondary age to be out of school is 1.65 times for 2003 compared to males with a compulsory and optional insurance; it is 1.44 times higher for 2011 and 1.03 times for 2016.

While health insurance is not significant in predicting the exclusion of secondary school age girls from school according to 2016 data, it is a significant predictor according to 2003 and 2011 data. According to these years, girls of secondary school age who do not have health assurance are more likely to be out of school than girls with health assurance. In Table 4, according to the data of $2003(\beta=0.53 ; \operatorname{Exp}(B)=1.71), 2011(\beta=0.34 ; \operatorname{Exp}(B)=$ 1.41) and $2016(\beta=0.02 ; \operatorname{Exp}(B)=1.02)$, it is seen that health assurance is a significant variable $(p \leq 0.05)$ in predicting the exclusion of girls at secondary school age from school. The probability of being out of school for girls of secondary school age without health assurance compared to girls with a green card is 1.71 times for 2003, 1.41 times more in 2011, and 1.02 times for 2016. The decrease in health assurance (compulsory and optional insured; green card; no health assurance) increases the probability of being out of school. Secondary school-age boys and girls without health assurance are more likely to be out of school than their fellows with a green card.

Similarly, boys and girls with green cards are more likely to be out of school than their fellows with compulsory and optional insurance. Health assurance is an effective 
variable in the exclusion of girls and boys of secondary school age. However, except for 2003 data, it is seen that it is more effective, especially for boys, to stay out of school.

When data analysis results of 2003, 2011, and 2016 regarding the status of mother's education level in predicting to stay out of school according to gender discrimination are analyzed, it is seen that secondary school-age boys and girls with low mother's education level are more likely to be out of school than their fellows with high mother's education level. When Table 4 is analyzed, it is seen that the education level of the mother is a significant variable $(p \leq 0.05)$ in predicting the exclusion of male population of secondary school age for all three years, according to the data of $2003(\beta=0.47 ; \operatorname{Exp}(B)=1.60), 2011$ $(\beta=0.42 ; \operatorname{Exp}(B)=1.52)$ and $2016 \beta=0.03 ; \operatorname{Exp}(B)=1.03)$. A one-unit decrease in mother's education level (higher education grade, high school or equivalent school graduate, primary school graduate, primary school graduate, not graduate) increases the likelihood of secondary school age males being out of school 1.60 times for 2003; 1.52 times for 2011 and 1.03 times for 2016. In other words, in the secondary school-age population, the probability of being out of school is 1.60 times in 2003 for men whose mothers are primary school graduates compared to males whose mothers are primary education graduates. It is 1.52 times more for 2011 and 1.03 times for 2016. When Table 4 is analyzed, it is seen that the education level of the mother is a significant variable $(p \leq 0.05)$ in predicting the exclusion of the girl population of secondary school age for all three years, according to the data of $2003(\beta=0.31 ; \operatorname{Exp}(B)=1.37), 2011(\beta=0.44 ; \operatorname{Exp}(B)=1.54)$ and $2016 \beta=0.02 ; \operatorname{Exp}$ $(B)=1.02)$. A one-unit decrease in mother's education level increases the likelihood of secondary school age girls being out of school 1.37 times for 2003; 1.54 times for 2011, and 1.02 times for 2016. So in the secondary school-age population, the probability of being out of school is 1.37 times for 2003 for girls whose mothers are not graduates than girls whose mothers are primary school graduates. It is 1.54 times more for 2011 and 1.02 times for 2016. The mother's education level is an effective variable that causes more boys than girls to stay out of school, except in 2003.

When data analysis results of 2003, 2011, and 2016 regarding the status of father's education level in predicting to stay out of school according to gender discrimination are analyzed, it is seen that secondary school-age boys and girls with low father 's education level are more likely to be out of school than their fellows with high father's education level. When Table 4 is analyzed, it is seen that father's education level is a significant variable $(p \leq 0.05)$ in predicting the exclusion of the male population of secondary school age 
according to the data of $2003(\beta=0.24 ; \operatorname{Exp}(\mathrm{B})=1.27), 2011(\beta=0.47 ; \operatorname{Exp}(\mathrm{B})=1.59)$ and $2016(\beta=0.01 ; \operatorname{Exp}(B)=1.01)$. A one-unit decrease in father's education level increases the likelihood of secondary school age males being out of school 1.27 times for 2003, 1.59 times for 2011, and 1.01 times for 2016. So, in the secondary school-age population, the probability of being out of school is 1.27 times for 2003 for boys whose fathers are high school or equivalent school graduates compared to males whose fathers are higher education graduates. It is 1.59 times more for 2011 and 1.01 times for 2016. When Table 4 is analyzed, it is seen that the education level of the father is a significant variable $(p \leq 0.05)$ in predicting the exclusion of girl population of secondary school age for all three years, according to the data of $2003(\beta=0.66 ; \operatorname{Exp}(B)=1.93), 2011(\beta=0.44 ; \operatorname{Exp}(B)=1.56)$ and $2016(\beta=0.01 ; \operatorname{Exp}$ $(B)=1.01)$. A one-unit decrease in father's education level increases the likelihood of secondary school age girls being out of school 1.93 times for 2003, 1.56 times for 2011, and 1.01 times for 2016 . So, in the secondary school-age population, the probability of being out of school is 1.93 times for 2003 for girls whose fathers are not graduate than girls whose fathers are primary school graduates. It is 1.56 times more for 2011 and 1.01 times for 2016. It is seen that secondary school-age boys and girls with a high father's education level are less likely to be out of school than their fellows with a low father's education level, as the education level of the father increases, the probability of being out of school decreases. Father's education level is an effective variable that caused more girls than boys to stay out of school in 2003.

When data analysis results of 2003, 2011, and 2016 regarding the status of household size in predicting to stay out of school according to gender discrimination are analyzed, it is seen that secondary school-age boys and girls with a small household size are more likely to be out of school than their fellows with high household size. When Table 4 is analyzed, it is seen that household size is not a significant variable $(\mathrm{p}=0.43>0.05)$ in predicting the exclusion of the secondary school age's male population according to the data of 2003 and 2011. However, it is a significant variable $(p \leq 0.05)$ according to the data of $2016(\beta=0.09 ; \operatorname{Exp}(B)=1.10)$. While one -unit increase in household size (three or less "1 “; four persons " 2 "; five persons " 3 "; six persons " 4 "; seven and eight persons "5 "and nine persons or more " 6 ") does not affect the probability of secondary school age boys in 2003 and 2011, it increases this probability 1.10 times for 2016. When Table 4 is analyzed, it is seen that household size is a significant variable $(p \leq 0.05)$ in predicting the exclusion of girl population of secondary school age for all three years, according to the data of 2003 
$(\beta=0.06 ; \operatorname{Exp}(B)=1.07), 2011(\beta=0.31 ; \operatorname{Exp}(B)=1.36)$ and $2016(\beta=0.10 ; \operatorname{Exp}(B)=1.11)$.

A one-unit increase in household size increases the likelihood of girls of secondary school age being out of school 1.07 times for 2003, 1.36 times for 2011, and 1.11 times for 2016 . The number of household members especially affects the probability of exclusion of girls.

When data analysis results of 2003 and 2016 regarding the status of annual income per capita in predicting to stay out of school according to gender discrimination are analyzed, it is seen that secondary school-age boys and girls with low annual income per capita are more likely to be out of school than their fellows with high annual income per capita. Annual income per capita does not affect boys' and girls' probability of being out of school for 2011. When Table 4 is analyzed, it is seen that annual income per capita is a significant variable in predicting the exclusion of the male population of the secondary school age according to the data of $2003(\beta=0.07 ; \operatorname{Exp}(B)=1.07 ; p=0.04<0.05)$ and 2016 $(\beta=0.11 ; \operatorname{Exp}(B)=1.11 ; \mathrm{p}=0.02<0.05)$. However, it is not a significant variable $(\mathrm{p}=0.43>0.05)$ according to the data of $2011(\beta=0.01 ; \operatorname{Exp}(B)=1.01)$. A one-unit decrease in annual income per capita increases the likelihood of secondary school age males being out of school 1.07 times for 2003 and 1.11 times for 2016. In the population of secondary school age, males whose annual income per capita increases are less likely to be out of school. When Table 4 is analyzed, it is seen that annual income per capita is significant in predicting the exclusion of girls at the secondary school age according to the data of $2003(\beta=0.17$; $\operatorname{Exp}(B)=1.18 ; p=0.00<0.05)$ and $2016(\beta=0.19 ; \operatorname{Exp}(B)=1.20 ; \mathrm{p}=0.00<0.05)$. However, it is not a significant variable ( $\mathrm{p}=0.64>0.05$ ) according to the data of 2011 .

A one-unit decrease in annual income per capita increases the likelihood of secondary school age girls being out of school 1.18 times for 2003 and 1.20 times for 2016 . In the population of secondary school age girls whose annual income per capita increases are less likely to be out of school as the annual income per capita decreases, the probability of being out of school increases. Annual income per capita is a significant variable that affects girls' exclusion from school rather than boys. The impact of annual income per capita on the probability of being out of school increased from 2003 to 2016.

When data analysis results of 2011 and 2016 regarding the status of Disability Status in predicting to stay out of school according to gender discrimination are analyzed, it is seen that secondary school-age boys and girls without disabilities are less likely to be out of school than their fellows with disabilities. When Table 4 is analyzed, it is seen that disability 
status is a significant variable $(p \leq 0.05)$ in predicting the exclusion of disabled males of secondary school age according to the data of $2011(\beta=1.31 ; \operatorname{Exp}(B)=3.70)$ and 2016 $(\beta=1.77 ; \operatorname{Exp}(B)=5.88)$. Secondary school-age disabled males are 3.70 times more likely to be out of school than non-disabled males in 2011; they are 5.88 more likely to be out of school than non -disabled males in 2016. Disability status increases the probability of being out of school for males. When Table 4 is analyzed, it is seen that disability status is a significant variable $(p \leq 0.05)$ in predicting the exclusion of girls of secondary school age according to data of $2011(\beta=0.94 ; \operatorname{Exp}(B)=2.56)$ and $2016(\beta=1.72 ; \operatorname{Exp}(B)=5.56)$. Secondary school-age girls with disabilities are 2.56 times more likely to be out of school than non-disabled girls in 2011, and likewise, they are 5.56 times more likely to be out of school than their fellows without disabilities in 2016. The more disability among girls, the more likely they are to be out of school. Boys and girls with disabilities in secondary education are more likely to be out of school than their fellows without disabilities. When the data of 2011 and 2016 are compared, it is understood that in the secondary school-age population, the probability of staying out of school for people with disabilities more than doubled rather than decreasing and that the probability of staying out of school for disabled boys increased more than disabled girls.

\section{Discussion and Conclusion}

After analyzing the data, it is seen that the leading individual variables that are effective in staying out of school are disability status and gender variables. Girls are more likely to be out of school than boys in all 2011, 2003, and 2016 data. Disabled girls who live in the rural area; who have no social security; who have low father and mother education levels: and who are also in poor and crowded families are most likely to be out of school. Disabled girls who live in the rural area; who have no social security; who have low father and mother education levels; and who are in crowded and low-income families are most likely to be out of school.

In the analyzes, it was understood that disability status was the highest predictor of exclusion from school. People with disabilities are 2.74 and 5.56 times more likely to be out of school than non -disabled people, respectively, in 2011 and 2016. In many areas emphasized in the United Nations Convention on Disability Rights, all kinds of discrimination against children are thought to be effective in this situation. In the examples of the developed countries, children with disabilities are enrolled in mainstream education 
when conditions permit, and special education services are provided free of charge to children that experts determine. In Turkey, disabled children can stay out of school because of some factors such as primary schools are not sufficient in terms of physical facilities and number of teachers for disabled children, only a small number of people can benefit from special education services compared to other countries, and also these special education services are paid (Genç \& Orhan, 2015). As Çağlar (2009) pointed out, this may also be because families, who do not expect a future, academic benefit or success from their disabled children, tend not to send their children to school unless it is compulsory and what is more as expenses of transportation, nutrition and similar needs of disabled children are much is another reason for families not to send their disabled children to school. Likewise, in studies regarding children at risk of being excluded from school, disabled children come first (Hillman, 2014).

When the literature is examined, it is emphasized that girls stay out of school against their will due to reasons such as girls' entering adult roles at an early age (helping mother with household chores and looking after their siblings) (Adıgüzel, 2013; Hoşgörür \& Polat 2015; Küçüker, 2018; Tunç, 2009; UNICEF, 2017); girls being forced into early marriage due to early puberty (Adigüzel, 2013; Dilli, 2006; Tunç, 2009); the thought that only being literate is enough for girls as their husbands take care of them when they get married (Dilli, 2006; Özdemir, Erkan, Karip, Sezgin and Şirin, 2010; Tunç, 2009); traditional prejudices of families that keep boys ahead of girls (Bakış, Levent, İnsel \& Polat, 2009; Özdemir et al., 2010; Tunç, 2009); condemnation of parents by relatives and family elders (Adigüzel, 2013, Tunç, 2009); concern that girls will violate traditional values and ethical problems (Tunç, 2009) and conservative families are making coeducation a a problem (Bora, 2012; Tunç, 2009). These reasons support the findings of the study. It has been understood that gender perceptions differ according to the residential area, and girls and boys living in rural areas are more negatively affected than their peers in the city. This situation suggests that rural families have a low education level; the vast majority of them make their living from agriculture and animal husbandry, and they have a more religiously conservative mindset. According to Kara and Gürhan (2013), the religious institution, where inequality is reproduced, functions as a "divine opportunity "in naturalizing gender inequality.

It has been found that there is a significant difference between the secondary schoolage population living in rural and urban areas in their probability of being out of school and especially rural children stay out of school more than urban children. According to Kocakurt 
(2016), in all levels of education in Turkey, especially at the high school level, rural areas are the places with the least number of schools, teachers, and classrooms; high birth rates in rural areas; the rural people are on the poverty line because of the low socio-economic development level; children being employed inside and /or outside the home as the livelihood of the rural population depends on agriculture and animal husbandry can be emphasized as some of the most important reasons for the difference between settlements. Also, as Soydan (2015) emphasized, the problems experienced in keeping qualified teachers in these regions due to the difficulty of creating appropriate educational and vital opportunities for teachers working in the rural areas are among the most prominent reasons for not establishing a qualified education system in the rural areas. However, this research results do not support the finding of Gümüş (2014) that the rural-urban distinction does not significantly affect children's school attendance after various individual and societal variables are taken under control. Gümüş (2014) emphasized that the differences in school participation of children in rural and urban areas did not only stem from their location but also inequalities at the household and society level.

Household size and family structure have a determining effect on the rate of household member's utilization of income and other resources. According to the research data, the larger the household size, the higher the probability of being out of school. Parents with unfavorable socio-economic conditions have problems in financing their children's educational needs and can not take care of their children individually because of a large number of children (Soydan 2015). The findings of the study support the findings of previous studies (Beatty, Neisser, Trent \& Heubert, 2001; Cemalcılar, Gökşen \& Çelik, 2012; Gökşen, Cemalcılar \& Gürlesel, 2006; Gümüş, 2014; MEB, 2013; Özdemir et al., 2010; Şimşek, 2011). However, the findings were not consistent with Mike, Nakajjo, and Isoke (2016)'findings that children living in larger households were less likely to drop out than children living in smaller households. The relationships were statistically significant. This difference is thought to be due to the state support given to large families. Having older siblings who bring income to the home can also reduce the likelihood of being out of school. As the size of the household increases, the possibility of creating a quiet, warm and undisturbed studying environment for children to read and study decreases. As the household size increases, individuals' average consumption expenditure decreases, and the poorest families first cut their education expenditures. 
Parents' education level is an effective variable in predicting exclusion from school; as mother and father's education level increases, the probability of being out of school decreases. The findings of the study support the findings of previous studies (Bakış et al., 2009; Bora, 2012; Gökşen et al., 2006; Gümüş, 2014; Hoşgörür \& Polat, 2015; Özbaş, 2012. Pehlivan, 2006). Educated parents are more likely to monitor their children's academic development and supervise and help their children with their academic work more effectively by spending more time with their children than uneducated parents. Parents with a high level of education strive to create rich reading resources and environments in their homes in a way that affects their children's success constructively. Besides, they have higher expectations from their children (Gülleroğlu, Demir \& Demirtaşl1, 2014). Parents who have high educational expectations from their children inspire their children to participate in extracurricular activities; communicate more with teachers, and hence good relations with teachers increase the likelihood of motivation of children and parallel to this, teachers facilitate cooperation with parents in overcoming problems with students (Cui, 2014). Educated parents are more aware of the potential benefits of their children 's education. Their children are more likely to have access to the information and social Networks that they need to engage in activities that bring high income. Besides, higher parental education makes it easier for parents to get to know their children better. It influences constructively by transforming relationships with their children into a healthier and more effective way, according to Özel and Zelyurt (2016). Less-educated parents place more emphasis on academic achievement reflected in high scores in measured tests than more abstract and subjective ways of assessing student performance (for example, by student portfolios), according to Schneider, Marschall, Teske, and Roch (1998). Because strong performance in tests is associated with access to good colleges and good jobs for them. Parents with less education tend to want more discipline in the classroom.

Health Assurance (compulsory and optional insured, with a green card, no insurance) is an effective variable in predicting school exclusion; as health assurance decreases, the probability of being out of school increases. People with a green card and people without any insurance are more out of school than compulsory and optional insured people; similarly, those who do not have any insurance are more out of school than people with green cards. Information on the family's social security provides clues about the family's monthly income and whether they work in formal/informal jobs. For example, the green card is given to families with no social security, and are deprived of insurance and have a 
low monthly income. So the treatment and health expenses of these families are covered by the state. However, there is neither a green card nor a health assurance for families whose parents do not work (can not work)or who work informally with a wage lower than the minimum wage, and hence treatment and health expenses of the individuals in this family are not financed by the state. Health assurance stands out as an important variable regarding the living conditions of the families.

The status of annual income per capita variable in predicting to stay out of school differs by years. According to 2003 and 2016 data, the annual income per capita variable according to gender discrimination is a significant variable in predicting the exclusion of male and female population of secondary school age. Still, it is not a significant variable according to 2011 data. Secondary school-age boys and girls with high annual income per capita are less likely to be out of school than their fellows with low annual income per capita as the annual income per capita decreases - the probability of being out of school increases. The rise in income is more of an effective factor for women to continue education. It is supported by the findings in Tomul (2008)'s study that the increase in income is most effective in the continuation of education for women aged 18-23. There is a positive relationship between monthly household income per capita and enrollment. Although this relationship is positive, it differs by gender. While this relationship between income and enrollment in school is linear for young males in Thailand, it may be inverted U-shaped for young females (Tharmmapornphilas, 2013). Low income refers to the economic dimension of poverty.

Extreme poverty is a factor that reduces school attendance because children who struggle with hunger at some point in their lives are less likely to go to school (Cardoso \& Verner, 2006). The main reason for children being excluded from school is the lack of sufficient funds. The main obstacle is the decrease in the household income due to the loss of income of the student (World Bank, 2005). Young people with low income do not have higher education expectations and hence evaluate the cost to be incurred to continue secondary education in terms of finding a job and salary earnings that this education will bring and so they may stay out of school when they find any job opportunity, even in informal sectors (Education Reform Initiative, 2009). Due to the inadequacy of the family's economic situation, entering the labor market with the parents to earn money and contribute to the family economy or their increased responsibilities in housework may cause children to stay out of school at an early age (Bakış et al., 2009; Karadağ \& Balkar, 2015; Özdemir et 
al., 2010). The income variable is also effective in exclusion from school due to school factors. Rich people can enroll/ transfer their children to qualified schools, but the poor do not have such opportunities (Yolcu, 2011). The effect of annual income per capita in predicting exclusion from school may have reduced as the period of compulsory education increases to 12 years, and low-income families start to give importance to their children's education like rich people.

Socio-economic variables according to gender discrimination (settlement unit, health assurance, disability status, education level of father and mother, household size, and annual income per capita) are significant predictors in the analysis of exclusion from school. While the predictive effect of the disability status variable increased, it was found that although other variables were still significant predictors, their effect rates decreased over the years. This situation stems from the fact that those who are not enrolled in a formal education institution at the secondary education level due to the increase in the duration of compulsory education; and students who are absent or students who make grade repetition twice are automatically accepted as open high school students in the e-school system.

\section{Suggestions}

Based on the results of the research, the following policy suggestions can be presented

1. Educational practices that consider the differences of children with disabilities should be increased; Parents of disabled children should be made aware of public support for disabled people, and these parents should be directed to empower their children.

2. Confronting the existing economic system should become the goal of our society. The state should take measures to eliminate the influence of socio-economic characteristics in access to education.

3. Regardless of parents' social security (no insurance, green card, compulsory and optional insurance), everyone should have equal health coverage.

4. Scholarship applications and schooling campaigns of the state and non-governmental organizations contribute to the continuation of education of many children, although in part; financial aid should be given to the poor families to meet the educational needs of the child, and projects should be developed to convince conservative families who do not send their girls to school.

5. Considering the effect of parents' education level on the education period of the children, the studies to increase adult literacy should be done in the whole country; and 
efforts should be made to increase the quality and quantity of relations between the family and the school.

6. By referring to religious references, politicians should not encourage families to have more children by stating that "each family should have at least three children" and "families will be given financial aid per child."

7. Since education is a human right, necessary school buildings should be built where needed, and qualification differences between schools should be removed. Rights should not be sacrificed for cost-benefit analysis. The number of secondary education schools should be increased, especially in rural areas.

8. The fact that some variables are not measured in the data of TUIK (for example, settlement unit-rural-urban) prevents the comparison of these variables. Therefore, the basic variables should be measured in the surveys that TUIK conducts every year.

9. In order to compare exclusion from school and living conditions of different nations, beliefs, and sexual identities, these variables should also be included in TUIK data.

10. Ministry of Education should create a data repository of gender, age, sexual identity, nation, religious belief, school type, place of residence, and so on for failure, absenteeism, suspension from school, and school exclusion.

\section{Research Suggestions}

The application suggestions developed based on the results obtained in this research, and that can contribute to the researchers and applications that are to be made are listed below.

1. Future researches can be conducted based on data from TUIK's income and living conditions surveys.

2. This research has been conducted with children who are out of school at the secondary education level. Future researches can be conducted with children/young people with different educational levels.

3. With the change is known as $4+4+4$ in public, 12 -year compulsory gradual education started as of the 2012-2013 academic year (Primary Education and education law and law on making changes in some laws, 2012). It can be researched how this radical change in the education system effect dropouts.

4. Countries with different economic systems can be compared in terms of staying out of school. 
5. Staying out of school, absenteeism, and grade repetition situations in public and private schools can be studied by comparing.

6. More researches should be conducted on how education policies and school climates affect absenteeism, failure, grade repetition, and staying out of school.

7. Our country receives immigration from different countries, and the number of refugees in our country is increasing. To guide the policies that will ensure the integration of asylum seekers into society and take part in education, field research covering the social and educational problems of refugees and refugee children can be planned.

Acknowledgment: Thanks to the State Statistical Institute and Turkey Statistical Agency employees for providing household budget survey microdata.

\section{Ethical Approval:}

This study relies on Selman Almış's Ph.D. dissertation, which was supervised by the Kasım Karakütük, accepted on October 4, 2019, Ankara University Institute of Education Sciences, Ankara, Turkey. This study was carried out with the permission obtained with Sinop University Human Research Ethics Committee's decision, dated 12/07/2019 and numbered 2019-36. In order to obtain data suitable for research purposes, data was requested from TUIK. TUIK responded positively to the data request and delivered the relevant surveys for 2003-2013 by mail in the CD form. The survey data for 2016 has been made available as accessible in an electronic environment to the researcher with the decision dated 30/07/2018 and numbered 27964695-622.03-E.17240.

Conflict Interest: Authors have no conflict of interest to declare.

Authors Contributions: The authors have contributed equally to this paper. 


\section{References}

Adıgüzel, A. (2013). Kız çocuklarının okullulaşma engelleri ve çözüm önerileri (Şanlıurfa Örneği). EKEV Akademi Dergisi, 56(Yaz), 325-344.

Andrei, T., Teodorescu, D., \& Oancea, B. (2012). Quantitative Methods Used to Identify the Causes of School Dropout in EU Countries. Procedia - Social and Behavioral Sciences, 31, 188-192.

Bakış, O., Levent, H., İnsel, A. ve Polat, S. (2009). Türkiye'de eğitime erişimin belirleyicileri. İstanbul: Sabancı Üniversitesi Yayınları.

Battin-Pearson, S., Newcomb, M. D., Abbott, R. D., Hill, K. G., Catalano, R. F., \& Hawkins, J. D. (2000). Predictors of early high school dropout: a test of five theories. Journal of Educational Psychology, 92(3), 568-582. https://doi.org/10.1037/00220663.92.3.568

Beatty, A., Neisser, U., Trent, W. T., \& Heubert, J. P. (2001). Understanding dropouts: statistics, strategies, and high-stakes testing (A. Beatty, U. Neisser, W. T. Trent, \& J. P. Heubert, eds.). Washington, D.C.: National Research Council.

Berktold, J., Geis, S., \& Kaufman, P. (1998). Subsequent educational attainment of high school dropouts. Department of Education Office of Educational.. [Available online at: https://eric.ed.gov/?id=ED419900] Retrieved on May 2, 2017.

Birleşmiş Milletler (1949). Birleşmiş Milletler Evrensel Beyannamesi, [Çevrim içi: https://www.tbmm.gov.tr/komisyon/insanhaklari/pdf01/203-208.pdf], Erişim tarihi: 18.09.2016.

Blanden, J., \& Gregg, P. (2004). Family income and educational attainment: a review of approaches and evidence for Britain. Oxford Review of Economic Policy, 20(2), 245263. https://doi.org/10.1093/oxrep/grh014

Bora, V. (2012). Klz çocuklarının zorunlu ĕgitim sonrası ortaöğretime devam etmeme nedenleri. Yayınlanmamış Yüksek Lisans Tezi, Mehmet Akif Ersoy Üniversitesi, Burdur, Türkiye.

Bridgeland, J. M., Dilulio, J. J., \& Morison, K. B. (2006). The silent epidemic: Perspectives of high school dropouts. In Civic Enterprises. [Available online at: http://eric.ed.gov/?id=ED513444] Retrieved on January 26, 2016. 
Brunello, G. \& De Paola, M. (2013). The costs of early school leaving in Europe. IZA Journal of Labor Policy, 3(1), 1-31. [Available online at: http://www.izajolp.com/content/3/1/22], Retrieved on January 2, 2021.

Cardoso, A. R. ve Verner, D. (2006). School dropout and push-out factors in Brazil: The role of early parenthood, child labor, and poverty (No: 2515). Bonn. [Available online at: https://papers.ssrn.com/sol3/papers.cfm?abstract_id=975849], Retrieved on October 25, 2018.

Cemalcılar, Z., Gökşen, F. ve Çelik, Ç. (2012). Illköğretimde okulu terke neden olan demografik, sosyal ve çevresel faktörlerin belirlenmesi çalışması. TÜBİTAK SOBAG Projesi. (Proje No : 108K222).

Crosnoe, R., Mistry, R. S., \& Elder Jr, G. H. (2002). Economic disadvantage, family dynamics, and adolescent enrollment in higher education. Journal of Marriage and Family, 64(3), 690-702. https://doi.org/10.1111/j.1741-3737.2002.00690.x

Cui, M. (2014). Exploring explanatory individual related factors of high school dropout. Unpublished master's thesis. University at Buffalo, New York, United States.

Çağlar, S. (2009). Uluslararası hukuk ve Türk hukuk sisteminde engellilerin eğitim hakkı ve devlet yükümlülükleri. Yayınlanmamış Doktora Tezi. Marmara Üniversitesi, İstanbul, Türkiye.

Çelik, Ç. (2014). Okul terk’i politikleştirmek. Eleştirel Pedagoji Dergisi, 6(34), 12-17.

Dale, R. (2010). Early school leaving. lessons from research for policymakers (NESSE Report). [Available online at: http://www.nesse.fr/nesse/activities/reports/activities/reports/early-school-leavingreport], Retrieved on December 29, 2020.

Devlet İstatistik Enstitüsü (DİE) (2003). Hanehalkı bütçe anketi fert veri seti. Ankara: Devlet İstatistik Enstitüsü.

Dilli, C. (2006). Zorunlu eğitim çağında bulunan kız çocuklarının okula gitmeme nedenleri (Şırnak ili örneği). Yayınlanmamış Yüksek Lisans Tezi, Fırat Üniversitesi, Elazığ, Türkiye.

DİSK Araştırma Enstitüsü (2013). Çocuk işçiliği Raporu 2013 (Rapor No. 8). İstanbul: Türkiye Devrimci İşçi Sendikaları Konfederasyonu Araştırma Enstitüsü 
Dünya Bankası. (2005). Gençler için firsatları genişletmek ve yetkinlikler oluşturmak: Orta öğretim için yeni bir gündem. Washington, D.C.

Eğitim Reformu Girişimi. (2009). Ĕgitim İzleme Raporu 2009. İstanbul.

Eskicumalı, A. ve Önce, B. (2014). İlköğretim okullarında adrese dayalı kayıt sistemi ve eğitimde firsat eşitliği. İçinde N. S. Baykal, A. Ural ve Z. Alica (Eds.), Eleştirel Ĕ̈itim Seçkisi (pp. 289-303). Ankara: Pegem Akademi.

European Commission. (2005). Private household spending on education \& training. [Available online at: http://www.pedz.uni-mannheim.de/daten/edzb/gdbk/05/private_household_spend.pdf], Retrieved on April 29, 2019.

European Commission. (2009). Early school leaving [Available online at: https://ec.europa.eu/education/policies/school/early-school-leaving_en], Retrieved on December 30, 2020.

Genç, K. G. ve Orhan, S. (2015). Engellilere yönelik ülkemizdeki özel eğitim hizmet uygulamaları ve örnek ülke karşılaştırması. Sosyal Politika Çalışmaları Dergisi, $15(35 / 2), 115-146$.

Gökşen, F., Cemalcılar, Z. ve Gürlesel, C. F. (2006). Türkiye'de ilköğretim okullarında okulu terk ve izlenmesi ile önlenmesine yönelik politikalar. İstanbul: AÇEV

Gülleroğlu, H. D., Demir, S. B. ve Demirtaşl1, N. (2014). Türk öğrencilerinin PISA 20032006-2009 dönemlerindeki okuma becerilerini yordayan sosyoekonomik ve kültürel değişkenlerin araştırılması. Ankara Üniversitesi Eğitim Bilimleri Fakültesi Dergisi, $47(2), 201-222$.

Gümüş, S. (2014). The effects of community factors on school participation in Turkey: A multilevel analysis. International Review of Education, 60(1), 79-98.

Hayes, R. L., Nelson, J.-L., Tabin, M., Pearson, G., \& Worthy, C. (2002). Using schoolwide data to advocate for student success. Professional School Counseling, 6(2), 8694.

Helliwell, J. F. (2001). The contribution of human and social capital to sustained economic growth. [Available online at: http://www.oecd.org/innovation/research/1825902.pdf] Retrieved on October 27, 2015. 
Hillman, D. B. (2014). Using an early warning system to identify potential high school dropouts. Unpublished doctoral dissertation, University of Northern Colorado, Colorado, United States.

Hoşgörür, V. ve Polat, M. (2015). Ortaokul öğrencilerinin okula devamsızlık nedenleri (Söke ilçesi örneği). Muğla Sıtkı Koçman Üniversitesi Eğitim Fakültesi Dergisi, 1(2), $25-42$.

Huisman, J., \& Smits, J. (2015). Keeping children in school: Effects of household and context characteristics on school dropout in 363 districts of 30 developing countries. Sage Open, 5(4), 1-16. https://doi.org/10.1177/2158244015609666

İlköğretim ve eğitim kanunu ile bazı kanunlarda değişiklik yapılmasına dair kanun $(2012,11$ Nisan). Resmi Gazete (Sayı: 28261). [Erişim adresi: https://www.resmigazete.gov.tr/eskiler/2012/04/20120411-8.htm]

Kara, Z. ve Gürhan, N. (2013). Eşit/sizliğin tarafı olmak: Mardin'de toplumsal cinsiyet alg1s1. Bilim ve Toplum, 3(5), 65-92.

Karadağ, N. ve Balkar, B. (2015). Toplumsal kalkınmanın bir aracı olarak eğitim. Trakya Üniversitesi Sosyal Bilimler Dergisi, 17(1), 225-239.

Kavak, Y. ve Ekinci, C. E. (1994). Eğitimin Finansmanı Sorunu ve Maliyetlerin Azaltılmasına İlişkin Alternatif Stratejiler. Hacettepe Üniversitesi Eğitim Fakültesi Dergisi, 10, 65-72.

Kocakurt, S. Ö. (2016). Türkiye'de kırsal alanda okullaşma ve yetişkin nüfusun ĕ̆itim durumuna ilişkin bir analiz. Yayınlanmamış Yüksek Lisans Tezi, Ankara Üniversitesi, Ankara, Türkiye.

Köse, M. R. (2006). Aile sosyoekonomik ve demografik özellikleri ile okul ve özel dershanenin liselere giriş sınavına katılan öğrencilerin akademik başarıları üzerindeki etkileri. Eğitim Bilim Toplum Dergisi, 5(17), 46-77.

Küçüker, E. (2018). Kırsal kesimde yaşayan kız çocukların örgün ortaöğretimi terk etme nedenleri. Eğitim ve Bilim, 43(195), 97-117. [Çevrim içi: https://doi.org/10.15390/EB.2018.7537], Erişim Tarihi: 30.3.2019.

Machin, S., \& Vignoles, A. (2004). Educational inequality: the widening socio-economic gap. Fiscal Studies, 25(2), 107-128. 
MEB (2013), Ortaögrretimde sınıf tekrarl, okul terk sebepleri ve örgün eğitim dışında kalan çocuklar politika önerileri raporu. [Çevrim içi: https://www.meb.gov.tr/earged/unicef/S\%C4\%B1n\%C4\%B1f\%20Tekrar\%C4\%B1, \%200kul\%20Terki\%20Politika\%20Raporu.pdf], Erişim Tarihi: 21.09.2017.

MEB (2014). Milli Eğitim İstatistikleri Örgün Eğitim 2013/’14. Ankara: Milli Eğitim Bakanlığı (MEB).

Mertler, C. A. \& Reinhart, R. V. (2017). Advanced and multivariate statistical methods: Practical application and interpretation. New York: Taylor \& Francis.

Mike, I. O., Nakajjo, A., \& Isoke, D. (2016). Socio-economic determinants of primary school drop out: the logistic model analysis. African Journal of Economic Review, $4(1), 217-241$.

Moineddin, R., Matheson, F. I., \& Glazier, R. H. (2007). A simulation study of sample size for multilevel logistic regression models. BMC Medical Research Methodology, 7(1), $34-44$.

Organisation For Economic Co-Operation and Development (OECD). (2001). The wellbeing of nations: the role of human and social capital. [Available online at: http://www.oecd.org/edu/innovation-education/1870573.pdf], Retrieved on December 10, 2016.

Özbaş, M. (2012). Kız çocuklarının ortaöğretimde okullaşma oranlarına etki eden nedenlere ilişkin algıları. International Journal of New Trends in Arts, Sports \& Science Education, 1(4), 60-71. [Available online at: http://www.iojpe.org/ojs/index.php/IJTASE/article/view/156], Retrieved on April 23, 2015.

Özdamar, K. (2004). Paket programlar ve istatistiksel veri analizleri. Eskişehir: Kaan Kitabevi.

Özdemir, S., Erkan, S., Karip, E., Sezgin, F. ve Şirin, H. (2010). İlkögrretim okulu ögrencilerinin okulu terk etme nedenleri ve çözüm önerileri. TÜBİTAK Projesi, (107K453).

Özel, E. ve Zelyurt, H. (2016). Anne baba eğitiminin aile çocuk ilişkilerine etkisi. Sosyal Politika Çalışmaları Dergisi, 16(36), 9-34. 
Özer, A., Gençtanırım, D. ve Ergene, T. (2011). Türk lise öğrencilerine okul terkinin yordanması: Aracı ve etkileşim değişkenleri ile bir model testi. Eğitim ve Bilim, $36(161), 302-317$.

Pehlivan, Z. (2006). Resmi genel liselerde ögrenci devamsızlı̆̆l ve buna dönük okul yönetimi politikaları (Ankara İli Örneği). Yayınlanmamış Yüksek Lisans Tezi, Ankara Üniversitesi, Ankara.

Rankin, B. H., \& Aytaç, I. A. (2006). Gender inequality in schooling: the case of Turkey. Sociology of Education, 79(1), 25-43. https://doi.org/10.1177/003804070607900102

Rosenthal, B. S. (1998). Non-school correlates of dropout: an integrative review of the literature. Children and Youth Services Review, 20(5), 413-433. [Available online at: https://doi.org/10.1016/S0190-7409(98)00015-2], Retrieved on April 2, 2016.

Rouse, C. E. (2007). Consequences for the labor market. In C. R. Belfield \& H. M. Levin (Eds.), The Price We Pay (pp. 99-124). Washington, D.C.: Brookings Institution Press.

Rumberger, R. W. (1987). High school dropouts: a review of issues and evidence. Review of Educational Research, 57(2), 101-121. [Available online at: https://doi.org/10.3102/00346543057002101], Retrieved on May 22, 2018

Rumberger, R. W. (2001). Why students drop out of school and what can be done. Dropouts in America: How severe is the problem? What do we know about intervention and prevention? 1-45. [Available online at: https://doi.org/10.1016/0047-2352(73)900160], Retrieved on July 18, 2017.

Schneider, M., Marschall, M., Teske, P., \& Roch, C. (1998). School choice and culture wars in the classroom: What different parents seek from education. Social Science Quarterly, 79(3), 489-501.

Smith, E. (2017). İkincil Veri. In J. Arthur, M. Waring, R. Coe ve L. V. Hedges (Eds.), \& I. Tekin (Trans.), Eğitimde Araştırma Yöntemleri ve Metodolojileri (pp. 205-213). Ankara: Anı Yayıncılık.

Smits, J., \& Hoşgör, A. G. (2006). Effects of family background characteristics on educational participation in Turkey. International Journal of Educational Development, 26(5), 545-560. https://doi.org/10.1016/j.ijedudev.2006.02.002 
Soydan, T. (2015). Being a teacher in the East of Turkey. Journal for Critical Education Policy Studies, 13(1), 173-209.

Şimşek, H. (2011). Lise öğrencilerinde okulu bırakma eğilimi ve nedenleri. Eğitim Bilimleri Araştırmaları Dergisi, 1(2), 27-47.

Şirin, H., Özdemir, S. ve Sezgin, F. (2009). Okulu terk eden çocukların ve velilerin okul terkine ilişkin görüşleri: Nitel bir inceleme. XVIII. Ulusal Eğitim Bilimleri Kurultayl, $1-3$.

Tabachnick, B. G. ve Fidell, L. S. (2015). Çok değişkenli istatistiklerin kullanımı (M. Baloğlu, Çev.). Ankara: Nobel Akademik Yayıncılık.

Tansel, A. (2002). Determinants of school attainment of boys and girls in Turkey: Individual, household and community factors. Economics of Education Review, 21(5), 455-470. [Available online at: https://doi.org/10.1016/S0272-7757(01)000280], Retrieved on March 1, 2017

Taş, A., Selvitopu, A., Bora, V. ve Demirkaya, Y. (2013). Meslek Lisesi öğrencilerinin okul terk nedenleri. Kuram ve Uygulamada Eğitim Bilimleri, 13(3), 1561-1565.

Taylı, A. (2008). Eğitim sisteminde önemli bir sorun: Okulu bırakma. Türk Psikolojik Danışma ve Rehberlik Dergisi, 3(30), 89-101.

Tharmmapornphilas, R. (2013). Impact of household factors on youth's school decisions in Thailand. Economics of Education Review, 37(0), 258-272. doi:http://dx.doi.org/10.1016/j.econedurev.2013.09.007

Tilak, J. B. (2002). Determinants of household expenditure on education in rural India (Working Paper Series No. 88). New Delhi: National Council of Applied Economic Research.

Tomul, E. (2007). Türkiye'de eğitime katılım üzerinde gelirin etkisi. Pamukkale Üniversitesi Eğitim Fakültesi Dergisi, 2(22), 122-131. [Çevrim içi: http://dergipark.ulakbim.gov.tr/pauefd/article/download/5000056207/5000053416], Erişim tarihi: 14.12.2017.

Tomul, E. (2008). The relative effects of family socio-economic characteristics on participation in education in Turkey. Eurasian Journal of Educational Research, $8(30), 153-168$. 
Türkiye Büyük Millet Meclisi (1982). Türkiye Cumhuriyeti Anayasası, [Çevrim içi: https://www.tbmm.gov.tr/develop/owa/tc_anayasasi.maddeler?p3=42], Erişim Tarihi: 24.05 .2016

Türkiye İstatistik Kurumu (TÜİK). (2009). Hanehalkı bütçe araştırması, tüketim harcamaları 2009. [Çevrim içi: http://www.tuik.gov.tr/IcerikGetir.do?istab_id=33], Erişim tarihi: 14.12.2017.

TÜİK. (2011). Hanehalkı bütçe anketi fert veri seti. Ankara: Türkiye İstatistik Kurumu.

TÜİK. (2016). Hanehalkı bütçe anketi fert veri seti. Ankara: Türkiye İstatistik Kurumu.

Tunç, A. I. (2009). Kız çocuklarının okula gitmeme nedenleri (Van ili örneği). Yüzüncü Yıl Üniversitesi Ë̆itim Fakültesi Dergisi, VI(1), 237-269.

UNESCO (2015). Gender and EFA 2000-2015: Gender summary. [Available online at: https://unesdoc.unesco.org/ark:/48223/pf0000234809], Retrieved on May 2, 2017.

United Nations International Children's Emergency Fund (UNICEF) (2004). Çocuk haklarına dair sözleşme. [Çevrim içi: https://www.unicefturk.org/public/uploads/files/UNICEF_CocukHaklarinaDairSozle sme.pdf], Erişim tarihi: 12.10.2016.

UNICEF. (2014). The state of the World's children 2014 -Every child counts. [Çevrim içi: www.unicef.org/sowc2014/numbers], Retrieved on November 10, 2017.

UNICEF. (2017). Türkiye'de çocukların durumu analizi 2011. [Çevrim içi: http://abdigm.meb.gov.tr/projeler/ois/egitim/032.pdf], Erişim tarihi: 29.04.2019.

Uysal, A. (2008). Okulu bırakma sorunu üzerine tartışmalar: çevresel faktörler. Milli Eğitim, (178), 139-149.

Ünal, L. I., Özsoy, S., Yıldız, A., Güngör, S., Çankaya, D. ve Aylar, E. (2010). Ĕgitimde Toplumsal Ayrışma. Ankara: Ankara Üniversitesi Basımevi.

Vassiliou, A. (2011). Opening statement on education benchmark report. [Available online at: http://europa.eu/rapid/press-release_SPEECH-11-288_en.pdf], Retrieved on December 7, 2018.

Yolcu, H. (2011). Hanehalkının eğitim harcamalarını etkileyen etmenler: Kuramsal bir çalışma. Mehmet Akif Ersoy Üniversitesi Sosyal Bilimler Enstitüsü Dergisi, 3(5), 12 - 
35. Çevrim içi: https://dergipark.org.tr/en/download/article-file/181764], Erişim tarihi: 02.01.2021.

Yüksel-Kaptanoğlu, İ. ve Ergöçmen, B. (2012). Çocuk gelin olmaya giden yol. Sosyoloji Araştırmaları Dergisi, 15(2), 129-161. 